\title{
LUCIANA PENA DE OLIVEIRA
}

TRATABILIDADE DE SOLOS TROPICAIS CONTAMINADOS POR RESÍDUOS DA INDÚSTRIA DE REVESTIMENTOS CERÂMICOS

Dissertação apresentada à Escola Politécnica da Universidade de São Paulo para obtenção do

Título de Mestre em Engenharia. 


\section{LUCIANA PENA DE OLIVEIRA}

TRATABILIDADE DE SOLOS TROPICAIS CONTAMINADOS POR RESÍDUOS DA INDÚSTRIA DE REVESTIMENTOS CERÂMICOS

Dissertação apresentada à Escola Politécnica da Universidade de São Paulo para obtenção do Título de Mestre em Engenharia.

Área de Concentração:

Engenharia Hidráulica

Orientador:

Prof $^{a}$ Dr $^{a}$ Dione Mari Morita 
Este exemplar foi revisado e alterado em relação à versão original, sob responsabilidade única do autor e com a anuência de seu orientador.

São Paulo, 17 de novembro de 2006.

Assinatura do autor

Assinatura do orientador

FICHA CATALOGRÁFICA

Oliveira, Luciana Pena de

Tratabilidade de solos tropicais contaminados por resíduos da indústria de revestimentos cerâmicos / L.P. de Oliveira. -ed.rev. -- São Paulo, 2006.

p. 109

Dissertação (Mestrado) - Escola Politécnica da Universidade de São Paulo. Departamento de Engenharia Hidráulica e Sanitária.

1.Tratamento do solo 2.Metais 3 .Indústria da cerâmica e da argila I.Universidade de São Paulo. Escola Politécnica. Departamento de Engenharia Hidráulica e Sanitária Il.t. 
Dedico este trabalho de pesquisa à minha amada mãe $e$ à memória dos meus queridos avós Lúcia e Orestes Lui. 


\section{AGRADECIMENTOS}

Agradeço à $\operatorname{Prof}^{a} \operatorname{Dr}^{\mathrm{a}}$ Dione Mari Morita pela precisa orientação e apoio a todas as etapas deste trabalho.

À FAPESP - Fundação de Amparo à Pesquisa do Estado de São Paulo pelo financiamento da parte experimental desta pesquisa.

Às professoras Maria Eugênia Gimenez Boscov e Irma Rivera pelas sugestões dadas no Exame de Qualificação.

Ao $\operatorname{Prof}^{\circ} \operatorname{Dr}^{\circ}$ José Eduardo Bevilacqua pelo auxílio na definição da metodologia.

Ao colega André Negrão de Moura pelo fornecimento de dados fundamentais à realização deste trabalho.

Ao apoio dado pelas equipes do Laboratório de Saneamento e da Secretaria do Departamento de Hidráulica - PHD da Escola Politécnica.

Ao Antonio e ao Joaquim, técnicos do Laboratório de Solos do Departamento de Estruturas e Fundações - PEF da Escola Politécnica, pelo empréstimo de materiais e execução do ensaio granulométrico.

À minha amada mãe pelo apoio incondicional nos bons e maus momentos dessa jornada.

Aos meus amigos Carlos Galan e Luís Eduardo Grisotto pelo constante incentivo.

E em especial, ao companheirismo dos meus queridos colegas da turma de Mestrado de 2003: Adalberto Chagas, Andréa Montebello, Breno Gurgel, Cláudia Bittencourt, Cláudio Figueira, Iara Chao, Ieda Domingues, Leandro Nunes, Moacir Brito, Nelson Bevilacqua, Ricardo Fortis, Rita França (in memorian), Romário Maron e Roseli Spósito. 


\section{RESUMO}

O Pólo Cerâmico de Santa Gertrudes, localizado na região de Rio Claro, no Estado de São Paulo, é o maior do gênero no país, contando com mais de 40 unidades industriais do setor de pisos e revestimentos e responsável por mais da metade da produção nacional.

A área de estudos, denominada Região dos Lagos de Santa Gertrudes, situa-se na bacia hidrográfica do Córrego da Fazenda Itaqui, sub-afluente do Rio Corumbataí, manancial utilizado para o abastecimento público de aproximadamente $650 \mathrm{mil}$ habitantes.

Os lagos não são formações naturais, mas resultantes da inundação de antigas cavas de extração de argila, pelo afloramento do aqüífero da Formação Corumbataí. Nessas cavas, foram depositados resíduos da linha de esmaltação e lançados efluentes líquidos do processo produtivo das cerâmicas, contendo elevadas concentrações de metais, principalmente de boro $(\mathrm{B})$, cádmio $(\mathrm{Cd})$, chumbo $(\mathrm{Pb})$ e zinco $(\mathrm{Zn})$.

Este trabalho de pesquisa buscou oferecer uma alternativa de remediação do solo contaminado, por meio do estudo de três processos de lixiviação de metais, produzida pela lavagem com ácido sulfúrico concentrado e por soluções de peróxido de hidrogênio a $30 \%$ e de ácido clorídrico 0,1 M.

Os resultados obtidos identificaram que a lavagem com ácido sulfúrico concentrado promoveu a redução de $50 \%$ dos teores de $\mathrm{Zn}$ e a lavagem com a solução de ácido clorídrico $0,1 \mathrm{M}$ reduziu os teores de $\mathrm{Pb}$ e $\mathrm{Zn}$ em $15 \%$ e $10 \%$, respectivamente. $\mathrm{O}$ teor remanescente de $\mathrm{Zn}$ no solo tratado com ácido sulfúrico concentrado foi de 117 $\mathrm{mg} / \mathrm{kg}$ e os teores de $\mathrm{Pb}$ e $\mathrm{Zn}$ remanescentes no solo tratado com a solução de ácido clorídrico 0,1 M foram de $806 \mathrm{mgPb} / \mathrm{kg}$ e $213 \mathrm{mgZn} / \mathrm{kg}$, valores estes inferiores aos de intervenção estabelecidos pelo órgão de controle ambiental paulista. 


\begin{abstract}
The Ceramic Pole of Santa Gertrudes, located in the region of Rio Claro, in the State of São Paulo, is the largest of the gender in the country, counting with more than 40 industrial units of the section of floors and coverings and responsible for more of the half of the national production.

The area of studies, denominated Region of the Lakes of Santa Gertrudes, locates at the Córrego da Fazenda Itaqui river basin, sub-affluent of the River Corumbataí, spring used for the public provisioning of approximately 650 thousand inhabitants.

The lakes are not natural formations, but resultants of the flood of old diggings of clay extraction, for the blooming of Formation Corumbatai's aquifer. In these diggings were deposited solid wastes from the line of enamels and thrown liquid effluents of the productive process of the ceramic, containing high concentrations of metals, mainly of boron $(\mathrm{B})$, cadmium $(\mathrm{Cd})$, lead $(\mathrm{Pb})$ e zinc $(\mathrm{Zn})$.

This research work aimed to offer an alternative of remediation of the polluted soil, through the study of three leaching processes of metals, produced by washing of soil with concentrated sulfuric acid and solutions of hydrogen peroxide $30 \%$ and $0,1 \mathrm{M}$ hydrochloric acid.

The obtained results identified that the washing with concentrated sulphuric acid caused a $50 \%$ reduction of $\mathrm{Zn}$ contents and the washing with $0,1 \mathrm{M}$ hydrochloric acid solution reduced $\mathrm{Pb}$ and $\mathrm{Zn}$ contents in $15 \%$ and $10 \%$, respectively. The $\mathrm{Zn}$ contents remaining in the soil processed with concentrated sulphuric acid were $117 \mathrm{mg} / \mathrm{kg}$ and the $\mathrm{Pb}$ and $\mathrm{Zn}$ contents remaining in the soil processed with $0,1 \mathrm{M}$ hydrochloric acid solution were $806 \mathrm{mgPb} / \mathrm{kg}$ and $213 \mathrm{mgZn} / \mathrm{kg}$, values which are lower than the intervention values established by São Paulo’s environmental control agency.
\end{abstract}




\section{SUMÁRIO}

\section{LISTA DE FIGURAS}

\section{LISTA DE TABELAS}

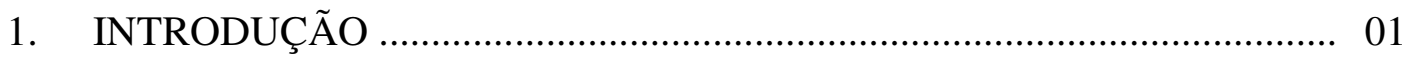

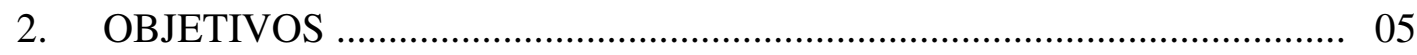

3. REVISÃO BIBLIOGRÁFICA …………………………………….... 06

3.1. Conceito de metal pesado ........................................................................... 06

3.2. Fontes de metais pesados .............................................................................. 06

3.3. Destino dos metais pesados no meio ambiente ………………………….... 07

3.4. Efeitos dos metais pesados no Homem e no meio ambiente ......................... 19

3.5. Tecnologias de remediação de áreas contaminadas com metais pesados ..... 34

4. MATERIAIS E MÉTODOS _..................................................................... 53

4.1. Área de estudo ....................................................................................... 53

4.2. Metodologia para realização da pesquisa ..................................................... 56

5. RESULTADOS E DISCUSSÃO …………………………………….... 62

5.1. Caracterização granulométrica e mineralógica do solo .................................. 62

5.2. Resultados obtidos no ensaio de lixiviação de metais com a utilização do ácido sulfúrico concentrado

5.3. Resultados obtidos no ensaio de lixiviação de metais com a utilização da solução de peróxido de hidrogênio a $30 \%$

5.4. Resultados obtidos no ensaio de lixiviação de metais com a utilização da solução de ácido clorídrico $0,1 \mathrm{M}$

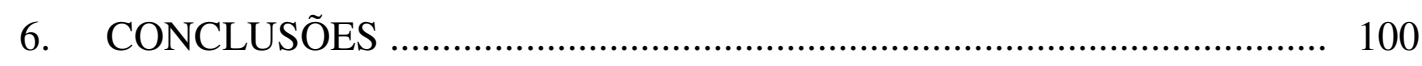

7. RECOMENDAÇÕES PARA FUTURAS PESQUISAS ........................... 102

REFERÊNCIAS BIBLIOGRÁFICAS _................................................... 103 


\section{LISTA DE FIGURAS}

3.5.1 Acidithiobacillus ferrooxidans

3.5.2 Ciclo microbiano do enxofre para remoção de metais pesados em solos e sedimentos

3.5.3 Processo de lixiviação ex situ.

3.5.4 Fluxograma do processo de tratamento de extração/classificação do solo contaminado escavado (ex situ)

3.5.5 (a) Hidrociclone. (b) Leito fluidizado ................................................. 48

3.5.6 Remediação eletrocinética ............................................................. 50

3.5.7 Extração de vapores do solo ................................................................ 51

3.5.8 Fluxograma do processo de tratamento térmico de solos contaminados.. 52

4.1.1 Localização das áreas I, II e III ........................................................... 55

4.2.1 Equipamento para ensaios de biolixiviação ........................................... 59

5.2.1 Consumo de ácido sulfúrico concentrado por quilo de solo seco ........... 68

5.2.2 Teores mínimos, médios e máximos de $\mathrm{Pb}$ detectados na fase sólida da suspensão - Ensaio de lixiviação de metais com ácido sulfúrico concentrado

5.2.3 Diagrama Eh/pH para o sistema $\mathrm{Pb}-\mathrm{S}-\mathrm{C}-\mathrm{O}-\mathrm{H}\left(25^{\circ} \mathrm{C}, 1\right.$ bar $)$

5.2.4 Teores mínimos, médios e máximos de Zn detectados na fase sólida da suspensão - Ensaio de lixiviação de metais com ácido sulfúrico concentrado

5.2.5 Diagrama Eh/pH para o sistema $\mathrm{Zn}-\mathrm{O}-\mathrm{H}-\mathrm{S}-\mathrm{C}\left(25^{\circ} \mathrm{C}, 1 \mathrm{bar}\right)$

5.2.6 Concentrações mínimas, médias e máximas de $\mathrm{Pb}$ detectadas na fase líquida da suspensão - Ensaio de lixiviação de metais com ácido sulfúrico concentrado

5.2.7 Concentrações mínimas, médias e máximas de Zn detectadas na fase líquida da suspensão - Ensaio de lixiviação de metais com ácido sulfúrico concentrado 
5.3.1 Teores mínimos, médios e máximos de $\mathrm{Pb}$ detectados no solo bruto e na fase sólida da suspensão - Ensaio de lixiviação de metais com solução de peróxido de hidrogênio a $30 \%$

5.3.2 Teores médios de carbono, hidrogênio e nitrogênio do solo bruto e na fase sólida da suspensão - Ensaios de lixiviação de metais com solução de peróxido de hidrogênio a $30 \%$

5.3.3 Teores mínimos, médios e máximos de Zn detectados no solo bruto e na fase sólida da suspensão - Ensaio de lixiviação de metais com solução de peróxido de hidrogênio a $30 \%$

5.3.4 Concentrações mínimas, médias e máximas de $\mathrm{Pb}$ detectadas na fase líquida da suspensão - Ensaio de lixiviação de metais com solução de peróxido de hidrogênio a $30 \%$

5.3.5 Concentrações mínimas, médias e máximas de Zn detectadas na fase líquida da suspensão - Ensaio de lixiviação de metais com solução de peróxido de hidrogênio a $30 \%$

5.4.1 Concentrações mínimas, médias e máximas de $\mathrm{Pb}$ detectadas no lixiviado - Ensaio de lixiviação de metais com solução de ácido clorídrico $0,1 \mathrm{M}$

5.4.2 Concentrações mínimas, médias e máximas de Zn detectadas no lixiviado - Ensaio de lixiviação de metais com solução de ácido clorídrico $0,1 \mathrm{M}$ 


\section{LISTA DE TABELAS}

3.1.1 Origem e destino no meio ambiente dos principais elementos classificados como metais pesados

3.4.1 Efeitos tóxicos ao Homem produzidos pelos metais pesados

4.1.1. Síntese das análises de $\mathrm{Pb}, \mathrm{B}, \mathrm{Zn}, \mathrm{Cd}$ e $\mathrm{pH}$ efetuadas em amostras de solo, sedimentos e águas (superficiais e subterrâneas) coletadas na Região dos Lagos de Santa Gertrudes

4.2.1 Teores de carbono do solo bruto e dosagens de $\mathrm{H}_{2} \mathrm{O}_{2} 30 \%$

5.1.1 Distribuição granulométrica da amostra do solo bruto

5.1.2 Fases cristalinas da amostra de solo contaminado da Região dos Lagos de Santa Gertrudes

5.1.3 Fluorescência de raios-X

5.2.1 Amostras da fase sólida da suspensão - Ensaio de lixiviação de metais com ácido sulfúrico concentrado

5.2.2 Massa de $\mathrm{Pb}$ na fase sólida das suspensões sem acidificação e tratadas com ácido sulfúrico concentrado

5.2.3 Massa de Zn na fase sólida das suspensões sem acidificação e tratadas com ácido sulfúrico concentrado

5.2.4 Amostras da fase líquida da suspensão - Ensaio de lixiviação de metais com ácido sulfúrico concentrado

5.2.5 Massa de $\mathrm{Pb}$ nas suspensões sem acidificação e tratadas com ácido sulfúrico concentrado

5.2.6 Massa de Zn nas suspensões sem acidificação e tratadas com ácido sulfúrico concentrado

5.3.1 Amostras da fase sólida da suspensão - Ensaio de lixiviação de metais com solução de peróxido de hidrogênio a $30 \%$

5.3.2 Massa de $\mathrm{Pb}$ na fase sólida das suspensões não oxidada e tratadas com solução de peróxido de hidrogênio a $30 \%$

5.3.3 Massa de $\mathrm{Zn}$ na fase sólida das suspensões não oxidada e tratadas com solução de peróxido de hidrogênio a $30 \%$ 
5.3.4 Amostras da fase líquida da suspensão - Ensaio de lixiviação de metais com solução de peróxido de hidrogênio a $30 \%$

5.3.5 Massa de $\mathrm{Pb}$ nas suspensões não oxidada e tratadas com solução de peróxido de hidrogênio a $30 \%$

5.3.6 Massa de Zn nas suspensões não oxidada e tratadas com solução de peróxido de hidrogênio a $30 \%$

5.4.1 Concentrações de $\mathrm{Pb}$ e $\mathrm{Zn}$ das amostras do lixiviado - Ensaio de lixiviação de metais com solução de ácido clorídrico 0,1 M

5.4.2 Massa de $\mathrm{Pb}$ nas suspensões não acidificada e tratadas com solução de ácido clorídrico $0,1 \mathrm{M}$

5.4.3 Massa de $\mathrm{Zn}$ nas suspensões não acidificada e tratadas com solução de ácido clorídrico $0,1 \mathrm{M}$ 


\section{INTRODUÇÃO}

Conforme projeto de avaliação mundial da degradação do solo (GLSOD - Global Assessment of Soil Degradation), pertencente ao Programa de Meio Ambiente das Nações Unidas, implementado e executado pelo Centro Internacional de Informação e Referência de Solos (ISRIC), os fatores de degradação do solo são (DIAS e GRIFFITH, 1998):

- desmatamento ou remoção da cobertura vegetal natural para fins agrícolas, reflorestamento, construção de estradas e urbanização;

- atividades pastoris;

- atividades agrícolas, incluindo ampla variedade de práticas agrícolas, como uso excessivo de fertilizantes, uso de água de irrigação de baixa qualidade, uso inapropriado de máquinas agrícolas e ausência de práticas conservacionistas de solo;

- exploração intensa dos recursos florestais para obtenção de energia e

- $\quad$ atividades industriais que causam a poluição do solo.

Ainda de acordo com o projeto, cerca de $15 \%$ do solo mundial encontra-se de alguma forma degradado.

Entre os fatores de degradação, a pecuária é responsável por 34,5\% das áreas mundiais degradadas, seguida pelo desmatamento (29,4\%), atividades agrícolas $(28,1 \%)$, exploração intensa da vegetação para fins domésticos $(6,8 \%)$ e atividades industriais $(1,2 \%)$.

No Brasil, a identificação da extensão de solos degradados é precária, porém as estimativas indicam o desmatamento e as atividades agrícolas como os principais fatores.

A degradação dos solos não pode ser avaliada somente pela sua extensão, mas também pela sua intensidade. $\mathrm{O}$ impacto causado por minerações pode resultar em uma área de influência muito maior do que a área de lavra, proporcionando, além da degradação do solo, a contaminação dos recursos hídricos, por possibilitar o lançamento de metais pesados nos corpos d'água. Da mesma forma, a necessidade da construção de barragens para bacias de depósito de rejeitos do processo de beneficiamento de minérios resulta na ampliação do impacto do empreendimento e conseqüentemente do seu passivo ambiental. 
Em estudo realizado pela European Environment Agency (EEA, 1999), foi estimada a existência de aproximadamente 1.500 .000 áreas potencialmente contaminadas e 300.000 áreas contaminadas por poluentes orgânicos e inorgânicos nos doze países membros da Comunidade Européia.

Segundo CETESB-GTZ (2001), áreas potencialmente contaminadas são aquelas onde estão sendo ou foram desenvolvidas atividades potencialmente contaminadoras, ou seja, onde ocorre ou ocorreu o manejo de substâncias cujas características físicoquímicas, biológicas e toxicológicas podem causar danos e/ou riscos aos bens a proteger (área de proteção de mananciais, reservas de águas subterrâneas, poços de abastecimento de água, área urbanizada, região agrícola, distrito industrial, etc.); áreas contaminadas são aquelas onde há comprovadamente contaminação, confirmada por análises, que podem determinar danos e/ou riscos aos bens a proteger, localizados nas próprias áreas ou em seus arredores.

Entre os países pesquisados pela EEA em 1999, a França apresentou o maior número de áreas potencialmente contaminadas, aproximadamente 800.000, seguida pela Alemanha, com 240.000, Holanda, com 120.000 e Inglaterra, com 100.000, sendo o custo estimado para a remediação das áreas identificadas nos doze países da Comunidade Européia de US\$ 110 milhões (EEA, 1999).

Os metais pesados figuram entre os principais contaminantes identificados e tornamse um problema crescente em vários países da Europa, Estados Unidos, Japão e naqueles em desenvolvimento.

Nos Estados Unidos, o chumbo foi encontrado em $15 \%$ das 1.200 áreas relacionadas na National Priorities List (NPL) pela EPA (Environmental Protection Agency), seguido pelo cromo (11\%), cádmio (8\%) e cobre (7\%) (MULLIGAN, YONG e GIBBS, 1999).

Na Grã-Bretanha, estima-se que aproximadamente 180.000 hectares de solo estejam contaminados com metais tóxicos (LLOYD, 2002).

As atividades antrópicas podem alterar significativamente os ciclos geoquímicos naturais dos metais pesados. A acumulação desses elementos na litosfera é preocupante, pois ao contrário dos compostos xenobióticos orgânicos, não estão sujeitos a qualquer degradação (BOURG, 1995). 
Os metais pesados presentes em áreas contaminadas ocorrem conforme o tipo de atividade desenvolvida no local. Os teores dos contaminantes e as formas químicas e físicas dependem das atividades e formas de disposição dos resíduos sólidos na área. Outros fatores que influenciam na forma, concentração e distribuição dos contaminantes incluem as características químicas e os mecanismos de transporte no solo e nas águas subterrâneas (GWRTAC, 1997).

A forma química do metal influi em sua solubilidade, mobilidade e toxicidade e depende da fonte do resíduo sólido e das características químicas do solo e da água subterrânea da área contaminada.

As tecnologias disponíveis para remediação de áreas contaminadas por metais pesados podem ser agrupadas em biológicas, físico-químicas e térmicas e são aplicáveis na própria área (in situ) ou ex situ, pelo tratamento do solo escavado, sendo estas baseadas na bioacumulação, lixiviação ou dessorção, volatilização, isolamento físico e na imobilização física e química.

A remediação dos solos contaminados por metais pesados através das tecnologias $e x$ situ apresenta elevado custo, entre US\$ 8 e US\$ 12 por habitante nos países industrializados, devido à firme adesão desses compostos às partículas do solo (WASAY, BARRINGTON e TOKUNAGA, 1998).

Geralmente, as tecnologias in situ são mais econômicas e seguras, pois, a escavação do solo não é necessária (Di PALMA et al., 2003).

Baseada na necessidade do desenvolvimento de novas tecnologias de remediação de solos contaminados por metais pesados economicamente mais acessíveis, foi iniciada em 2003, a pesquisa de Doutorado do aluno André Negrão de Moura do Departamento de Engenharia Hidráulica e Sanitária da Escola Politécnica da Universidade de São Paulo, sendo escolhida como área de estudo a Região dos Lagos de Santa Gertrudes, localizada no Estado de São Paulo, devido ao histórico de deposição de resíduos e de lançamento de efluentes líquidos dos processos cerâmicos de indústrias dessa região, contendo elevadas concentrações de $\mathrm{B}, \mathrm{Cd}, \mathrm{Pb}$ e $\mathrm{Zn}$. Esse descarte indevido proporcionou a contaminação do solo e do lençol freático da bacia do Córrego da Fazenda Itaqui, sub-afluente do Rio Corumbataí, manancial responsável pelo abastecimento de sete municípios do interior paulista e de mais de 650 mil habitantes. 
A partir das amostras coletadas nesta área, foi desenvolvida a pesquisa de lixiviação dos metais por meio da atividade bacteriana das espécies Acidithiobacillus ferrooxidans e A. thiooxidans, microrganismos reconhecidamente responsáveis pelo processo da biohidrometalurgia, largamente utilizado nas indústrias minerárias.

Alternativamente, essa pesquisa de mestrado buscou a extração desses metais através da utilização de agentes químicos - ácidos clorídrico e sulfúrico e peróxido de hidrogênio - substâncias rotineiramente utilizadas em processos de lixiviação de metais de solos. 


\section{OBJETIVOS}

Estudo da eficácia da remoção dos metais $\mathrm{Pb}$ e $\mathrm{Zn}$ do solo coletado na Região dos Lagos de Santa Gertrudes, localizada no Estado de São Paulo, por meio da lavagem do solo com os agentes oxidantes: ácido sulfúrico concentrado, peróxido de hidrogênio a 30\% e solução de ácido clorídrico 0,1 M.

Os resultados obtidos foram relacionados às características geoquímicas do solo e dos elementos determinados e após comparação entre os três processos, sugeriu-se uma alternativa de remediação da área contaminada pelo depósito de resíduos do processo cerâmico das indústrias da região. 


\section{REVISÃO BIBLIOGRÁFICA}

\subsection{Conceito de metal pesado}

Metal pesado ou metal-traço é o termo utilizado para um enorme grupo de elementos traço, biológica e industrialmente importantes e presentes em teores inferiores a $1 \%$ (freqüentemente abaixo de $0,01 \%$ ou $100 \mathrm{mg} / \mathrm{kg}$ ) em rochas da crosta terrestre (ALLOWAY, 1995).

Do ponto de vista químico, metal pesado é o termo mais amplamente reconhecido e utilizado para um grande número de elementos com massa específica maior do que $5,5 \mathrm{~g} / \mathrm{cm}^{3}$. Outros nomes têm sido utilizados para esse grupo de elementos, sendo metais tóxicos o menos apropriado, pois, todos os elementos traço são tóxicos para os organismos vivos quando presentes no meio em teores elevados. Porém, alguns metais como o cobalto, cobre, cromo, manganês, molibdênio e zinco são essenciais em baixas concentrações para o saudável crescimento de animais e plantas.

O termo metal pesado ainda é geralmente utilizado pejorativamente para ênfase dos aspectos poluidores e tóxicos.

Um novo termo crescentemente utilizado é o de elemento potencialmente tóxico e refere-se à toxicologia passível de ser provocada pelos metais conforme vias, doses e períodos de exposição dos organismos vegetais e animais (ALLOWAY, 1995; SILVA et al., 2001).

Nas atividades agrícolas, os metais, principalmente cobre, manganês e zinco, são denominados micronutrientes e caracterizados como essenciais ao desenvolvimento de culturas.

\subsection{Fontes de metais pesados}

Os principais elementos químicos enquadrados no conceito de metal pesado são: $\mathrm{Ag}$ (prata), $\mathrm{Cd}$ (cádmio), $\mathrm{Cr}$ (cromo), $\mathrm{Cu}$ (cobre), $\mathrm{Hg}$ (mercúrio), $\mathrm{Ni}$ (níquel), $\mathrm{Pb}$ (chumbo) e Zn (zinco). Estes elementos são encontrados naturalmente no solo em teores variáveis, porém inferiores aqueles considerados tóxicos para diferentes organismos vivos. Dentre eles, $\mathrm{Cr}, \mathrm{Cu}$ e $\mathrm{Zn}$ são essenciais aos organismos em certas quantidades, enquanto outros não desempenham qualquer função no metabolismo, sendo tóxicos às plantas e animais (SILVA et al., 2001). 
As fontes de contaminação de solos por metais pesados incluem as atividades minerárias, fundição, produção e reciclagem de baterias, produtos químicos utilizados na agricultura e na indústria, processos de incineração e emissões veiculares.

Os metais pesados são tóxicos aos homens e animais e podem contaminar as águas subterrâneas se não forem dispostos adequadamente. No solo, os metais pesados são fortemente retidos, e o impacto ao meio ambiente e à saúde humana persiste por longos períodos de tempo (ANDREW HONG et al., 1999).

Os despejos líquidos industriais são as principais fontes de contaminação das águas superficiais com metais pesados, pois esses elementos são utilizados nas linhas de produção e quando não tratados adequadamente acabam sendo lançados nos cursos d'água (SILVA et al., 2001).

\subsection{Destino dos metais pesados no meio ambiente}

A mobilidade dos metais pesados no meio ambiente depende de interações entre substâncias químicas aquosas e heterogêneas, bem como, de fenômenos de coagulação e floculação de partículas. A hidrólise e a concentração de substâncias complexadas dissolvidas tendem a aumentar a solubilidade enquanto a precipitação e a adsorção prejudicam o transporte e disponibilidade dos metais pesados. A distribuição desses elementos entre as várias espécies é o resultado de uma série de reações químicas heterogêneas e de dissolução (BOURG, 1995).

A especiação dos metais pesados em solos e nas águas subterrâneas é determinada pela reatividade biogeoquímica dos elementos, a qual é controlada pelas características químicas da água, microflora e propriedades de porosidade dos sólidos.

Os mais importantes efeitos da atividade microbiana no comportamento dos metais pesados no solo provêm da degradação da matéria orgânica e das reações de óxido redução envolvendo oxihidróxidos de $\mathrm{Fe}$ e $\mathrm{Mn}$ e de sulfetos. Em ambientes com valores de $\mathrm{pH}$ maiores ou iguais a 7 e em condições oxidantes, o Fe e Mn amorfos ou como óxidos cristalinos são fortes adsorventes ou matrizes de co-precipitação dos metais pesados. Sob condições redutoras, os metais pesados são removidos de uma solução como sulfetos minerais. 
Quando o ambiente é ligeiramente redutor e em valores de $\mathrm{pH}$ iguais ou inferiores a 7, os oxihidróxidos de $\mathrm{Fe}$ e Mn são solubilizados pela redução das formas $\mathrm{Fe}^{3+} \mathrm{e}$ $\mathrm{Mn}^{4+}$. Sob essas condições, quando o meio é ligeiramente alcalino, o Fe e Mn podem ser precipitados como carbonatos, porém esses minerais certamente são menos adsorventes do que os correspondentes óxidos e hidróxidos.

Os ambientes que possuem baixo $\mathrm{pH}$ e valores entre moderado a elevado potencial redox são os mais favoráveis à ocorrência da solubilização dos metais pesados.

A solubilidade e conseqüente mobilidade dos metais pesados no meio ambiente pode ser acrescida por três principais processos que produzem a alteração na especiação dos elementos (BOURG, 1995):

- queda do $\mathrm{pH}$, que pode dissolver e/ou dessorver os metais pesados da fase sólida;

- alteração das condições óxido-redutoras, que induzem o moderado a alto potencial redox;

- aumento da concentração de sais inorgânicos (para promover a competição pelos sais catiônicos em reações heterogêneas e produzir complexos dissolvidos de sais aniônicos) e dos agentes complexantes naturais ou sintéticos.

A seguir, é apresentada uma síntese da origem e principais destinos dos elementos químicos caracterizados como metais pesados.

\subsubsection{Ag (Prata)}

A prata é um elemento raro que ocorre naturalmente em minérios, primariamente como sulfetos, em associação com o ferro (pirita), chumbo (galena) e ouro. É geralmente encontrada em teores de $0,1 \mathrm{ppm}$ na crosta terrestre e $0,3 \mathrm{ppm}$ nos solos. Apresenta-se em quatro estados de oxidação $(0,1+, 2+$ e $3+)$, sendo as valências 0 e 1+ mais freqüientes do que as formas bivalentes e trivalentes (US DEPARTMENT OF HEALTH AND HUMAN SERVICES, 1990).

Nas águas superficiais, é encontrada em várias formas: como íon monovalente (sulfeto, bicarbonato ou sais de sulfato), em íons mais complexos formados por cloretos e sulfatos e adsorvida à matéria particulada.

A prata é liberada para o ar e a água através de processos naturais como o intemperismo de rochas e a erosão dos solos. As atividades antropogênicas responsáveis pelas principais fontes de liberação de prata no ar atmosférico incluem 
a mineração, metalurgia, queima de combustíveis fósseis e incineração de resíduos sólidos urbanos.

A maior fonte de liberação de prata nas águas superficiais é o lançamento de efluentes de processos fotográficos, têxteis e de refino de petróleo.

No solo, a ocorrência da prata é devida à disposição de lodo de processos de tratamento de águas residuárias e de resíduos sólidos urbanos.

A prata pode ser lixiviada às águas subterrâneas sob condições ácidas e redutoras do solo.

\subsubsection{Cd (Cádmio)}

O cádmio ocorre naturalmente na forma $\mathrm{CdS}$ e $\mathrm{CdCO}_{3}$ e é recuperado como subproduto da extração mineral do chumbo, zinco e cobre. As fontes de contaminação pelo cádmio incluem os processos de galvanização e a disposição de resíduos sólidos (GWRTAC, 1997). O carvão e outros combustíveis fósseis contêm cádmio e a combustão dos mesmos distribui o elemento no meio ambiente (SILVA et al., 2001). O cádmio é um metal de grande interesse toxicológico na época atual. A elevada resistência à corrosão e determinadas propriedades eletroquímicas desse metal são responsáveis pelas largas aplicações em galvanização e revestimento elétrico, na fabricação de plásticos (SILVA et al., 2001), de tintas (amarelo-cádmio e vermelhocádmio) $^{1}$ e nas pilhas de níquel e cádmio (A Resolução 257 do CONAMA de 30/06/1999, artigos $5^{\circ}$ e $6^{\circ}$, estabelece os teores máximos permitidos de mercúrio, cádmio e chumbo na fabricação, importação e comercialização de pilhas e baterias). As formas mais comuns do cádmio incluem o $\mathrm{Cd}^{2+}$, complexos de cianeto de cádmio e $\mathrm{Cd}(\mathrm{OH})_{2}$. A presença das formas insolúveis do hidróxido $-\mathrm{Cd}(\mathrm{OH})_{2}-$ e do carbonato $-\mathrm{CdCO}_{3}$ - é dominante em valores elevados de $\mathrm{pH}$, no entanto, o $\mathrm{Cd}^{2+} \mathrm{e}$ as espécies solúveis de sulfato são as formas dominantes do cádmio em pH inferior a 8. Sob condições redutoras, na presença do enxofre, a forma insolúvel do CdS é produzida. O cádmio pode ser precipitado na presença de fosfato, arsenato, cromato e outros ânions, porém, a solubilidade variará com o $\mathrm{pH}$ e outros fatores químicos (GWRTAC, 1997).

\footnotetext{
${ }^{1}$ http://ciarte.no.sapo.pt/material/pigmento/pig_elem.htm
} 
O cádmio tem mais mobilidade em ambientes aquáticos do que a maioria dos outros metais. É também bioacumulativo e persistente no meio ambiente - meia vida entre 10 e 30 anos. É encontrado nas águas superficiais e subterrâneas como o íon bivalente hidratado, ou como um complexo iônico com outras substâncias inorgânicas ou orgânicas. Enquanto as formas solúveis podem migrar para as águas, o cádmio, em complexos insolúveis ou adsorvido a sedimentos, é relativamente imóvel. De forma semelhante, o cádmio pode existir na forma solúvel, ou em complexos insolúveis com componentes inorgânicos e orgânicos do solo (LABUNSKA, STRINGER e BRIDGEN, 2000).

O cádmio é removido das águas naturais pela precipitação e adsorção à superfície dos minerais, especialmente óxidos minerais, em pH superior a 6. A remoção por esses mecanismos aumenta com o aumento do $\mathrm{pH}$. A adsorção é também influenciada pela capacidade de troca cationica das argilas, carbonato de minerais e matéria orgânica presente em solos e sedimentos. Sob condições redutoras, a precipitação como CdS controla a mobilidade do cádmio (GWRTAC, 1997).

\subsubsection{Cr (Cromo)}

O cromo é utilizado na indústria metalúrgica e química como agente oxidante e na produção de compostos utilizados em pinturas, explosivos, tinturas, cerâmicas e papéis. Está presente também em alguns fertilizantes e pesticidas, em sistemas de extinção de incêndio e em serpentinas de sistemas de aquecimento e refrigeração (SILVA et al., 2001).

O cromo é um dos elementos menos comuns no meio ambiente e não ocorre naturalmente na forma elementar, mas somente em compostos (GWRTAC, 1997). Apresenta-se em estados de valência que variam de 2- a 6+, no entanto, as formas trivalente $\left(\mathrm{Cr}^{3+}\right)$ e hexavalente $\left(\mathrm{Cr}^{6+}\right)$ são as mais estáveis que existem na superfície e sub-superfície dos ambientes.

$\mathrm{O}$ cromo trivalente existe como cátion $\left(\mathrm{Cr}^{3+}\right)$ e como hidróxidos complexos como o $\mathrm{CrOH}^{2+}, \mathrm{Cr}(\mathrm{OH})_{3}{ }^{0}$ e $\mathrm{Cr}(\mathrm{OH})_{4}{ }^{-}$, sendo que de todas as formas, o $\mathrm{Cr}^{3+}$ e o $\mathrm{CrOH}^{2+}$ são as predominantes em uma ampla faixa de $\mathrm{pH}$. As formas catiônicas do cromo trivalente são menos móveis, devido à sua limitada solubilidade em água e adsorção na superfície da argila (CHINTHAMREDDY e REDDY, 1999) e aos óxidos minerais em pH abaixo de 5, devido à formação do $\mathrm{Cr}(\mathrm{OH})_{3(\mathrm{~s})}$ (GWRTAC, 1997). 
O cromo hexavalente está mais comumente presente como oxiácidos ou ânions como o cromato ácido $\left(\mathrm{HCrO}_{4}^{-}\right)$, dicromato $\left(\mathrm{Cr}_{2} \mathrm{O}_{7}{ }^{2-}\right)$, e $\mathrm{o}$ cromato $\left(\mathrm{CrO}_{4}^{2-}\right)$ (CHINTHAMREDDY e REDDY, 1999). $\mathrm{O} \mathrm{Cr}^{6+}$ é a forma dominante em aqüíferos superficiais sob condições aeróbias e pode ser reduzido a cromo trivalente pela matéria orgânica do solo e pelos íons $\mathrm{S}^{2-}$ e $\mathrm{Fe}^{2+}$ em condições anaeróbias, geralmente encontradas em águas subterrâneas (GWRTAC, 1997).

A maioria dos sólidos presentes nos solos apresenta carga elétrica negativa que inibe a adsorção do $\mathrm{Cr}^{6+}$. As argilas possuem grande capacidade de adsorção dos metais catiônicos, porém esse material pouco interage com o $\mathrm{Cr}^{6+}$ devido à similaridade das cargas elétricas presentes na superfície das partículas de argila e nas formas aniônicas do cromo hexavalente. O único sólido presente nos solos que adsorve o $\mathrm{Cr}^{6+}$ é o oxidohidróxido de ferro. A quantidade de $\mathrm{Cr}^{6+}$ adsorvido aos sólidos de ferro aumenta com o decréscimo do pH (GWRTAC, 1997).

\subsubsection{Cu (Cobre)}

O cobre pode existir em águas naturais na forma dissolvida do íon cúprico $\left(\mathrm{Cu}^{2+}\right)$ ou complexada com ânions inorgânicos (carbonatos e cloretos) ou ligantes orgânicos (ácidos húmicos e fúlvicos). Pode também estar presente como precipitado insolúvel (hidróxidos, fosfatos ou sulfetos) ou adsorvido ao material particulado e aos sedimentos em corpos d'água. As concentrações de cada uma dessas formas são dependentes de uma série de parâmetros químicos, incluindo $\mathrm{pH}$, salinidade, alcalinidade e a presença de ligantes orgânicos, ânions inorgânicos e outros íons metálicos. No entanto, estudos têm mostrado, freqüentemente, que a concentração do íon cúprico é baixa, comparada aos teores de cobre associados ao material em suspensão e sedimentos (LABUNSKA, STRINGER e BRIDGEN, 2000).

Em solos, o cobre tem uma alta afinidade para a sorção (adsorção e absorção) por ligantes orgânicos e inorgânicos (ácidos húmicos e fúlvicos, hidróxidos de ferro, alumínio e manganês). No entanto, o cobre pode também existir como íons e complexos solúveis. A forma solúvel do cobre é muito mais móvel do que as formas ligadas à matéria orgânica ou presente como precipitado insolúvel. Dessa forma, o sulfato ou o cloreto de cobre, presente na cinza de incineradores de resíduos sólidos urbanos ou em resíduos de minas, é muito mais biodisponível e migratório do que o 
cobre orgânico encontrado em lodos de esgoto (LABUNSKA, STRINGER e BRIDGEN, 2000).

\subsubsection{Hg (Mercúrio)}

A liberação de mercúrio pela queima de carvão mineral é a maior fonte de contaminação do meio ambiente por esse metal pesado (GWRTAC, 1997).

$\mathrm{O}$ mercúrio possui as formas líquida e de vapor em temperatura ambiente e, assim sendo, o seu comportamento ambiental difere da maioria dos elementos tóxicos (LABUNSKA, STRINGER e BRIDGEN, 2000).

O mercúrio pode existir em três estados de valência: $0,1+$ e 2+. Após o lançamento no meio ambiente, o mercúrio geralmente ocorre nas formas $\mathrm{Hg}^{0}, \mathrm{Hg}^{2+}, \mathrm{Hg}_{2}^{2+}$, ou nas formas de metil e etil mercúrio. O potencial redox e o $\mathrm{pH}$ do meio determinam as

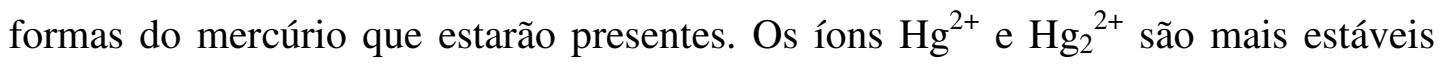
sob condições oxidantes. Na ocorrência de ligeiras condições de redução, as formas do mercúrio orgânico e inorgânico podem ser reduzidas a mercúrio elementar, no qual pode ser convertido a metil e etil mercúrio por processos bióticos e abióticos. $\mathrm{O}$ mercúrio é mais tóxico em suas formas metiladas, pois são solúveis em água e voláteis no ar (GWRTAC, 1997).

No ar atmosférico, o mercúrio elementar $\left(\mathrm{Hg}^{0}\right)$ é a forma mais comum e, como vapor, é responsável pela propagação global do mercúrio. Além disso, em um grau muito menor, o mercúrio pode estar associado ao material particulado, que é removido por deposição seca ou úmida (LABUNSKA, STRINGER e BRIDGEN, 2000).

A biotransformação é o processo mais influente no destino do mercúrio nas águas superficiais. Sob certas condições, qualquer forma química do mercúrio lançada em corpos d'água pode ser microbiologicamente convertida em íons de metilmercúrio (US DEPARTMENT OF HEALTH AND HUMAN SERVICES, 1999). A anaerobiose favorece a atividade das bactérias sulfo-redutoras, maiores responsáveis pela metilação de mercúrio no meio ambiente, como também, o mercúrio elementar volátil pode ser formado a partir da desmetilação do metilmercúrio ou da redução do mercúrio inorgânico. O baixo $\mathrm{pH}$ favorece o crescimento de fungos como as espécies Cândida albicans e Saccharomyces cerevisiae, que podem metilar o mercúrio, como 
também, reduzir o mercúrio iônico em mercúrio elementar (US DEPARTMENT OF HEALTH AND HUMAN SERVICES, 1999).

O aumento da concentração de carbono orgânico dissolvido reduz a metilação do mercúrio na coluna d'água, possivelmente como resultado da adesão dos íons livres de mercúrio ao carbono orgânico dissolvido em baixo pH ou à inibição da atividade das bactérias sulfo-redutoras. Em pH entre 4 e 9 e em concentrações usuais de sulfetos no ambiente aquático, o mercúrio será transformado em sulfeto de mercúrio. Este composto é relativamente insolúvel em água $\left(4 \times 10^{-53} \mathrm{mg} / \mathrm{L}\right)$, e dessa forma será precipitado, reduzindo a disponibilidade de mercúrio para os peixes. Sob condições ácidas, no entanto, a atividade do íon sulfeto é reduzida e consequentemente ocorre a inibição da ocorrência do sulfeto de mercúrio e o favorecimento da formação do metilmercúrio. $\mathrm{O}$ baixo $\mathrm{pH}$ e elevados teores de mercúrio em sedimentos favorecem a formação do metilmercúrio, que apresenta grande potencial de biodisponibilidade para organismos aquáticos em relação aos compostos inorgânicos de mercúrio (US DEPARTMENT OF HEALTH AND HUMAN SERVICES, 1999).

As águas superficiais podem ser saturadas com o mercúrio elementar volátil, no entanto, os sedimentos são a primeira fonte de mercúrio das águas superficiais. Durante os meses de verão, a concentração do mercúrio elementar e do metilmercúrio na superfície dos corpos d'água diminui pela evaporação, porém, ela permanece constante em águas profundas. A redução abiótica do mercúrio inorgânico para o orgânico em sistemas aquáticos também pode ocorrer, particularmente na presença de substâncias húmicas solúveis. Este processo de redução é otimizado pela luz solar e ocorre sob condições aeróbias e anaeróbias e é inibido pela competição com os íons de cloro (US DEPARTMENT OF HEALTH AND HUMAN SERVICES, 1999).

Os compostos de mercúrio presentes no solo estão submetidos às mesmas transformações químicas e biológicas descritas para as águas superficiais. $\mathrm{O}$ mercúrio mercúrico $\left(\mathrm{Hg}^{2+}\right)$ geralmente forma vários complexos com o cloro $\mathrm{e}$ hidróxidos no solo. A formação e a degradação do mercúrio orgânico no solo aparentemente são mediadas pelos mesmos processos microbiológicos e abióticos ocorridos nas águas superficiais. A grande presença de íons de cloro reduz a metilação do mercúrio em sedimentos de rios, lodos e no solo, ao passo que elevados 
teores de carbono orgânico e de íons de sulfato aumentam a metilação nos sedimentos. Em águas correntes e ecossistemas estuarinos, a presença de íons de cloro $(0,02 \mathrm{M})$ pode acelerar a liberação de mercúrio dos sedimentos. Aparentemente, a reação biológica predominante nos solos é a redução do $\mathrm{Hg}^{2+}$ a sulfeto de mercúrio através da ação das bactérias sulfo-redutoras sob condições anaeróbias. Devido à baixa solubilidade em água, o sulfeto de mercúrio possui limitada mobilidade no solo. Microrganismos aeróbios podem solubilizar o $\mathrm{Hg}^{2+}$ a partir da oxidação do sulfeto de mercúrio à sulfato, com $\mathrm{o}^{2+}$ sendo reduzido a mercúrio elementar (US DEPARTMENT OF HEALTH AND HUMAN SERVICES, 1999).

\subsubsection{Ni (Níquel)}

O níquel ocorre naturalmente na crosta terrestre, combinado primariamente com o oxigênio ou enxofre como óxidos e sulfetos e em cinco estados de oxidação (1-, 0, $2+, 3+$ e $4+$ ), sendo a forma bivalente altamente solúvel no meio ambiente (US DEPARTMENT OF HEALTH AND HUMAN SERVICES, 2003).

Esse metal é liberado para o ar atmosférico durante as atividades de mineração, por processos industriais que utilizam compostos de níquel, pela queima de óleo e carvão em usinas de geração de energia elétrica e na incineração de resíduos sólidos urbanos.

A ocorrência de níquel nas águas superficiais deve-se ao transporte do elemento presente no solo pelo escoamento das águas pluviais e pelo lançamento de esgotos domésticos e águas residuárias industriais (US DEPARTMENT OF HEALTH AND HUMAN SERVICES, 2003).

\subsubsection{Pb (Chumbo)}

O chumbo é um metal praticamente onipresente, graças à ocorrência natural no meio ambiente e ao seu uso industrial (SILVA et al., 2001).

A contaminação dos solos por chumbo pode ocorrer pelas atividades minerárias, disposição de lodo proveniente de estações de tratamento de água e de esgotos, reciclagem de baterias, deposição de cinzas de incineradores de resíduos sólidos e de pigmentos utilizados em tintas (MERCIER, DUCHESNE e CARLES-GIBERGUES, 2002). 
Dois estados de oxidação do chumbo, o 2+ e o 4+, são estáveis, mas a química ambiental é dominada pelo íon $\mathrm{Pb}^{2+}$, seus compostos e complexos. Em geral, o íon bivalente é mais tóxico do que os complexos inorgânicos (LABUNSKA, STRINGER e BRIDGEN, 2000).

O chumbo tende a formar compostos com ânions que apresentam baixa solubilidade, como os hidróxidos, carbonatos e fosfatos. Portanto, a quantidade de chumbo que permanece em suspensão nas águas superficiais, dependendo do $\mathrm{pH}$ e da salinidade, é freqüentemente baixa. Uma fração significativa de chumbo insolúvel pode ser incorporada ao material particulado presente em escoamentos de águas pluviais (LABUNSKA, STRINGER e BRIDGEN, 2000).

Em solos e sedimentos, o destino do chumbo é afetado por processos similares, que freqüentemente levam à formação de complexos organometálicos relativamente estáveis. A maior parte do chumbo é retida nos solos e sedimentos e muito pouco é transportada pelas águas superficiais e subterrâneas. No entanto, o retorno para as águas superficiais como resultado da erosão de particulados do solo contendo chumbo ou através da conversão de sulfato de chumbo relativamente solúvel na superfície do solo/sedimento, pode ocorrer, assim como a lixiviação para as águas subterrâneas (LABUNSKA, STRINGER e BRIDGEN, 2000).

\subsubsection{Zn (Zinco)}

O zinco não ocorre naturalmente na forma elementar. É geralmente extraído do minério como óxido de zinco - ZnO (GWRTAC, 1997). É utilizado em revestimentos anti-corrosivos para a proteção de materiais compostos por ferro e aço, em misturas para fundições e em latão, chapas e lâminas de revestimentos de baterias elétricas, coberturas e acessórios exteriores de construções e em alguns processos de impressão (SILVA et al., 2001).

O zinco ocorre no meio ambiente principalmente no estado de oxidação $2+$, ou seja, como íon de zinco livre (hidratado) ou como complexos e compostos dissolvidos e insolúveis. Em solos, freqüentemente, permanece fortemente sorvido (LABUNSKA, STRINGER e BRIDGEN, 2000) e nas águas superficiais e subterrâneas é um dos metais mais móveis devido à formação de compostos solúveis em meio neutro a ácido (GWRTAC, 1997), na presença de ânions solúveis, ausência de matéria orgânica, argilo minerais e hidróxidos de ferro e manganês e baixa salinidade 
(LABUNSKA, STRINGER e BRIDGEN, 2000). Em valores elevados de pH, o zinco pode formar complexos de carbonatos e hidróxidos que reduzem a sua solubilidade. O zinco é facilmente precipitado sob condições redutoras e em sistemas altamente poluídos, pela co-precipitação aos óxidos de ferro e manganês (GWRTAC, 1997). A adsorção aos sedimentos e aos sólidos em suspensão nos corpos d'água, incluindo óxidos de ferro e manganês, argilo minerais e matéria orgânica, é o destino principal do zinco em ambientes aquáticos. A adsorção do zinco aumenta com o aumento do pH e diminuição da salinidade (GWRTAC, 1997).

$\mathrm{Na}$ tabela 3.3.1 apresenta-se o resumo das principais fontes e destinos dos oito principais elementos químicos caracterizados como metais pesados. 


\begin{tabular}{|c|c|c|c|c|c|c|}
\hline$\tilde{0}$ & 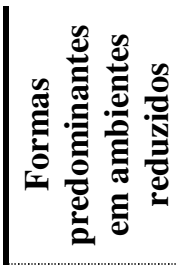 & 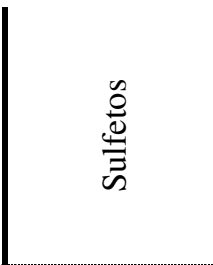 & $\frac{\pi}{0}$ & 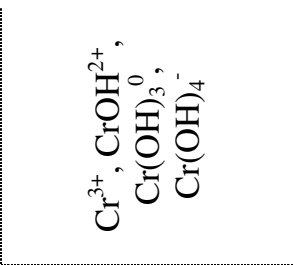 & 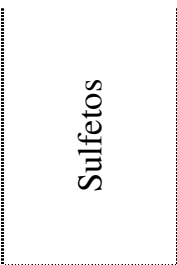 & 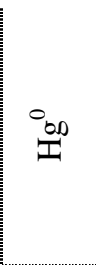 \\
\hline 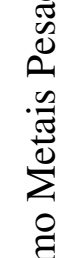 & 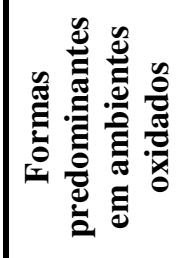 & 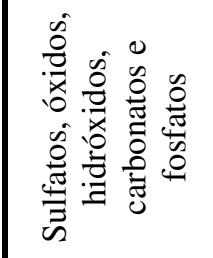 & 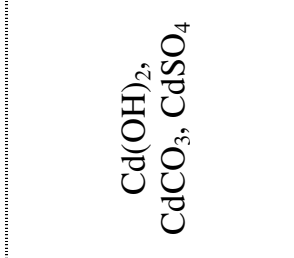 & 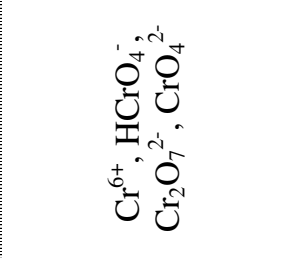 & 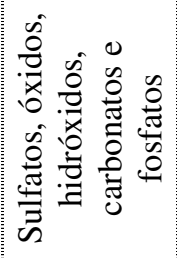 & 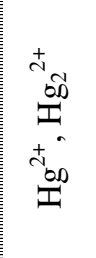 \\
\hline $\begin{array}{l}0 \\
0 \\
0 \\
0 \\
0 \\
0 \\
0 \\
0 \\
0 \\
0 \\
0\end{array}$ & 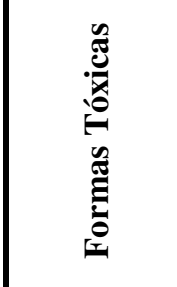 & 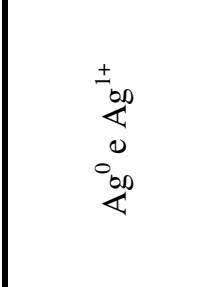 & 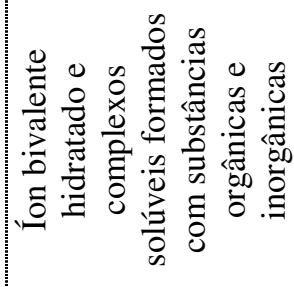 & 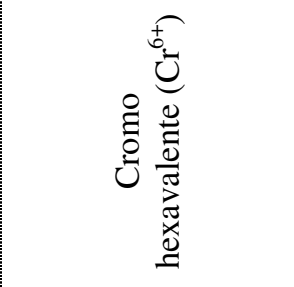 & 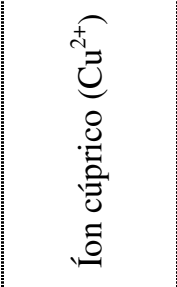 & 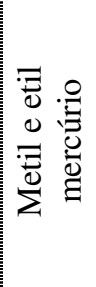 \\
\hline 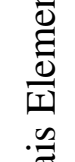 & 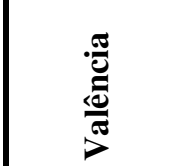 & $\begin{array}{l}+ \\
\text { m } \\
\tilde{\sigma}\end{array}$ & $\stackrel{+}{\sim}$ & $\begin{array}{l}+ \\
b \\
\sigma \\
\dot{c}\end{array}$ & $\begin{array}{l}+ \\
\tilde{\sigma} \\
\tilde{\sigma}\end{array}$ & \begin{tabular}{l}
$\stackrel{+}{ \pm}$ \\
\multirow{\sigma}{0}{}
\end{tabular} \\
\hline $\begin{array}{l}0 \\
\tilde{o} \\
0 \\
0 \\
0\end{array}$ & 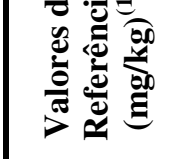 & $\begin{array}{l}\text { ñ } \\
\text { ó }\end{array}$ & $\tilde{v}$ & f & $\tilde{n}$ & $\stackrel{2}{0}$ \\
\hline 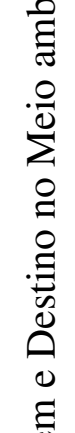 & 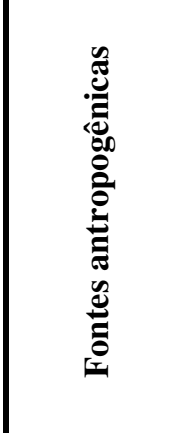 & 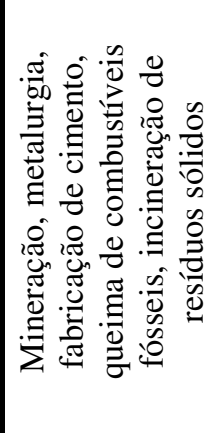 & 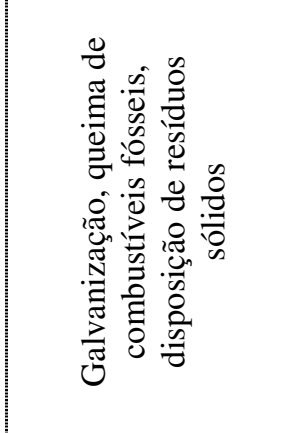 & 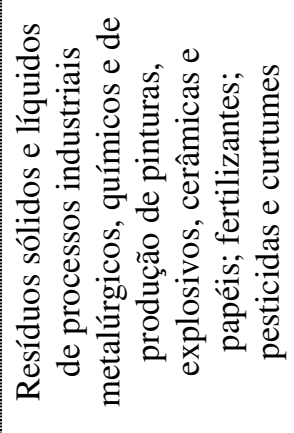 & 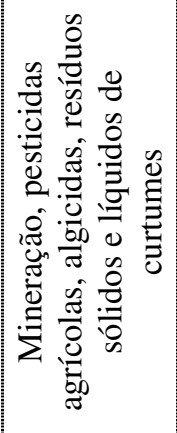 & 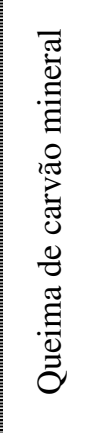 \\
\hline 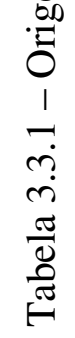 & 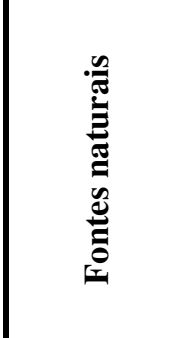 & 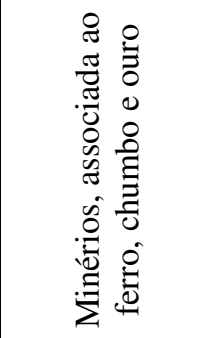 & 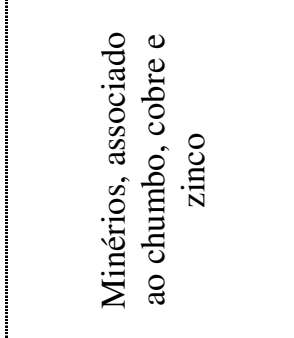 & 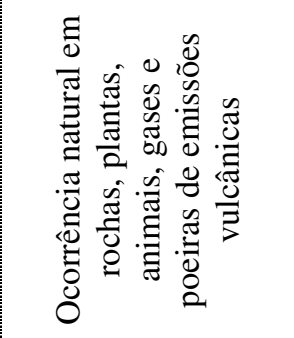 & 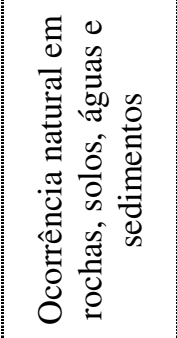 & 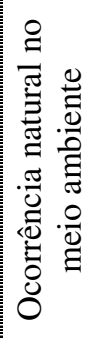 \\
\hline & 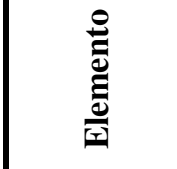 & $\stackrel{000}{\ll}$ & U & $\dot{U}$ & $\bar{U}$ & $\stackrel{600}{I}$ \\
\hline
\end{tabular}




\begin{tabular}{|c|c|c|c|}
\hline 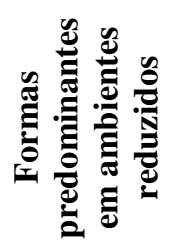 & 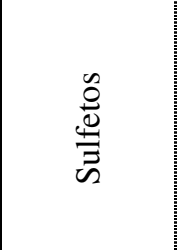 & 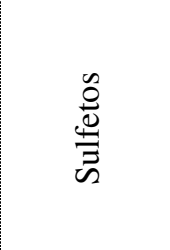 & 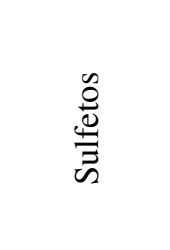 \\
\hline 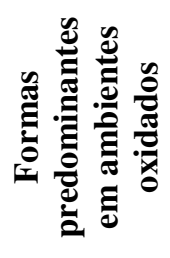 & 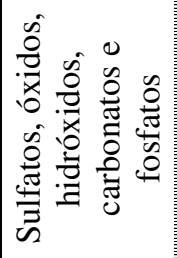 & 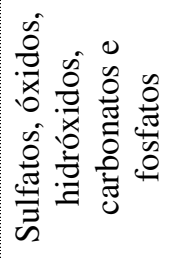 & 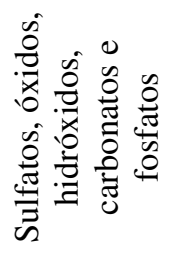 \\
\hline 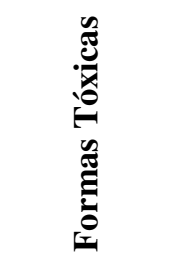 & $\stackrel{+}{\stackrel{+}{Z}}$ & 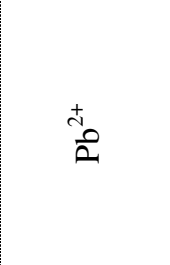 & $\stackrel{+}{\mathbb{N}}$ \\
\hline 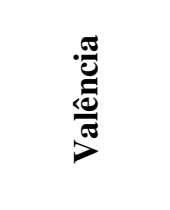 & $\begin{array}{l}+ \\
m \\
\stackrel{+}{+} \\
0 \\
0 \\
i \\
\dot{i}\end{array}$ & $\begin{array}{l}+ \\
+ \\
0 \\
\stackrel{+}{\sim}\end{array}$ & $\begin{array}{l}\stackrel{+}{\sim} \\
\stackrel{0}{0} \\
0\end{array}$ \\
\hline 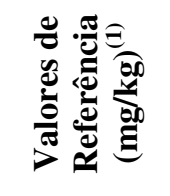 & 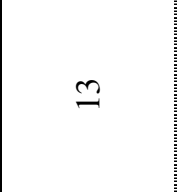 & $=$ & 8 \\
\hline 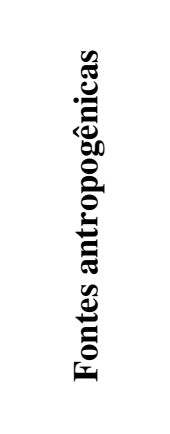 & 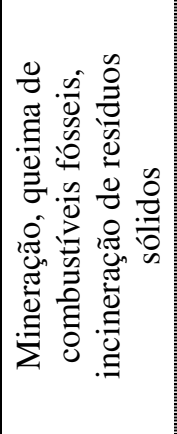 & 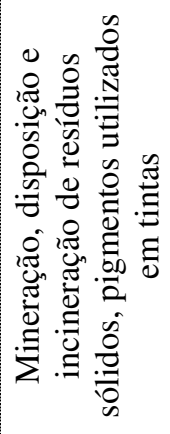 & 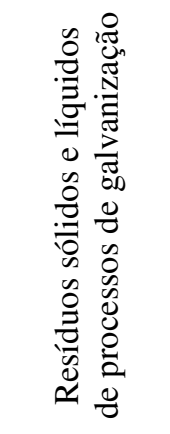 \\
\hline 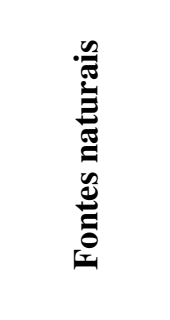 & 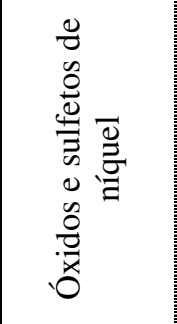 & 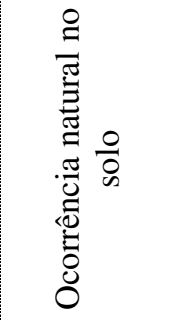 & 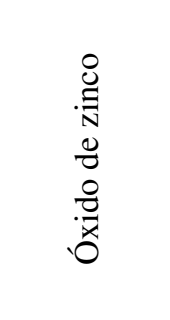 \\
\hline 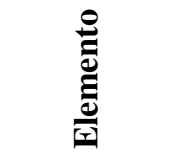 & $\bar{z}$ & $\overrightarrow{2}$ & సี \\
\hline
\end{tabular}




\subsection{Efeitos dos metais pesados no Homem e no meio ambiente}

Os metais pesados não podem ser destruídos e são altamente reativos do ponto de vista químico, o que explica a dificuldade de encontrá-los em estado puro na natureza. Normalmente, apresentam-se em concentrações muito pequenas, associados a outros elementos químicos, formando minerais em rochas. Quando lançados na água como resíduos industriais, podem ser absorvidos pelos tecidos animais e vegetais (SILVA et al., 2001).

Uma vez que os rios deságuam no mar, estes poluentes podem alcançar as águas salgadas e, em parte, depositar-se no leito oceânico. Além disso, os metais contidos nos tecidos dos organismos vivos que habitam os mares acabam também se depositando, cedo ou tarde, nos sedimentos, representando um estoque permanente de contaminação para a fauna e a flora aquáticas.

Estas substâncias tóxicas também se depositam no solo ou em corpos d'água de regiões mais distantes, graças à movimentação das massas de ar. Assim, os metais pesados podem se acumular em todos os organismos que constituem a cadeia alimentar do Homem.

A maioria dos organismos vivos só precisa de alguns poucos metais, e em doses muito pequenas, caracterizando o conceito de micronutrientes, como é o caso do zinco. Estes metais tornam-se tóxicos e perigosos para a saúde humana quando ultrapassam determinadas concentrações-limite. Já o chumbo, o mercúrio e o cádmio são metais que não existem naturalmente em nenhum organismo. Tampouco desempenham funções nutricionais ou bioquímicas em microrganismos, plantas ou animais.

No Homem, o metal pesado pode produzir vários efeitos, resultados da ação sobre moléculas, células, tecidos, órgãos ou mesmo em sistemas inteiros. Além disso, a presença de um metal pesado pode limitar a absorção de outros nutrientes essenciais à atividade do organismo. Os metais pesados, não podendo ser metabolizados, permanecem no organismo e exercem seus efeitos tóxicos, combinando-se com um ou mais grupos reativos (ligantes), os quais são indispensáveis para as funções fisiológicas normais. Dependendo do material envolvido e da intensidade da intoxicação, o efeito pode ser desde uma manifestação local na pele, membrana 
pulmonar ou trato intestinal, até efeitos mutagênicos, teratogênicos e carcinogênicos, ou mesmo a morte.

Em todas as épocas, o Homem esteve exposto aos metais pesados do meio ambiente. A época industrial e o grande desenvolvimento da indústria da mineração trouxeram o advento de doenças profissionais causadas por diversos metais tóxicos. Os ingredientes metálicos dos inseticidas e de certos agentes terapêuticos (ex: antibacterianos) são outras fontes de exposição acidental. $O$ emprego de combustíveis fósseis contendo metais pesados, o acréscimo de chumbo tetraetila na gasolina (proibido no Brasil desde 1989), e o aumento das aplicações industriais dos metais são responsáveis pelo fato de, na época atual, a poluição do meio ambiente ser a principal causa de intoxicação humana pelos metais pesados (SILVA et al., 2001).

\subsubsection{Ag (Prata)}

A exposição ocupacional à poeira contendo prata e seus compostos pode produzir a irritação do trato respiratório e gastrointestinal. Em estudo realizado com a avaliação de um grupo de 30 funcionários de uma indústria produtora de nitrato e óxido de prata, expostos a uma concentração entre 0,039 e $0,378 \mathrm{mg} \mathrm{Ag} / \mathrm{m}^{3}$ de ar, em um período variável entre 1 e 10 anos, foi detectado o desenvolvimento de irritação respiratória e dores abdominais. Um período de exposição entre 2 e 8 horas a aerossóis contendo prata coloidal produziu danos estruturais e ruptura de células da traquéia de coelhos utilizados como cobaias (US DEPARTMENT OF HEALTH AND HUMAN SERVICES, 1990).

A contagem de células do sangue foi avaliada como normal em todos os indivíduos observados em estudo de exposição ocupacional à prata realizado por ROSENMAN et al. (1979) apud US DEPARTMENT OF HEALTH AND HUMAN SERVICES (1990), exceto para o resultado do exame de um indivíduo que apresentou elevação no nível de hemoglobina. Em pesquisa realizada por PIFER et al. (1989) apud US DEPARTMENT OF HEALTH AND HUMAN SERVICES (1990), a exposição crônica de trabalhadores a compostos insolúveis de prata exibiu um pequeno decréscimo na contagem de células do sangue, assim como o aumento do volume corpuscular. No entanto, o significado toxicológico dessas evidências não é claro.

A exposição de trabalhadores em processos industriais à poeira contendo prata tem sido associada à excreção de uma enzima renal específica ( $\mathrm{N}$-acetil- $\beta$ - 
Dglucosaminidase) e à remoção da creatinina, porém, esses indivíduos também estavam expostos ao cádmio, que é um metal tóxico ao sistema renal (US DEPARTMENT OF HEALTH AND HUMAN SERVICES, 1990).

A morte de ratos utilizados como cobaias foi relacionada à ingestão de $222,2 \mathrm{mg}$ $\mathrm{Ag} / \mathrm{kg} / \mathrm{dia}$ como nitrato de prata através da água servida durante um período de 23 semanas MATUK et al. (1981) apud US DEPARTMENT OF HEALTH AND HUMAN SERVICES (1990).

A coloração acinzentada ou azul-acinzentada da pele foi observada em indivíduos que ingeriram prata e seus compostos para fins bactericidas em pequenas doses e em períodos variáveis entre meses e anos. Esse sintoma é denominado argíria. Existem relatos de casos de identificação desse sintoma em indivíduos que utilizaram excessivamente medicamentos anti-tabagistas contendo acetato de prata, soluções de nitrato de prata para o combate de doenças gengivais e cápsulas contendo nitrato de prata para a redução de desconforto gastrointestinal. As doses precisas da causa dos efeitos não foram determinadas nas investigações (US DEPARTMENT OF HEALTH AND HUMAN SERVICES, 1990).

Depósitos no Sistema Nervoso Central e conseqüente redução da atividade do sistema motor de 20 ratos expostos durante quatro meses ao nitrato de prata, presente na água ingerida, foram detectados (US DEPARTMENT OF HEALTH AND HUMAN SERVICES, 1990).

O Toxicological Profile for Silver, elaborado em dezembro de 1990 pela Agency for Toxic Substances and Disease Registry - ATSDR, pertencente ao US Department of Health and Human Services, não apresenta o $\mathrm{MRL}^{2}$ para o elemento prata.

FISCHER et al. (1984) apud US DEPARTMENT OF HEALTH AND HUMAN SERVICES (1990) reportaram fatores de bioacumulação do elemento prata em algas marinhas entre 13.000 e 66.000 vezes.

\footnotetext{
${ }^{2}$ O MRL (Minimal Risk Levels to Humans) é um índice utilizado pela Agency for Toxic Substances and Disease Registry (ATSDR) do US Department of Health and Human Services baseado na identificação do não desenvolvimento de câncer pela exposição à determinada substância. A avaliação dos efeitos à exposição pelas vias de inalação e oral é determinada para os períodos agudo (até 14 dias), intermediário (entre 15 e 364 dias) e crônico (superior a 365 dias).
} 


\subsubsection{Cd (Cádmio)}

Numerosos estudos têm identificado a morte de animais e seres humanos provocada pela inalação de vapores e poeiras contendo cádmio e seus compostos. A concentração de cádmio no ar, responsável por causar a morte em seres humanos, não foi determinada, porém os teores de cádmio quantificados nos tecidos dos pulmões foram entre 1,5 e 4,7 $\mu \mathrm{g} / \mathrm{g}$ (US DEPARTMENT OF HEALTH AND HUMAN SERVICES, 1999).

FRIBERG (1950) apud US DEPARTMENT OF HEALTH AND HUMAN SERVICES (1999) identificou a morte de duas pessoas expostas cronicamente à poeira do ar com concentrações entre 3 e $15 \mathrm{mg} \mathrm{Cd} / \mathrm{m}^{3}$. BETON et al. (1966) apud US DEPARTMENT OF HEALTH AND HUMAN SERVICES (1999) estimaram que a exposição ao ar contendo $8,63 \mathrm{mg} \mathrm{Cd} / \mathrm{m}^{3}$ durante 5 horas causou a morte de cinco indivíduos. Estudos de caso indicaram que a osteoporose e a osteomalacia (raquitismo) podem ser desenvolvidas em trabalhadores expostos durante longos períodos e a elevadas concentrações de cádmio presentes no ar (BONELL, 1955; ADAMS et al., 1969; KAZANTZIS, 1979; BLAINEY et al., 1980; SCOTT et al., 1980 apud US DEPARTMENT OF HEALTH AND HUMAN SERVICES, 1999) e em alimentos contaminados.

Há fortes evidências de que o sistema renal é o principal alvo da toxicidade do cádmio no organismo humano, exposto à inalação e ingestão desse elemento e seus compostos. Os teores de cádmio presentes no córtex renal, associados à incidência da disfunção desse órgão em população adulta exposta cronicamente aos vapores e poeiras contendo cádmio, foi determinada em $200 \mu \mathrm{g} \mathrm{Cd} / \mathrm{g}$ em vários estudos (FRIBERG et al., 1974; KJELLSTROM et al., 1977a, 1984; ROELS et al., 1983 apud US DEPARTMENT OF HEALTH AND HUMAN SERVICES, 1999).

A ingestão intencional de uma dose de $25 \mathrm{mg} \mathrm{Cd} / \mathrm{kg}$ na forma de iodeto de cádmio por dois indivíduos foi relatada como causadora de morte por WISNIEWSKAKNYPL et al., (1971) e $1.840 \mathrm{mg} \mathrm{Cd} / \mathrm{kg}$ como cloreto de cádmio por BUCKLER et al. (1986) apud US DEPARTMENT OF HEALTH AND HUMAN SERVICES (1999).

Vários estudos indicaram severas irritações no epitélio gastrointestinal de animais e seres humanos que ingeriram elevadas concentrações de cádmio, porém as doses 
precisas não foram determinadas. A ingestão de cádmio reduz a absorção de ferro pelo sistema gastrointestinal, a qual pode produzir a anemia. A hipoprotoinemia e a hipoalbuminemia foram identificadas em um indivíduo que ingeriu $25 \mathrm{mg} \mathrm{Cd} / \mathrm{kg}$ na forma de iodeto de cádmio (WISNIEWSKA-KNYPL et al., 1971 apud US DEPARTMENT OF HEALTH AND HUMAN SERVICES, 1999).

Estudos relataram acúmulo em animais aquáticos em concentrações de centenas ou, até mesmo, milhares de vezes mais altas do que na água. Os fatores de bioconcentração relatados variaram entre 113 a 18.000 para invertebrados e de 3 a 2.213 para peixes (LABUNSKA, STRINGER e BRIDGEN, 2000).

Para o cádmio, foi identificado o MRL para a exposição oral e período crônico (US DEPARTMENT OF HEALTH AND HUMAN SERVICES, 1999): 0,0002 $\mathrm{mg} / \mathrm{kg} / \mathrm{dia}$ - efeitos renais.

A USEPA (United States Environmental Protection Agency) classificou o elemento cádmio como provável carcinogênio e estabeleceu a dose de referência de $5 \times 10^{-4}$ $\mathrm{mg} / \mathrm{kg} /$ dia para a água e $1 \times 10^{-3} \mathrm{mg} / \mathrm{kg} /$ dia para a comida (US DEPARTMENT OF HEALTH AND HUMAN SERVICES, 1999).

Para o cobre foi identificado o MRL para a via de exposição oral e período crônico (US DEPARTMENT OF HEALTH AND HUMAN SERVICES, 1999):

MRL (exposição oral e período crônico): 0,0002 mg/kg/dia - efeitos renais.

\subsubsection{Cr (Cromo)}

O cromo trivalente é considerado um metal traço, necessário para o metabolismo de glicose, proteínas e lipídios em mamíferos. Os sinais de deficiência em seres humanos incluem perda de peso e diminuição da tolerância à glicose. As exigências mínimas diárias de cromo trivalente para uma boa saúde não são conhecidas, mas estima-se que uma ingestão diária entre 50 e $200 \mu \mathrm{g} / \mathrm{dia}$ seja segura e adequada (LABUNSKA, STRINGER e BRIDGEN, 2000).

Os compostos de cromo hexavalente têm sido caracterizados como mais tóxicos à saúde humana do que os compostos trivalentes, devido às propriedades carcinogênicas, irritativas e corrosivas (CHIMTHAMREDDY e REDDY, 1999).

O cromo hexavalente é carcinogênico e mutagênico para os seres humanos e animais, o que resulta em alterações na pele, olhos e mucosas (TURICK, GRAVES e APEL, 1998). 
Os compostos de cromo hexavalente são corrosivos e reações alérgicas na pele ocorrem logo após o contato, independente da dose. Exposições breves a níveis elevados podem resultar na ulceração da pele exposta, perfurações no trato respiratório e na irritação do trato gastrointestinal. Danos ao rim e ao fígado também foram relatados. Além disso, em 1998, a Agência Internacional de Pesquisa em Câncer classificou os compostos de cromo hexavalente como carcinogênicos (LABUNSKA, STRINGER e BRIDGEN, 2000).

Para os compostos de cromo em aerossóis e particulados, foram identificados os MRLs para a via de exposição por inalação e período intermediário (US DEPARTMENT OF HEALTH AND HUMAN SERVICES, 2000):

MRL para compostos de cromo em aerossóis (exposição por inalação e período intermediário): $0,000005 \mathrm{mg} / \mathrm{m}^{3}$ - efeitos respiratórios.

MRL para compostos de cromo particulados (exposição por inalação e período intermediário): $0,001 \mathrm{mg} / \mathrm{m}^{3}$ - efeitos respiratórios.

\subsubsection{Cu (Cobre)}

O cobre é um nutriente essencial, incorporado a grande número de metaloenzimas envolvidas na formação da hemoglobina, metabolismo de carboidratos, formação da melanina e na ligação cruzada entre colágenos, elastina e queratina dos cabelos. Os sintomas associados à deficiência do cobre em seres humanos são a anemia, leucopenia e osteoporose. A dieta diária de cobre recomendada de 0,9 mg/dia (0,013 $\mathrm{mg} / \mathrm{kg} / \mathrm{dia}$ ) foi recentemente estabelecida (US DEPARTMENT OF HEALTH AND HUMAN SERVICES, 2002).

A inalação de poeira e vapores contendo compostos de cobre pode irritar o nariz, a boca e os olhos e causar dores de cabeça, tontura, náusea e diarréia. A exposição oral a níveis elevados pode causar vômito, diarréia, cólica estomacal e náusea (LABUNSKA, STRINGER e BRIDGEN, 2000).

O fígado humano é um órgão sensível à toxicidade produzida pelo cobre. Os danos a esse órgão (necrose e fibrose) foram observados em indivíduos que ingeriram intencionalmente doses letais de sulfato de cobre (US DEPARTMENT OF HEALTH AND HUMAN SERVICES, 2002).

Foram observadas a inflamação e necrose do fígado de ratos que foram alimentados com sulfato de cobre em teores 100 vezes mais elevados do que a necessidade 
nutricional diária. Estudos realizados em ratos expostos pela dieta diária com elevados teores de cobre identificaram o retardamento no crescimento embrionário e fetal (US DEPARTMENT OF HEALTH AND HUMAN SERVICES, 2002).

Existem algumas evidências produzidas por estudos em animais que sugeriram danos ao sistema imunológico pela exposição a elevados níveis de cobre presentes no ar atmosférico. A carcinogenicidade do cobre não foi adequadamente estudada. $O$ aumento do risco de câncer foi identificado em trabalhadores de fundições, porém, foi atribuído à exposição concomitante ao arsênio. A Agência Internacional de Pesquisa em Câncer classificou o cobre 8-hidróxiquinolina no Grupo 3 e a USEPA no grupo $\mathrm{D}$, ambos indicam o não desenvolvimento de câncer nos organismos expostos aos compostos desse elemento (US DEPARTMENT OF HEALTH AND HUMAN SERVICES, 2002).

A homeostase do cobre desempenha um papel importante na prevenção da toxicidade em seres humanos, animais terrestres e organismos aquáticos. O cobre é facilmente absorvido pelo estômago e intestino delgado. Após o atendimento das exigências metabólicas, o excesso de cobre pode ser excretado pela bile e armazenado no fígado ou na medula óssea. No entanto, falhas no mecanismo homeostático podem ocorrer em seres humanos e animais após a exposição a elevados níveis de cobre, sendo a doença rara de Wilson, caracterizada pela retenção excessiva de cobre no fígado e excreção deficiente pela bile, consequentemente, resultando em danos ao fígado e rins e anemia hemolítica (LABUNSKA, STRINGER e BRIDGEN, 2000).

A toxicidade aquática do cobre é bem estudada, e há evidências experimentais de que um número considerável de espécies é sensível a concentrações entre 1 e $10 \mu \mathrm{g} / \mathrm{L}$ (LABUNSKA, STRINGER E BRIDGEN, 2000).

Para o cobre, foram identificados os MRLs para a via de exposição oral e períodos agudo e intermediário (US DEPARTMENT OF HEALTH AND HUMAN SERVICES, 2002):

MRL (exposição oral e período agudo): 0,02 mg/kg/dia - efeitos gástricos.

MRL (exposição oral e período intermediário): 0,03 mg/kg/dia - efeitos hepáticos.

\subsubsection{Hg (Mercúrio)}

Durante séculos, o mercúrio foi um ingrediente importante de numerosos medicamentos, tais como diuréticos, bactericidas, anti-sépticos, laxantes e ungüentos. 
No decorrer das últimas décadas, os compostos mercuriais foram substituídos por métodos de tratamento mais específicos e eficazes, de modo que os sinais de intoxicação mercurial devido às drogas tornaram-se raridade. Por outro lado, vêm preocupando os casos de intoxicação mercurial devidos à poluição do meio ambiente (SILVA et al., 2001).

Os efeitos da bioacumulação do mercúrio no meio ambiente ocorrem pela conversão do metal em metilmercúrio pelos microrganismos aquáticos, que é uma forma mais tóxica do que as formas inorgânicas. Esse composto é absorvido pelo fitoplâncton e concentrado nos peixes através da cadeia alimentar. Dessa forma, as concentrações encontradas nos peixes são muito maiores do que as originalmente inseridas no meio ambiente (CÂMARA et al., 1997). As concentrações em peixes carnívoros no topo das cadeias alimentares (como o lúcio, o atum, e o peixe-espada) são biomagnificadas entre 10.000 e 100.000 vezes comparando-se às concentrações encontradas em águas doces e salgadas. A importância dessa bioacumulação é que ela geralmente é a fonte mais importante de exposição humana não-ocupacional ao mercúrio (LABUNSKA, STRINGER e BRIDGEN, 2000).

Em relação à toxicidade, três formas do metal são principalmente distinguidas: vapor de mercúrio (mercúrio elementar), sais de mercúrio (mercúrio inorgânico) e mercuriais orgânicos (CÂMARA et al., 1997).

O mercúrio elementar é a mais volátil das formas inorgânicas do metal. A exposição humana ao vapor de mercúrio é principalmente ocupacional. A exposição crônica ao mercúrio ocorrida em laboratórios científicos ou em atividades de extração de ouro pode produzir efeitos tóxicos. O vapor de mercúrio também pode ser liberado da amálgama utilizada em restaurações odontológicas, mas a quantidade liberada não causa efeitos tóxicos à saúde humana.

O mercúrio metálico não é particularmente tóxico quando ingerido porque é muito pouco absorvido pelo trato gastrointestinal. No entanto, a inalação do vapor de mercúrio é completamente absorvida pelos pulmões e então oxidado à mercúrio divalente pela catálise nos eritrócitos.

O Sistema Nervoso Central é mais exposto ao vapor de mercúrio do que ao mercúrio divalente. A excreção do metal é realizada pela urina e fezes e a meia vida do mercúrio elementar é de aproximadamente 60 dias. 
Um curto período de exposição ao vapor de mercúrio pode produzir sintomas em poucas horas, como fraqueza, calafrios, sabor metálico, náuseas, vômitos, dispnéia e tosse.

A exposição crônica ao vapor de mercúrio produz efeitos neurológicos. Os sintomas iniciais incluem a anorexia, perda de peso, distúrbios gastrointestinais, timidez, perda de memória, insônia e em casos graves, delírios (CÂMARA et al., 1997).

Para os compostos de mercúrio (vapor de mercúrio metálico e cloreto de mercúrio), foram identificados os MRLs para a via de exposição por inalação e oral e períodos agudo, intermediário e crônico (US DEPARTMENT OF HEALTH AND HUMAN SERVICES, 1999):

MRL vapor de mercúrio (exposição por inalação e crônica): $0,0002 \mathrm{mg} / \mathrm{m}^{3}$ - efeitos neurológicos.

MRL cloreto de mercúrio (exposição oral e aguda): 0,007 mg/kg/dia - efeitos renais. MRL cloreto de mercúrio (exposição oral e intermediária): 0,002 mg/kg/dia - efeitos renais.

\subsubsection{Ni (Níquel)}

Os efeitos da intoxicação humana por exposição aguda a esse metal ocorrem em duas etapas (SILVA et al., 2001): inicialmente aparecem náuseas, dor de cabeça, vertigens, vômito, insônia e irritabilidade. Depois, dores no peito, fraqueza, dispnéia, cianose, taquicardia, além de distúrbios visuais e transpiração. Em casos letais, foram observadas hemorragia pulmonar, edema ou pneumonite, acompanhadas de desarranjo de células alveolares. Em outros casos, foram observados edema cerebral e hemorragias pontuais no cérebro após a inalação de níquel carbonila. Efeitos nefrotóxicos foram observados em casos de exposição acidental ao níquel carbonila e ingestão acidental de sais de níquel.

Os órgãos humanos normalmente afetados pela ingestão desse metal pesado são: o fígado, rim, baço, pulmão e cérebro. Os danos ao aparelho respiratório vão desde rinites, sinusites e asma até, em alguns casos, câncer nasal e pulmonar. Casos de câncer no seio e aberrações cromossômicas também foram relatados (SILVA et al., 2001).

Para o níquel foi identificado o MRL para a via de exposição por inalação e crônica (US DEPARTMENT OF HEALTH AND HUMAN SERVICES, 2003): 
MRL (exposição por inalação e período crônico): $0,0002 \mathrm{mg} / \mathrm{m}^{3}$ - efeitos respiratórios.

\subsubsection{Pb (Chumbo)}

Alguns casos isolados de intoxicação pelo chumbo têm sido atribuídos a fontes diversas, tais como brinquedos feitos de chumbo, poeira de chumbo nas galerias de tiro ao alvo, pigmentos usados nas tintas para artistas, cinzas e fumaças de madeira pintada, resíduos das oficinas de joalheiros, fabricação caseira de baterias e tubulação de chumbo (SILVA et al., 2001).

O chumbo presente no solo e na poeira, em teores entre 500 e $1.000 \mathrm{mg} / \mathrm{kg}$, pode afetar a saúde de crianças. Uma análise detalhada de 12 estudos epidemiológicos mostrou que $5,9 \%$ das crianças norte-americanas possuíam mais do que $10 \mu \mathrm{g} \mathrm{Pb} / \mathrm{dL}$ no sangue. Esse valor é o limiar da concentração que pode produzir neurotoxicidade (MERCIER, DUCHESNE e CARLES-GIBERGUES, 2002).

O chumbo é um dos metais pesados mais presentes no meio ambiente e não possui função nutricional, bioquímica ou fisiológica conhecida. Os efeitos tóxicos do chumbo são os mesmos, independente da forma de exposição (oral ou inalação), sendo que os níveis no sangue inferiores a 10 a $100 \mu \mathrm{g} / \mathrm{dL}$ em crianças e a partir de 10 a $100 \mu \mathrm{g} / \mathrm{dL}$ em adultos foram associados a uma série de efeitos adversos, como distúrbios no sistema nervoso, anemia e diminuição da síntese da hemoglobina, doença cardiovascular, além de distúrbios no metabolismo ósseo, na função renal e na reprodução. $\mathrm{O}$ efeito de uma exposição relativamente baixa no desenvolvimento cognitivo e comportamental em crianças é extremamente preocupante (LABUNSKA, STRINGER e BRIDGEN, 2000).

Em 1975, o Centro de Controle de Doenças (CDC) em Atlanta (EUA) recomendou que o nível permissível de chumbo no sangue fosse de $30 \mu \mathrm{g} / \mathrm{dL}$ (para adultos e crianças). Esses níveis foram reduzidos em 1985 para $25 \mu \mathrm{g} / \mathrm{dL}$ e novamente em 1991, para $10 \mu \mathrm{g} / \mathrm{L}$. Mais importante é a recomendação atual de que talvez não haja níveis aceitáveis de chumbo no sangue que não produzam efeitos tóxicos, especialmente no sistema nervoso central em desenvolvimento (LABUNSKA, STRINGER e BRIDGEN, 2000). 
Plantas e animais podem acumular chumbo a partir da água, dos solos e sedimentos, sendo as formas orgânicas mais facilmente absorvidas do que as inorgânicas (LABUNSKA, STRINGER e BRIDGEN, 2000).

Estudos em animais reproduziram muitos dos efeitos tóxicos listados anteriormente, e foram relatados o envenenamento e morte daqueles que se alimentaram em locais próximos a indústrias de fundição, mineração e reciclagem de metais (LABUNSKA, STRINGER e BRIDGEN, 2000).

O chumbo é também tóxico para toda a biota aquática, e, embora não seja considerado um dos metais de maior mobilidade no meio ambiente, ainda há evidências consideráveis mostrando a sua biodisponibilidade em sedimentos para espécies que se alimentam de detritos. Além disso, o chumbo pode ser acumulado diretamente de águas salgadas e doces, especialmente em organismos filtradores que utilizam as brânquias como a principal rota de ingestão de nutrientes. Estudos toxicológicos apontaram efeitos sub-letais em peixes, incluindo mudanças na morfologia, no metabolismo e em atividades enzimáticas. O comportamento de evitação (comportamento através do qual alguns animais aquáticos são capazes de evitar áreas com concentrações anormais de substâncias nocivas) também foi observado em peixes adultos expostos a níveis entre 10 e $100 \mathrm{mg} \mathrm{Pb} / \mathrm{L}$ (LABUNSKA, STRINGER e BRIDGEN, 2000).

\subsubsection{Zn (Zinco)}

Os efeitos tóxicos da exposição pela inalação do zinco e seus compostos variam conforme a espécie química presente (US DEPARTMENT OF HEALTH AND HUMAN SERVICES, 2003).

Após a inalação do óxido de zinco, o efeito adverso mais freqüentemente identificado é denominado febre do vapor metálico. Esse efeito é caracterizado pelos sintomas de dores no peito, tosse, dispnéia, redução do volume dos pulmões, náuseas e leucocitose. Os sintomas geralmente surgem após poucas horas e são reversíveis entre 1 e 4 dias ao término da exposição. Os níveis precisos de exposição associados ao desenvolvimento da febre do vapor metálico não foram identificados, porém estão na faixa de 200 a $500 \mathrm{mg} / \mathrm{m}^{3}$ (US DEPARTMENT OF HEALTH AND HUMAN SERVICES, 2003). 
Experimentos realizados com a exposição a baixas concentrações de óxido de zinco a curto prazo (14 mg/m $\mathrm{m}^{3}$ em 8 horas ou $45 \mathrm{mg} / \mathrm{m}^{3}$ em 20 minutos) e exposições ocupacionais a concentrações similares $\left(8\right.$ a $12 \mathrm{mg} / \mathrm{m}^{3}$ entre 1 e 3 horas e 0,034 $\mathrm{mg} / \mathrm{m}^{3}$ entre 6 e 8 horas) não produziram sintomas da febre do vapor metálico. No entanto, a inalação do cloreto de zinco geralmente resulta em danos nas mucosas do trato respiratório, mais perceptíveis com a produção dos sintomas de dispnéia, tosse e pneumonia (US DEPARTMENT OF HEALTH AND HUMAN SERVICES, 2003). A exposição oral entre 2 e $8 \mathrm{mg} / \mathrm{kg} / \mathrm{dia}$ aos compostos de zinco em até 14 dias, geralmente, produz efeitos gastrointestinais e o surgimento de sintomas como náuseas, vômitos, dores abdominais e diarréia. A ingestão de cloreto de zinco pode produzir queimaduras no trato gastrointestinal, particularmente na boca, esôfago e estômago (US DEPARTMENT OF HEALTH AND HUMAN SERVICES, 2003).

Após longo período de exposição a baixas concentrações de compostos de zinco

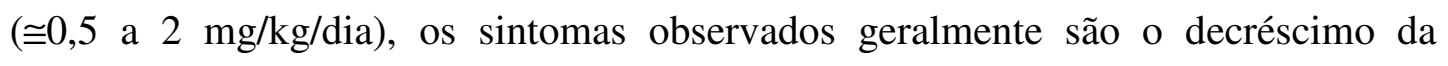
absorção do cobre ingerido pela dieta diária e conseqüente deficiência de cobre no organismo. A manifestação mais conhecida da deficiência do cobre é a anemia, na qual tem sido relatada em muitos estudos de suplementação de zinco em organismos de seres humanos. Alguns estudos têm associado o aumento da exposição ao zinco e seus compostos ao decréscimo dos níveis das lipoproteínas de alta densidade (HDL) nos organismos humanos (US DEPARTMENT OF HEALTH AND HUMAN SERVICES, 2003).

Devido à essencialidade do zinco, recomenda-se a ingestão diária de $15 \mathrm{mg} /$ dia para homens e $12 \mathrm{mg} /$ dia para mulheres. O consumo diário de suplementos alimentares contendo zinco acima das doses recomendadas, que variam entre 400 e $500 \mathrm{mg} / \mathrm{dia}$, pode produzir sérias gastroenterites (LABUNSKA, STRINGER e BRIDGEN, 2000). Geralmente, o contato dérmico aos compostos de zinco não produz qualquer efeito tóxico. No entanto, a exposição dérmica ao cloreto de zinco pode resultar em severa irritação da pele (US DEPARTMENT OF HEALTH AND HUMAN SERVICES, 2003).

Os estudos existentes não produziram evidências de efeitos danosos ao desenvolvimento e reprodução dos seres humanos e animais devido à exposição pela inalação de compostos de zinco. Os efeitos maléficos ao desenvolvimento ou 
reprodução de animais foram observados em pesquisas realizadas com a exposição oral e doses superiores a $200 \mathrm{mg} / \mathrm{kg} / \mathrm{dia}$ (US DEPARTMENT OF HEALTH AND HUMAN SERVICES, 2003).

As pesquisas realizadas não são suficientes para indicar a produção de efeitos carcinogênicos em seres humanos e animais após a exposição oral aos compostos de zinco em longo período de tempo (US DEPARTMENT OF HEALTH AND HUMAN SERVICES, 2003).

Estudos em plantas mostraram que, embora seja um elemento essencial para as de grande porte, em concentrações elevadas, o zinco é considerado fitotóxico, afetando diretamente a produção de culturas e a fertilidade do solo. Teores de zinco no solo variando de 70 e $400 \mathrm{mg} / \mathrm{kg}$ são classificados como críticos, acima dos quais a toxicidade é considerada provável (LABUNSKA, STRINGER e BRIDGEN, 2000).

Para o zinco, foram identificados os MRLs para a via de exposição oral e períodos intermediário e crônico (US DEPARTMENT OF HEALTH AND HUMAN SERVICES, 2003):

MRL (exposição oral e período intermediário): $0,3 \mathrm{mg} / \mathrm{kg} / \mathrm{dia}$ - efeitos hematológicos.

MRL (exposição oral e crônica): 0,3 mg/ $\mathrm{kg} / \mathrm{dia}$ - efeitos dermatológicos.

$\mathrm{Na}$ tabela 3.4.1, é mostrado o resumo dos efeitos tóxicos ao Homem produzidos pelos principais elementos caracterizados como metais pesados. 
$\approx$

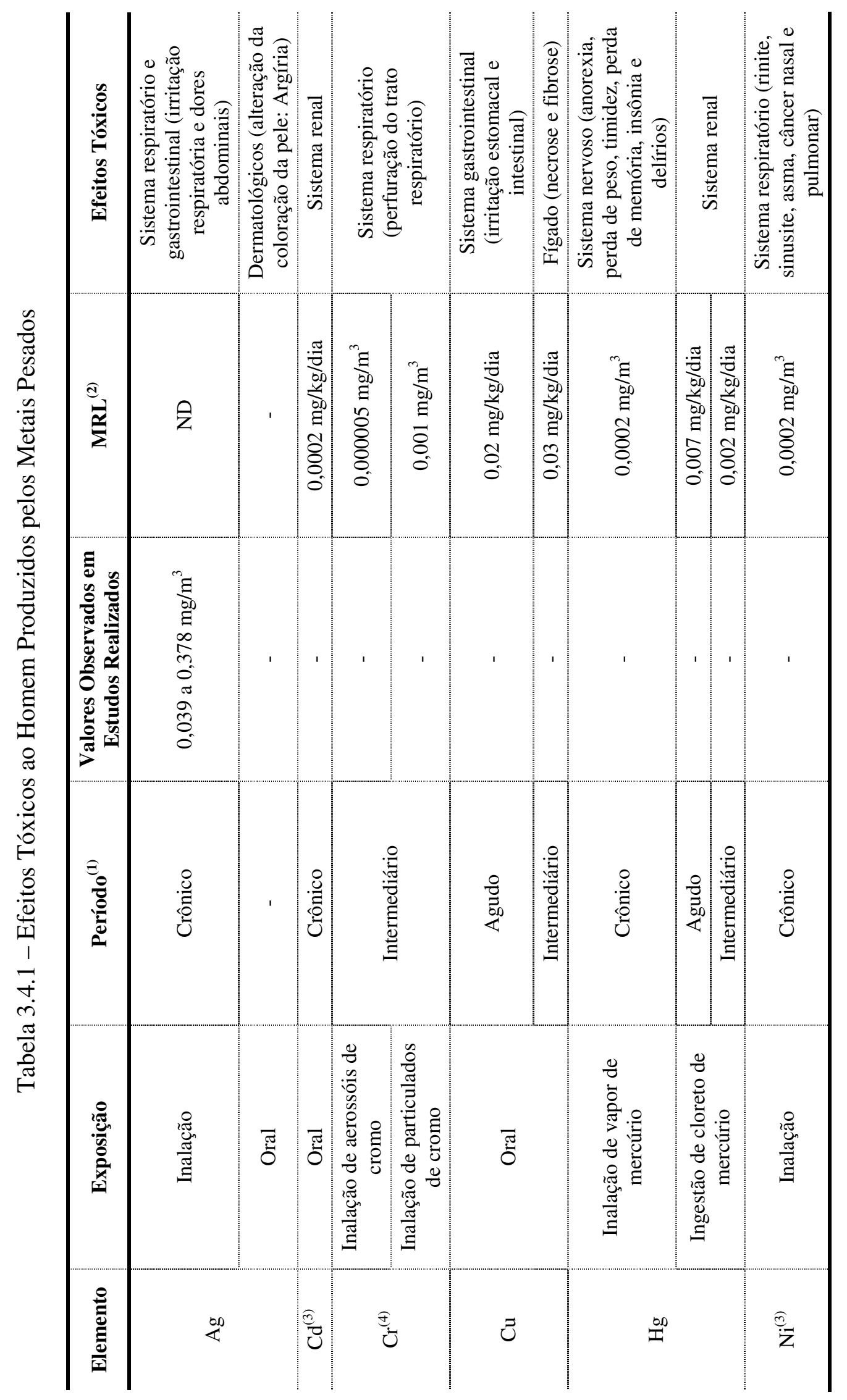


$m$

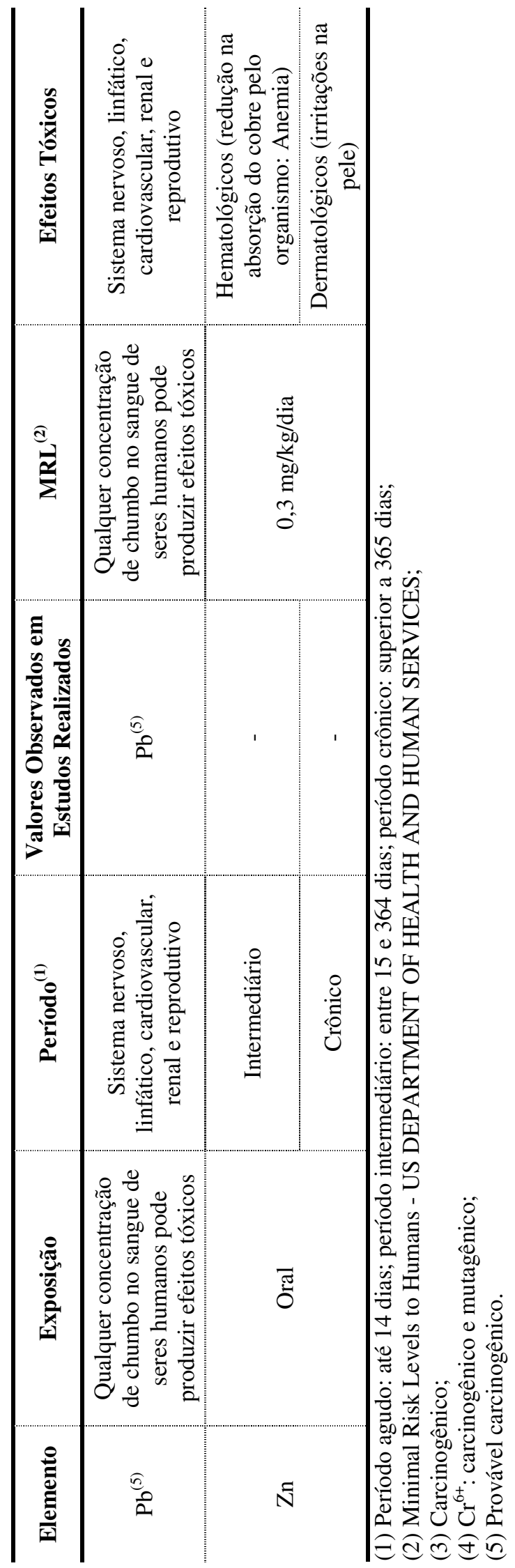




\subsection{Tecnologias de remediação de áreas contaminadas por metais pesados}

A contaminação por metais pesados ocorre em três formas na matriz sólida (GWRTAC, 1997):

- contaminantes solúveis na mistura do solo;

- contaminantes adsorvidos à superfície do solo;

- contaminantes fixos quimicamente como compostos insolúveis.

As características químicas e físicas do solo influenciam a forma do metal. Entre as propriedades químicas, a presença de ânions inorgânicos (carbonatos, fosfatos e sulfetos) na água intersticial pode influenciar a habilidade do solo em fixar quimicamente os metais pesados. Esses ânions podem formar complexos relativamente insolúveis com os íons metálicos e produzir a dessorção e/ou precipitação.

$\mathrm{O}$ pH do solo geralmente varia entre 4,0 e 8,5. Os cátions metálicos são mais móveis em condições ácidas (GWRTAC, 1997) e em solos arenosos (USEPA, 1997), enquanto os ânions tendem a sorver aos óxidos minerais nessa faixa de $\mathrm{pH}$.

Em pH elevado, a mobilização dos cátions e ânions metálicos ocorre pela precipitação e solubilização, respectivamente.

Sob condições atípicas dos solos, possivelmente existentes na ocorrência da disposição inadequada de resíduos sólidos e após processos de remediação $(\mathrm{pH}<5$ ou >9); elevadas concentrações de substâncias redutoras ou oxidantes, orgânicas ou inorgânicas complexadas solúveis e substâncias coloidais), a mobilidade dos metais pesados pode ser substancialmente reduzida (USEPA, 1997).

A presença de óxidos metálicos de $\mathrm{Al}, \mathrm{Fe}$ e $\mathrm{Mn}$ influenciam fortemente na concentração dos metais pesados, pois esses minerais podem remover cátions e ânions da solução pela troca iônica, especificamente pela adsorção e precipitação. A capacidade de troca catiônica (CTC) é a concentração de cátions prontamente trocáveis presentes na superfície de um mineral e é freqüentemente utilizada para indicar a capacidade dos solos em reter cátions como os íons metálicos. A capacidade de troca aniônica (CTA) indica a capacidade dos solos em reter ânions e geralmente é menor do que a capacidade de troca catiônica dos solos. Além dos óxidos, as argilas são importantes materiais de troca iônica para os metais (GWRTAC, 1997). 
A presença de matéria orgânica influi na sorção de íons metálicos à superfície dos minerais, particularmente, os materiais húmicos podem complexar e afetar a remoção da solução.

As propriedades físicas, como a distribuição do tamanho das partículas pode determinar o grau de contaminação do solo por metais pesados. Partículas finas $(<$ $100 \mu \mathrm{m})$ são mais reativas e possuem maior área superficial do que as partículas grosseiras. Como resultado, a fração fina do solo geralmente contém a maior parte da contaminação.

A composição influencia na química do solo contaminado, pois determina a quantidade de minerais dissolvidos e valores do $\mathrm{pH}$ e do potencial redox presentes na água intersticial do solo.

A estrutura do solo influi na mobilidade dos contaminantes através da limitação do contato entre as águas subterrâneas e os contaminantes (GWRTAC, 1997).

As tecnologias de remediação de áreas contaminadas por metais pesados podem ser agrupadas em biológicas, físico-químicas e térmicas e aplicáveis na própria área (in situ) ou ex situ, pelo tratamento do solo escavado.

\subsubsection{Biológicas}

Os processos de tratamento biológico ocorrem através de vários mecanismos que incluem a adsorção, reações de óxido-redução e a metilação, produzidos pelas atividades de microrganismos e plantas (GWRTAC, 1997).

\subsubsection{Bioacumulação}

Esse processo envolve a captura dos metais pesados do solo contaminado pelos organismos e biomassa inativa. Os vegetais e microrganismos acumulam metais pesados como resultado do processo metabólico de troca iônica e reações de complexação nas membranas celulares, ou pela precipitação intra ou extracelular. A adsorção dos metais pesados à superfície das células dos organismos é o primeiro mecanismo de retenção produzido pela biomassa inativa (GWRTAC, 1997).

As bactérias gram-positivas apresentam porcentagem de bioacumulação de metais pesados em suas células $30 \%$ superior do que as gram-negativas (GOURDON et al., 1990 apud TAKAMATSU, 1995). 
$\mathrm{Na}$ fitorremediação, ou seja, a extração de metais pesados de solos e sedimentos através da utilização de vegetais, os elementos cádmio, chumbo, cobre e níquel, são acumulados em altas concentrações na biomassa de determinadas espécies. Foi relatado por HAASE (1988), BAKER et al. (1991) apud RULKENS, GROTENHUIS e TICHÝ (1995), a utilização de espécies nativas de clima moderado europeu, como a Polygonum sachalinese, Thlaspi, Alyssum, Urtica e Chenopodium.

Os processos de fitorremediação podem ocorrer pela fitoextração, fitoestabilização e rizofiltração (USEPA, 1996b).

- Fitoextração: emprega plantas hiperacumuladoras para a remoção de metais pesados do solo pela absorção pelas raízes e brotos. Uma planta hiperacumuladora é definida como aquela que possui a capacidade de reter $\geq$ $0,1 \%$ de cobalto, cobre, cromo ou níquel ou $\geq 1 \%$ de manganês ou zinco em seus brotos (massa em base seca), localizados acima da superfície do solo.

- Fitoestabilização: utilização de plantas para a limitação da mobilidade e disponibilidade dos metais pesados no solo. As plantas fitoestabilizadoras são caracterizadas pela alta tolerância aos metais pesados presentes no solo e baixa capacidade de acumulação desses elementos.

- Rizofiltração: utilizada para a adsorção de metais pesados, presentes em áreas contaminadas, pelas raízes das plantas.

Alguns aspectos devem ser considerados na utilização de plantas acumuladoras de metais pesados (RULKENS, GROTENHUIS e TICHÝ, 1995):

- Seleção de espécies apropriadas (hiperacumuladoras) às condições climáticas, tipo de solo, contaminação e ao processo posterior de tratamento da biomassa;

- Avaliação da poluição do solo por metais pesados, especialmente as características físico-químicas do solo contaminado. $\mathrm{O}$ conhecimento da biodisponibilidade do metal a ser extraído é fundamental para a verificação da eficiência do processo de bioacumulação;

- Adoção de medidas de proteção contra a dispersão da biomassa contaminada no meio ambiente, evitando riscos à vida selvagem e à produção agrícola;

- Técnicas de remoção dos metais pesados da biomassa contaminada: devido à elevada concentração de metais pesados no corpo das plantas, exclui-se a utilização da biomassa para fins agrícolas. No entanto, várias técnicas são 
utilizadas para a remoção dos metais pesados das plantas, como os métodos térmicos (secagem, incineração, gasificação e pirólise); físico-químicos (extração dos metais pesados acumulados na biomassa com a utilização de ácidos minerais); biológicos (digestão anaeróbia do resíduo, utilizado como prétratamento); remoção de metais pesados através de processos tecnológicos de utilização da biomassa para obtenção de produtos como a clorofila, óleos, fibras, etc.; disposição (utilizada para compostos altamente tóxicos, como metais radioativos e se os fatores de acumulação são suficientemente elevados).

\subsubsection{Biolixiviação}

Processo que utiliza microrganismos para a solubilização dos metais pesados presentes em solos contaminados através da ação direta de bactérias e/ou como resultado da interação de produtos metabólicos (GWRTAC, 1997). Esse processo foi adaptado da indústria minerária para a utilização na remediação de solos contaminados por metais pesados.

Segundo LLOYD (2002), os metais podem ser extraídos de meios contaminados através de dois mecanismos. Primeiro, os microrganismos heterótrofos podem mobilizar metais via produção de ácidos orgânicos. Alternativamente, a bactéria da espécie Acidithiobacillus sp. pode gerar significativas quantidades de ácido sulfúrico com metal lixiviado pela oxidação do enxofre elementar. Este mecanismo de mobilização de metais tem sido utilizado por muitos séculos para a lixiviação de metais de minérios e atualmente suporta um lucrativo mercado global de extração mineral. Essa prática também pode ser utilizada para a descontaminação de solos e sedimentos por metais pesados e pode ser combinada com um segundo mecanismo, ex situ, para a remoção de metais como sulfetos insolúveis usando bactérias sulfo redutoras, o qual reverte o processo de mobilização citado.

É reconhecido que os microrganismos contribuem para a solubilização de sulfetos metálicos desde os tempos antigos, tendo os romanos se beneficiado deles por um longo período antes de Cristo. Uma mina de cobre do Rio Tinto na Espanha foi, provavelmente, a primeira operação em larga escala onde os microrganismos desempenharam a principal função (BRIERLEY, 1978; BRIERLEY, 1982 apud ACEVEDO, 2002). 
O papel que os microrganismos desempenharam nesse processo foi demonstrado somente em 1947, quando COLMER e HINKLE isolaram as bactérias do gênero Acidithiobacillus sp. das águas ácidas das minas (LE ROUX, 1970 apud ACEVEDO, 2002). Mais tarde, Acidithiobacillus ferrooxidans (TEMPLE e COLMER, 1951 apud ACEVEDO, 2002) e Acidithiobacillus thiooxidans (TEMPLE e DELCHAMPS, 1953 apud ACEVEDO, 2002) foram isoladas e caracterizadas.

Estudo realizado por OHMURA et al. (2002) comprovou a evidência da utilização de quatro diferentes formas de respiração pela Acidithiobacillus ferrooxidans, incluindo $\mathrm{H}_{2} / \mathrm{Fe}^{3+}, \mathrm{H}_{2} / \mathrm{S}^{0}$ e $\mathrm{S}^{0} / \mathrm{Fe}^{3+}$ para o crescimento anaeróbio e $\mathrm{H}_{2} / \mathrm{O}_{2}$ para o crescimento aeróbio, sendo o $\mathrm{Fe}^{3+}, \mathrm{S}^{0}$ e $\mathrm{O}_{2}$ aceptores e o $\mathrm{H}_{2}$ e $\mathrm{S}^{0}$ doadores de elétrons.

A habilidade dos microrganismos lixiviarem e mobilizarem metais de materiais sólidos compreendem três princípios (KREBS et al., 1997):

1) Reações de óxido-redução;

2) Formação de ácidos orgânicos e inorgânicos;

3) Excreção de agentes complexantes.

As reações de óxido-redução são baseadas na transferência de elétrons dos minerais para os microrganismos, no caso de contato físico entre organismos e sólidos ou na oxidação bacteriana do $\mathrm{Fe}^{2+}$ para $\mathrm{Fe}^{3+}$, onde o íon férrico catalisa a solubilização dos metais como um agente oxidante (TORMA, 1991 apud KREBS et al., 1997).

Além de Acidithiobacillus ferrooxidans e A. thiooxidans, várias outras espécies de bactérias podem ser empregadas na biolixiviação de metais pesados: Acidithiobacillus concretivorus, Pseudomonas fluorescens, P. putida, Achromobacter, Bacillus licheniformis, B. cereus, B. luteus, B. polymyxa, B. megaterium, inclusive as termofílicas: Acidithiobacillus thermophilica, Thermothrix thioparus TH1 e Sulfobolus acidocaldarius (TAKAMATSU, 1995).

Conforme BERGEY (1994) apud TAKAMATSU (1995), as bactérias do gênero Acidithiobacillus sp. são gram-negativas, em forma de bastonete $(0,5 \times 1,0-4,0 \mu \mathrm{m})$, com algumas espécies móveis por meio de flagelos. Não possuem formas de resistência conhecidas. Obtém energia da oxidação de um ou mais compostos de enxofre reduzidos, incluindo sulfetos, enxofre, tiossulfato, politionatos e tiocianato. O sulfato é o produto final da oxidação dos compostos sulfurados, embora o enxofre, sulfitos ou politionatos possam ser acumulados. Algumas espécies também podem 
obter energia a partir da oxidação do íon ferroso. Todas as espécies são capazes de crescimento autótrofo. Algumas espécies são quimiolitotróficas obrigatórias, enquanto que outras são capazes de crescer quimiorganotroficamente. $O$ gênero inclui aeróbios obrigatórios e desnitrificantes facultativos. As espécies deste gênero exibem pH ótimo de crescimento na faixa de 2 a 8 e temperatura de 20 a $43^{\circ} \mathrm{C}$.

Devido à grande heterogeneidade fisiológica e genética dos microrganismos deste gênero, constatada pela relação mol\% $\mathrm{G}+\mathrm{C}$ do $\mathrm{DNA}$, diversidade de homologia do DNA, variedades de ubiquinona, conteúdo de ácidos graxos e a existência de espécies quimiolitotróficas e quimiorganotróficas, a validade taxonômica deste gênero pode ser discutida. O único fato que reúne estes microrganismos é que todos são eubactérias, em formato de bastonete e que obtêm energia para o seu crescimento autótrofo da oxidação do enxofre inorgânico.

A espécie Acidithiobacillus ferrooxidans, segundo TEMPLE e COLMER (1951), BERGEY (1994) apud TAKAMATSU (1995), consiste de bastonetes, geralmente únicos ou aos pares, 0,5 x 1,00 $\mu \mathrm{m}$, móveis. A linhagem-tipo é móvel por um único flagelo polar. Constituem pequenas colônias (0,5 a $1 \mathrm{~mm})$, crescidas em Agar tiosulfato ou tetrationato. O meio líquido com sulfato ferroso a pH 1,6 muda de uma coloração esverdeada para âmbar a marron-avermelhada, devido ao sulfato férrico. Em pH acima ou igual a 1,9, ocorre precipitação e incrustração considerável com sulfatos férricos básicos (jarositas). São quimiolitotróficas e autótrofas obrigatórias. Oxidam e se desenvolvem em $\mathrm{Fe}^{2+}$, pirita, vários minerais de sulfetos, enxofre, tiosulfato ou tetrationato. As condições ideais para crescimento são:

- temperatura: 30 a $35^{\circ} \mathrm{C}$;

- $\mathrm{pH}: 1,3$ a 4,5 .

$\mathrm{Na}$ figura a seguir, é apresentada uma imagem ampliada 30.000 vezes da bactéria Acidithiobacillus ferrooxidans, obtida com a utilização de microscópio eletrônico. 


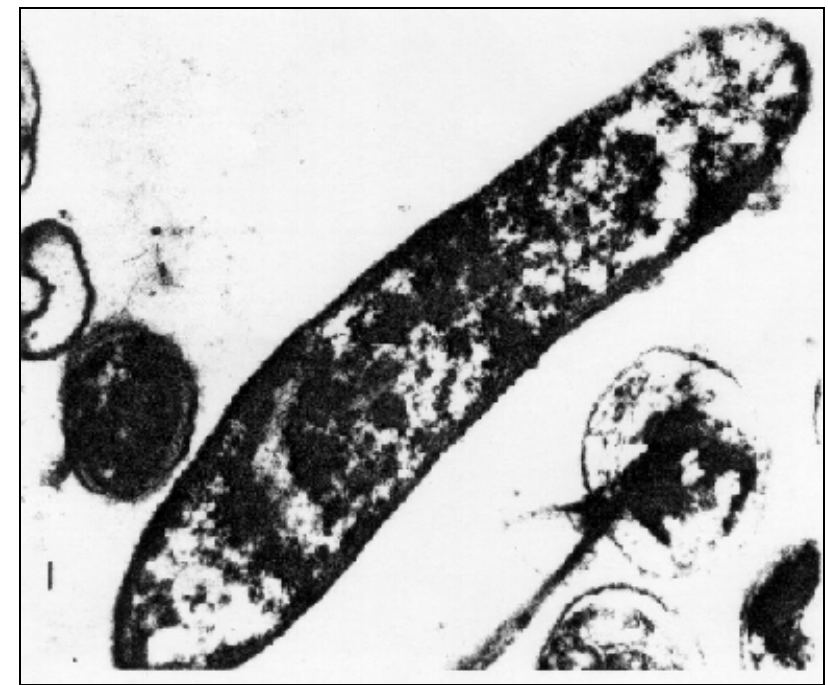

Figura 3.5.1. Acidithiobacillus ferrooxidans (imagem ampliada 30.000 vezes) ${ }^{3}$

A lixiviação microbiológica dos metais pesados pode ocorrer por vias diretas e indiretas, como descrito nas reações a seguir (RULKENS, GROTENHUIS e TICHÝ, 1995):

$$
\begin{gathered}
\mathrm{MS}+2 \mathrm{O}_{2} \rightarrow \mathrm{MSO}_{4}(1) \\
2 \mathrm{Fe}^{2+}+1 / 2 \mathrm{O}_{2}+2 \mathrm{H}^{+} \rightarrow 2 \mathrm{Fe}^{3+}+\mathrm{H}_{2} \mathrm{O}(2) \\
\mathrm{MS}+2 \mathrm{Fe}^{3+} \rightarrow \mathrm{M}^{2+}+2 \mathrm{Fe}^{2+}+\mathrm{S}^{0}(3) \\
\mathrm{S}^{0}+3 / 2 \mathrm{O}_{2}+\mathrm{H}_{2} \mathrm{O} \rightarrow 2 \mathrm{H}^{+}+\mathrm{SO}_{4}^{2-}(4) \\
\mathrm{H}_{2} \mathrm{SO}_{4}+\mathrm{M}^{2+} \rightarrow \mathrm{M}^{2+}-2 \mathrm{H}^{+}+\mathrm{MSO}_{4}(5)
\end{gathered}
$$

Na lixiviação direta, os compostos reduzidos de metais pesados (sulfetos metálicos) são diretamente oxidados, produzindo a solubilização dos metais pesados - reação (1).

$\mathrm{Na}$ via indireta, o íon ferroso é oxidado a íon férrico pela ação das bactérias Acidithiobacillus sp. - reação (2). O Fe ${ }^{3+}$ em contato com o sulfeto metálico produz a dissociação entre o cátion metálico e o enxofre elementar - reação (3). Em ambiente aeróbio, ocorre a formação do ácido sulfúrico, pela oxidação do enxofre elementar reação (4). O contato do ácido sulfúrico com o cátion metálico produz o composto solúvel sulfato metálico - reação (5).

\footnotetext{
${ }^{3}$ http://www.mines.edu/fs home/jhoran/ch126/thiobaci.htm
} 
O desempenho do processo de biolixiviação depende fortemente do estado de oxidação dos metais pesados presentes no solo a ser remediado. Os metais pesados, presentes nos sedimentos em condições anóxicas, são encontrados predominantemente como sulfetos ou outras formas reduzidas. Dessa forma, com a aplicação da técnica de biolixiviação, os sulfetos serão atacados diretamente, e outros compostos reduzidos de metais pesados serão rapidamente oxidados e conseqüentemente solubilizados. Sendo o valor do $\mathrm{pH}$ suficientemente baixo, os metais pesados liberados não ficarão significativamente adsorvidos no sedimento e ocorrerá a eficiente extração dos contaminantes.

A situação é diferente para materiais expostos a condições aeróbias. A presença de compostos oxidados de metais pesados favorece a ocorrência de transformações químicas, adsorção e outros efeitos relacionados à forte adesão dos metais pesados às partículas do solo. Dessa forma, o baixo valor do $\mathrm{pH}$ ou longos períodos de extração são necessários para a obtenção de uma eficiente remediação.

A solução ácida contendo sulfatos de metais pesados pode ser tratada em reatores anaeróbios, produzindo a redução a sulfeto. Os sulfatos são utilizados por determinados microrganismos anaeróbios como aceptores de elétrons. Essa reação produz sulfetos altamente reativos, que imediatamente reagem com os metais pesados em suspensão. Com a baixa solubilidade dos sulfetos metálicos, os contaminantes podem ser facilmente separados por sedimentação. O lodo metálico pode ser posteriormente tratado. Com o retorno do enxofre ao sistema (os sulfatos podem ser re-introduzidos à etapa de redução desses compostos), a concentração dos sulfetos no sistema pode superar a formação estequiométrica dos sulfetos metálicos (RULKENS, GROTENHUIS e TICHÝ, 1995). Dessa forma, os sulfetos podem ser subseqüentemente tratados pela etapa da oxidação parcial. Esse processo é governado por um grupo específico de Thiobacilli sp. não acidófilas, que podem formar o elemento enxofre no meio aquoso. Esse enxofre (enxofre biológico) é menos hidrofóbico, e pode ser facilmente encontrado em suspensão. Conseqüentemente, este enxofre é rapidamente oxidado pelas bactérias Thiobacilli $s p$. acidófilas, fechando o ciclo microbiano do enxofre (RULKENS, GROTENHUIS e TICHÝ, 1995). Na figura a seguir, é mostrado o ciclo microbiano do enxofre. 


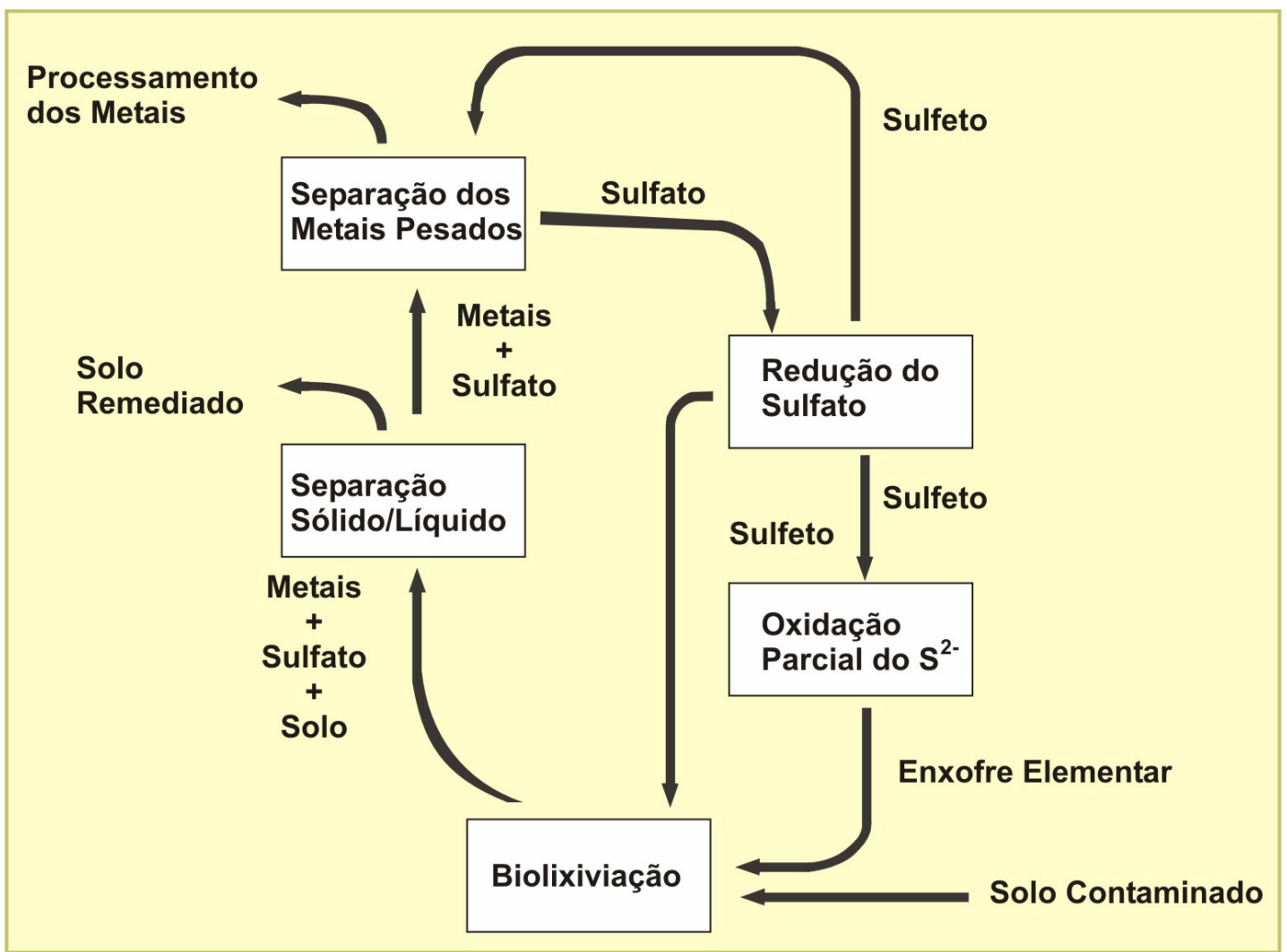

Figura 3.5.2. Ciclo microbiano do enxofre para remoção de metais pesados em solos e sedimentos (RULKENS, GROTENHUIS e TICHÝ, 1995).

O processo de biolixiviação pode ser acelerado através de duas vias: biorreatores e lixiviação ex situ (RULKENS, GROTENHUIS e TICHÝ, 1995).

Nos biorreatores, é necessária a apropriada mistura e aeração. O controle do processo envolve a adição de substrato (preferencialmente compostos de enxofre), bem como o controle do pH. Essa opção é mais favorável para a utilização em sedimentos anóxicos, desde que as bactérias Acidithiobacillus sp. podem aumentar significativamente a solubilização dos compostos metálicos reduzidos sem a diminuição do $\mathrm{pH}$ para abaixo de 2,0.

Na lixiviação ex situ, compostos de enxofre e microrganismos específicos misturados em água são introduzidos ou aspergidos em uma pilha formada por solo ou sedimento a ser remediado. A solução utilizada pode ser reaproveitada após regeneração, conforme mostrada na figura a seguir. 


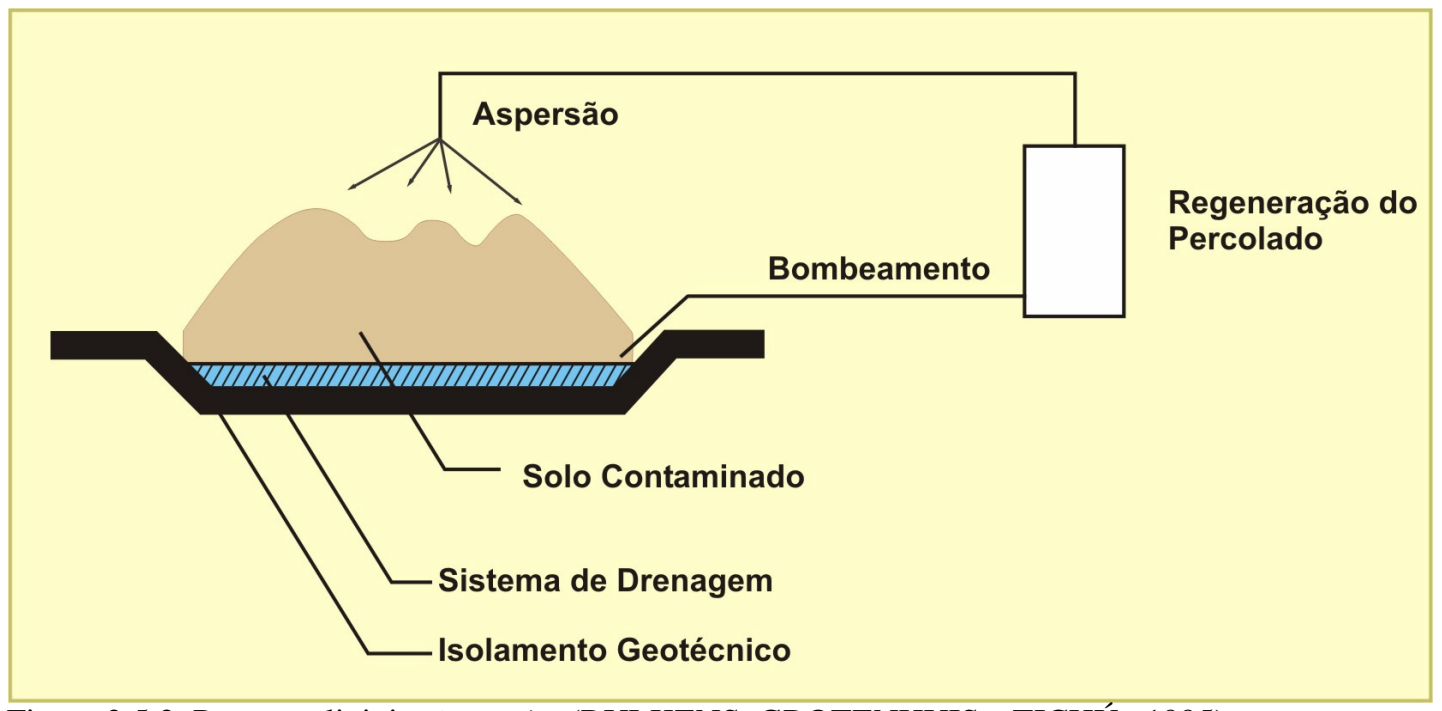

Figura 3.5.3. Processo lixiviação ex situ (RULKENS, GROTENHUIS e TICHÝ, 1995).

\subsubsection{Processos bioquímicos}

As reações de óxido-redução produzidas pela atividade microbiológica alteram o estado de oxidação dos metais pesados e produzem, dessa forma, a alteração das características de mobilidade desses elementos. A metilação ocorre pelo ataque dos grupos metil $\left(\mathrm{CH}_{3}\right)$ às formas inorgânicas dos íons metálicos, formando os compostos organometálicos. Estes são mais voláteis do que os metais inorgânicos, sendo esse processo passível de utilização para a remoção dos metais pesados do solo contaminado através da volatilização (GWRTAC, 1997).

\subsubsection{Físico-químicas}

As tecnologias físico-químicas disponíveis isolam (capeamento e barreiras subterrâneas), imobilizam (solidificação/estabilização e vitrificação) ou extraem (lixiviação ex situ, remediação eletrocinética e extração de vapores do solo) os contaminantes de uma determinada área.

\subsubsection{Isolamento físico}

As técnicas de isolamento são utilizadas para prevenir o transporte dos contaminantes através da contenção dessas substâncias no interior de uma determinada área.

Essas tecnologias podem ser utilizadas para prevenir a contaminação das águas subterrâneas quando não são disponíveis técnicas econômica e fisicamente viáveis para a remediação de uma área contaminada. As áreas contaminadas também podem 
ser isoladas temporariamente para limitar o transporte dos contaminantes durante os processos de gerenciamento e remediação.

As técnicas de isolamento da contaminação de uma determinada área incluem o capeamento e as barreiras subterrâneas (GWRTAC, 1997):

- Capeamento:

O sistema de capeamento é utilizado para prevenir a contaminação das águas superficiais e subterrâneas próximas à determinada área, através da instalação de uma barreira impermeável que impede a infiltração de águas superficiais no solo. Os objetivos secundários incluem o controle das emissões de gases liberados por contaminantes voláteis, melhoria estética da área e produção de uma superfície estável sobre a área contaminada.

A técnica de capeamento elimina riscos associados ao contato dérmico e/ou ingestão acidental da camada superficial do solo.

Vários materiais são utilizados na implantação do sistema de capeamento e a determinação da escolha depende das características do solo que será isolado. As membranas sintéticas como as de polietileno de alta densidade são alguns dos materiais utilizados nesse sistema. A revegetação é utilizada para reforçar a superfície da área isolada e reduzir a erosão através da diminuição da velocidade do escoamento superficial das águas pluviais e auxílio na remoção da água do solo pela evapotranspiração.

- Barreiras subterrâneas:

São utilizadas para o isolamento de solos e águas subterrâneas contaminadas através da restrição do seu fluxo em determinada área.

As barreiras verticais reduzem o fluxo lateral das águas subterrâneas na área isolada. Para um efetivo isolamento da matriz contaminada, a barreira deve ser formada por uma camada contínua de baixa permeabilidade, como as argilas e leitos de rocha, e instalada em todo o perímetro da área contaminada. Na indisponibilidade de um material impermeável, as águas subterrâneas devem ser extraídas para prevenir o transporte dos contaminantes sob a barreira. As barreiras verticais são freqüentemente instaladas em conjunto com o sistema de capeamento para prevenir a infiltração das águas superficiais no solo. 


\subsubsection{Imobilização química}

As tecnologias de imobilização são projetadas para reduzir a solubilidade dos contaminantes através da alteração das características físicas da matriz contaminada. As técnicas de imobilização são realizadas pelos processos de solidificação/estabilização e vitrificação (GWRTAC, 1997).

- Solidificação/estabilização:

O processo de solidificação produz uma matriz sólida que retém fisicamente o material contaminado.

A estabilização também retém os contaminantes, porém, através da utilização de agentes químicos que reduzem a solubilidade.

O processo de solidificação/estabilização ocorre pela injeção de agentes orgânicos (betumem) e inorgânicos (compostos alcalinos e fosfatados) no solo contaminado, com a formação de uma estrutura cristalina, vitrificada ou polimérica ao redor da área contaminada. $\mathrm{O}$ mecanismo dominante pelo qual os metais são imobilizados é a precipitação dos hidróxidos no interior da matriz sólida.

As tecnologias de solidificação/estabilização não são aplicáveis para o tratamento de áreas contaminadas por alguns tipos de metais, como por exemplo, as espécies existentes na forma de ânions (cromo hexavalente e arsênio) e para metais que formem hidróxidos pouco insolúveis (mercúrio).

Em comparação a outras técnicas de remediação, a imobilização química in situ é mais barata e produz resultados satisfatórios devido à formação de compostos metálicos de baixa solubilidade (BASTA e McGOWEN, 2003).

- Vitrificação:

A mobilidade dos metais pesados pode ser reduzida pelo tratamento da área contaminada através do aquecimento a elevadas temperaturas e formação de material vitrificado, geralmente um óxido sólido. Durante esse processo, pode ocorrer a volatilização ou destruição de contaminantes orgânicos ou espécies metálicas voláteis (mercúrio), que devem ser coletadas para o tratamento ou disposição.

O processo de vitrificação do solo contaminado pode ser realizado ex situ ou in situ. As etapas do processo de vitrificação ex situ incluem a escavação, pré-tratamento, homogeneização, aquecimento para a fusão/vitrificação e coleta dos gases extraídos do solo para tratamento. O processo in situ envolve a aplicação de corrente elétrica 
no solo com a utilização de rede de eletrodos posicionados verticalmente na área contaminada para a produção do aquecimento do solo e vitrificação do material contaminado após o resfriamento.

\subsubsection{Extração e/ou classificação (Lixiviação ex situ)}

Esse processo é utilizado para a remoção de metais pesados através da aplicação de uma suspensão química aquosa que produz a lixiviação dos contaminantes do solo escavado. As partículas finas $(<63 \mu \mathrm{m})$, freqüentemente, possuem a maior parte do material contaminado, devido à forte adesão dessas substâncias em sua elevada área superficial específica (GWRTAC, 1997).

A extração dos metais pesados do solo contaminado, através da utilização de um agente líquido, ocorre através de três processos: mistura intensa entre o solo contaminado e o agente de extração, separação do agente de extração e das partículas do solo e tratamento do agente de extração (RULKENS, GROTENHUIS e TICHÝ, 1995).

O primeiro mecanismo dissolve os contaminantes no agente de extração e pode ser otimizado pela adição de ácidos, surfactantes, agentes complexantes e hidróxido de sódio. O segundo mecanismo, ou seja, a separação do agente de extração e das partículas do solo não contaminado baseia-se no tamanho, velocidade de sedimentação, propriedades magnéticas e de superfície das partículas e o último processo é a recuperação do agente de extração, realizado em uma estação de tratamento de efluentes através de processos físico-químicos. A seguir, é apresentado o fluxograma do processo de tratamento de solo ex situ pela técnica de extração e/ou classificação. 


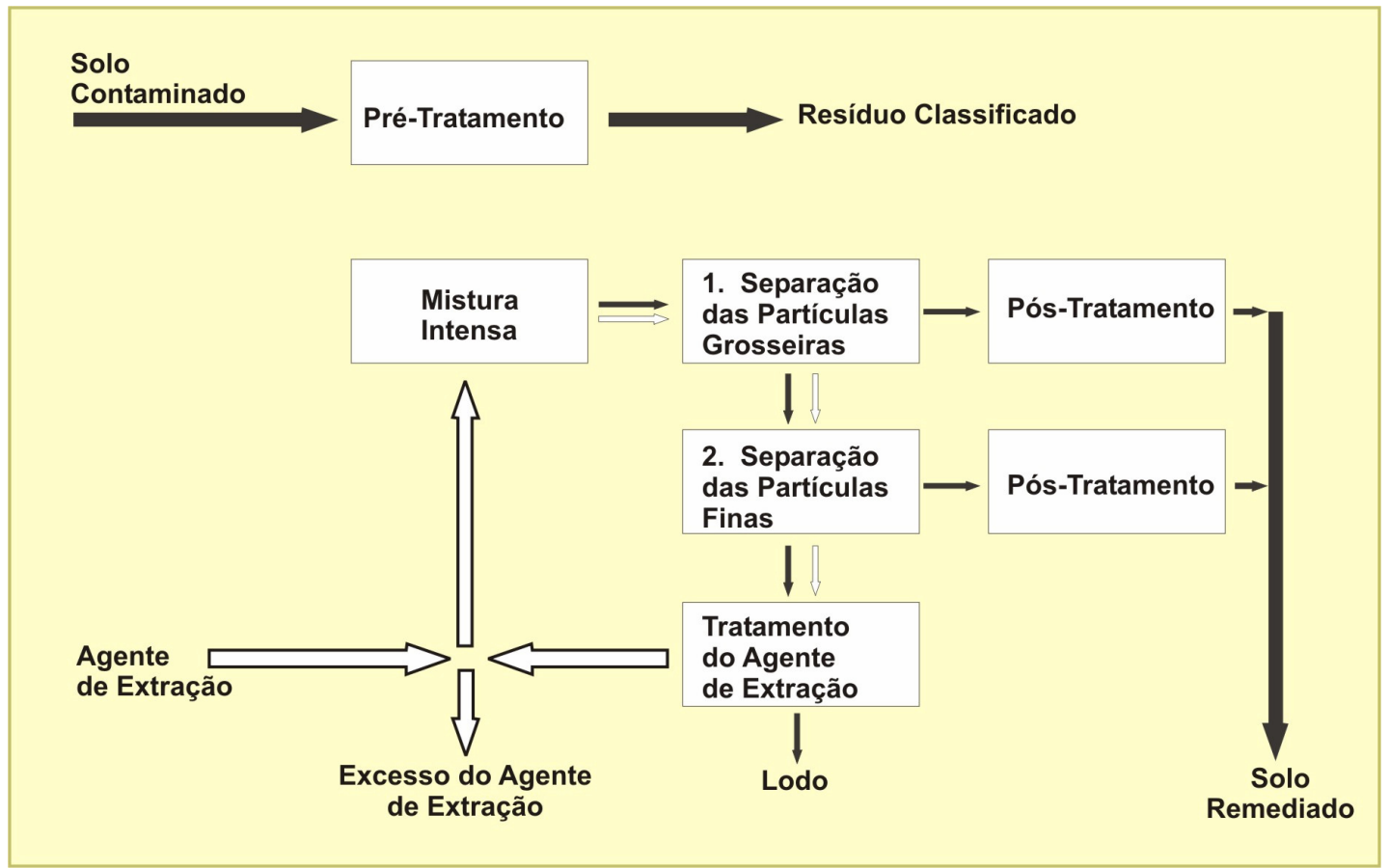

Figura 3.5.4. Fluxograma do processo de tratamento de extração/classificação do solo contaminado escavado (ex situ) (RULKENS, GROTENHUIS e TICHÝ, 1995).

Existem dois grupos de técnicas de extração baseadas na classificação de partículas ou na lixiviação, sendo que a maioria das instalações de remediação de solos utiliza a combinação dos dois métodos.

As técnicas utilizadas na classificação das partículas são (RULKENS, GROTENHUIS e TICHÝ, 1995):

- Hidrociclones: a separação das partículas ocorre através da força centrífuga. A separação seletiva é possível para partículas com diâmetro entre 10 a 20 m;

- Leito fluidizado: o sistema baseia-se na diferença entre a velocidade de sedimentação entre as pequenas partículas dos contaminantes e as partículas do solo não contaminado. Nesse sistema, a separação seletiva das partículas com diâmetro superior a $50 \mu \mathrm{m}$ é possível;

- Sistemas de separação gravimétrica: técnicas utilizadas na indústria minerária e que são aplicáveis à remediação de solos contaminados por metais pesados, como por exemplo, a utilização de mesas vibratórias;

- Flotação: através da adição de agentes químicos (coagulantes metálicos e polímeros) e de ar dissolvido ao material a ser tratado, ocorre o arraste das pequenas partículas dos contaminantes através da adsorção às microbolhas. Ao 
contrário dos outros processos de separação gravimétrica, a flotação possibilita a separação de partículas contaminadas e do solo de mesmo tamanho.

$\mathrm{Na}$ figura a seguir, são mostrados os desenhos esquemáticos do hidrociclone e do leito fluidizado.

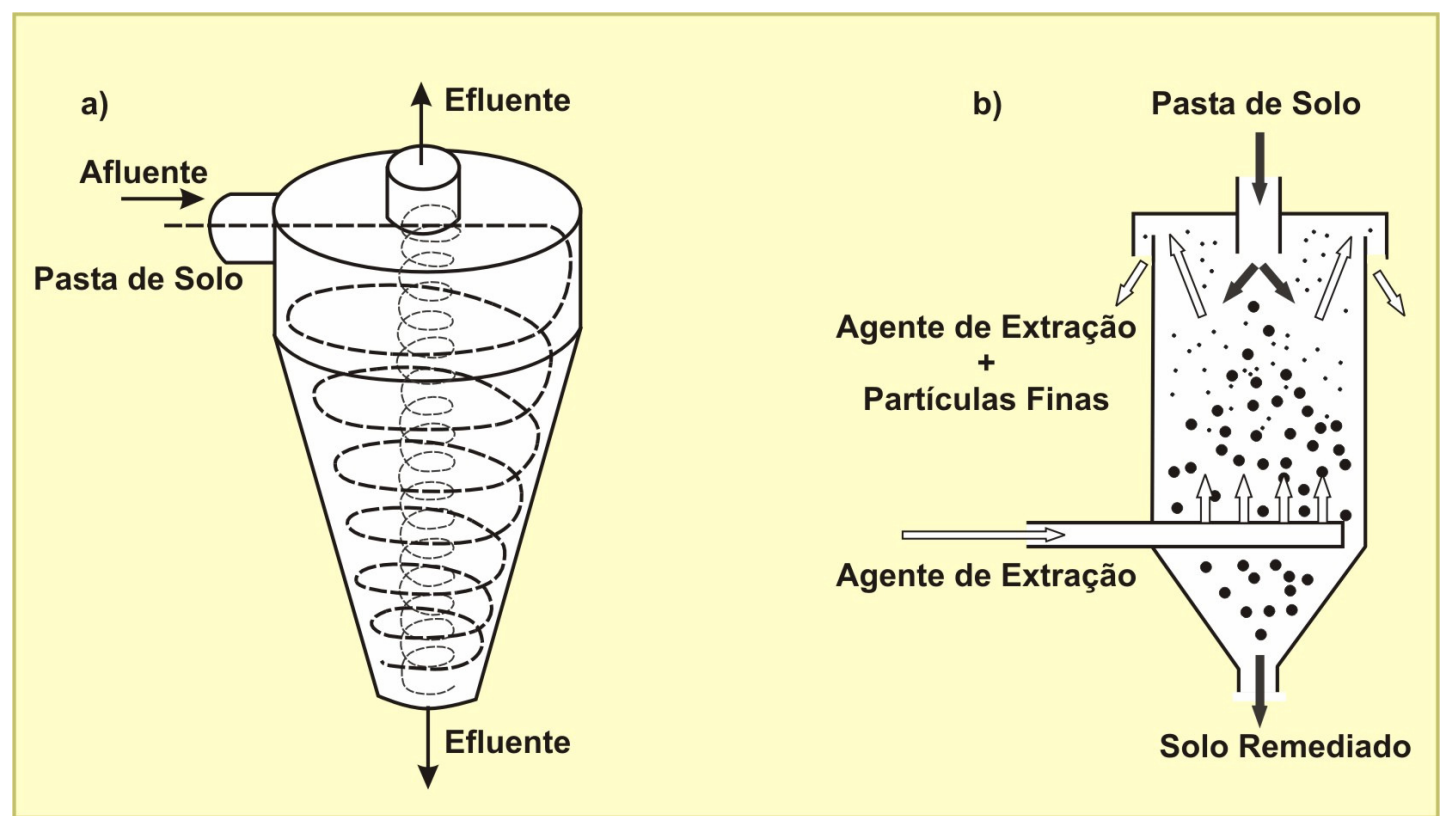

Figura 3.5.5. (a) Hidrociclone. (b) Leito fluidizado (RULKENS, GROTENHUIS e TICHÝ, 1995).

As técnicas utilizadas na lixiviação dos contaminantes são especialmente utilizadas para a remoção de metais pesados de solos e podem ser executadas com muitos tipos de agentes de extração, como:

- Ácidos inorgânicos: ácidos clorídrico e sulfúrico $(\mathrm{pH}<2,0)$;

- Ácidos orgânicos: ácido acético, lático e cítrico $(\mathrm{pH} \geq 4,0)$;

- Agentes complexantes: ácidos etilenodiaminatetracético (EDTA) e nitrilotriacético (NTA);

- Combinação entre ácidos orgânicos, agentes complexantes e ácidos inorgânicos (TUIN e TELS, 1991; EPA, 1991a apud RULKENS, GROTENHUIS e TICHÝ, 1995).

Na lixiviação com a utilização de ácidos, o pH baixo tem sido eficiente na remoção da maioria dos metais pesados em solos contaminados.

A extração com agentes complexantes não requer necessariamente baixo $\mathrm{pH}$, porém uma otimização substancial da extração de chumbo utilizando-se EDTA em baixo pH foi descrita por BROWN e ELLIOT em 1992 apud RULKENS, GROTENHUIS e TICHÝ (1995). No entanto, a desvantagem da utilização dos agentes complexantes 
é o elevado custo, porém a regeneração e reutilização desses compostos podem ser realizadas.

As técnicas de extração e classificação de solos contaminados escavados são amplamente aplicadas, principalmente em solos contendo quantidades inferiores a 10 e $20 \%$ de argila e substâncias húmicas.

\subsubsection{Eletrorremediação}

Técnica baseada em processos eletrocinéticos ocorridos quando uma corrente elétrica é gerada entre um cátodo e um ânodo posicionados em um terreno, proporcionando o transporte de íons e pequenas partículas carregadas eletricamente através da umidade e águas subterrâneas no solo. Três fenômenos de transporte são envolvidos (RULKENS, GROTENHUIS e TICHÝ, 1995):

- Eletrosmose: transporte do líquido intersticial contendo os contaminantes entre os eletrodos;

- Eletroforese: transporte das partículas carregadas eletricamente presentes no líquido intersticial, como os colóides e pequenas partículas de argila;

- Eletrólise: o transporte de íons e complexos iônicos presentes no líquido intersticial.

A remediação eletrocinética pode ser aplicada para a remoção de contaminantes iônicos ou partículas eletricamente carregadas presentes no solo. O método é especialmente aplicado para a remoção de metais pesados do solo. Com a remoção dos metais, a concentração dos íons do líquido intersticial diminui. Subseqüentemente, os metais adsorvidos às partículas do solo ou aderidos como óxidos, hidróxidos ou carbonatos são dissolvidos e dessa forma removidos do solo. A eletrorremediação é o único método in situ que pode ser utilizado para a remoção de metais pesados em solos argilosos contaminados (RULKENS, GROTENHUIS e TICHÝ, 1995).

Essa tecnologia também pode ser utilizada para o tratamento do solo escavado de uma área contaminada.

Na figura a seguir, ilustra-se um esquema do processo de remediação eletrocinética. 


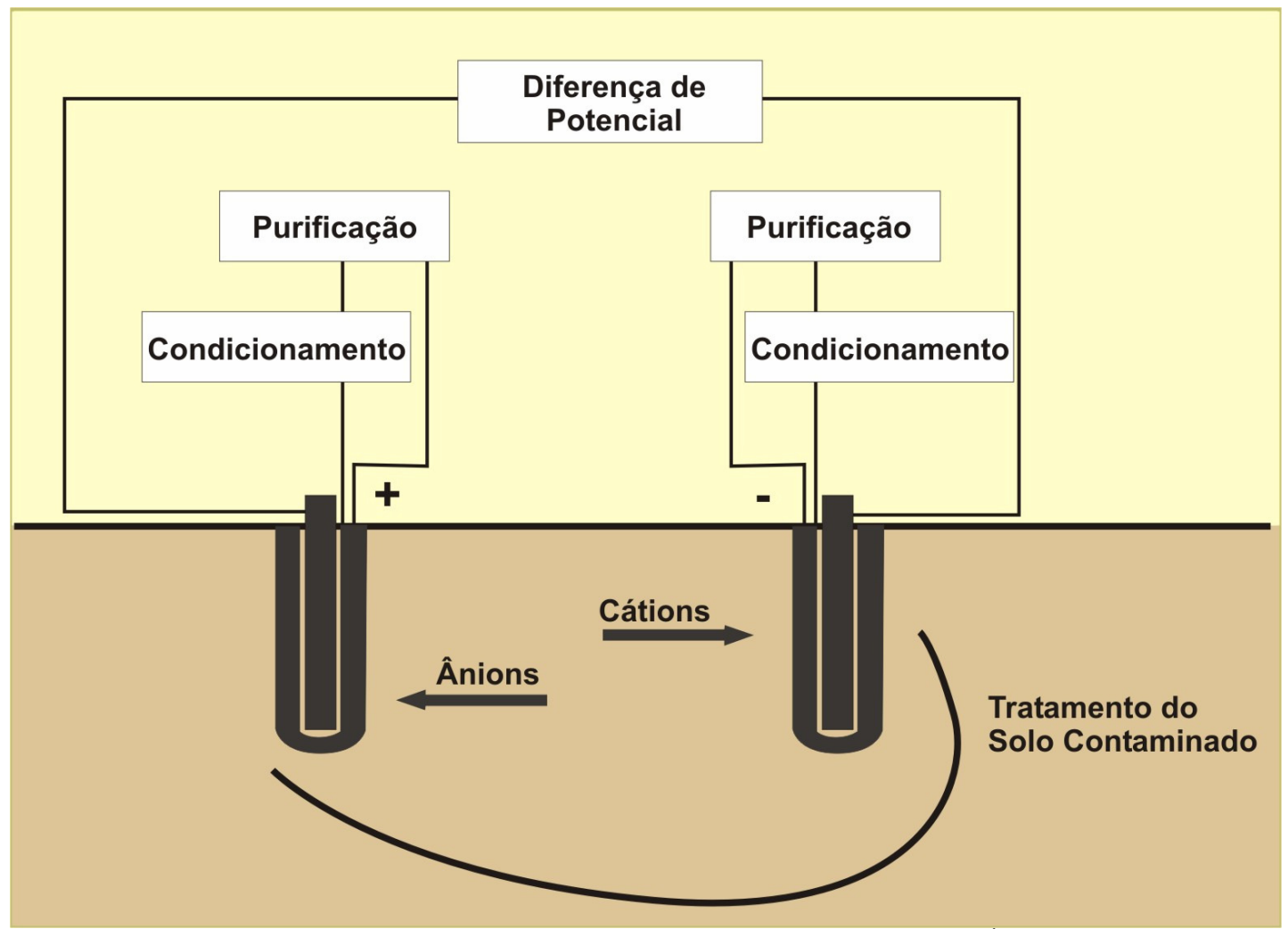

Figura 3.5.6. Remediação eletrocinética (RULKENS, GROTENHUIS e TICHÝ, 1995).

\subsubsection{Extração de vapores do solo}

Esse método é baseado na volatilidade dos contaminantes presentes no solo. A fase gasosa entre as partículas do solo em uma área contaminada está em equilíbrio com os contaminantes adsorvidos ou absorvidos por essas partículas. A quantidade de contaminantes na fase gasosa entre as partículas do solo é substancial para os de alta volatilidade. O fluxo produzido na área contaminada, através da extração da fase gasosa e injeção de ar, causa a completa remoção dos contaminantes voláteis da área contaminada (EPA, 1991b apud RULKENS, GROTENHUIS e TICHÝ, 1995).

O método da extração de vapores é aplicável para a remediação in situ de áreas contaminadas por compostos voláteis como o tricloroetileno, percloroetileno, tolueno, benzeno e um grande número de outros solventes orgânicos. Pode também ser utilizado para a remoção de compostos voláteis de mercúrio orgânico e arsênio. Essa técnica é recomendada somente para a remediação de solos com alta permeabilidade. A permeabilidade de solos argilosos é muito baixa para a realização de um processo de extração eficiente dos contaminantes (RULKENS, GROTENHUIS e TICHÝ, 1995). 
A injeção de ar no solo produz a eficiente transferência de oxigênio e conseqüente aumento da taxa de biodegradação. A utilização de um agente de extração líquido possibilita a remoção dos contaminantes não voláteis e não biodegradáveis. A figura a seguir apresenta o desenho esquemático do processo de extração de vapores do solo.

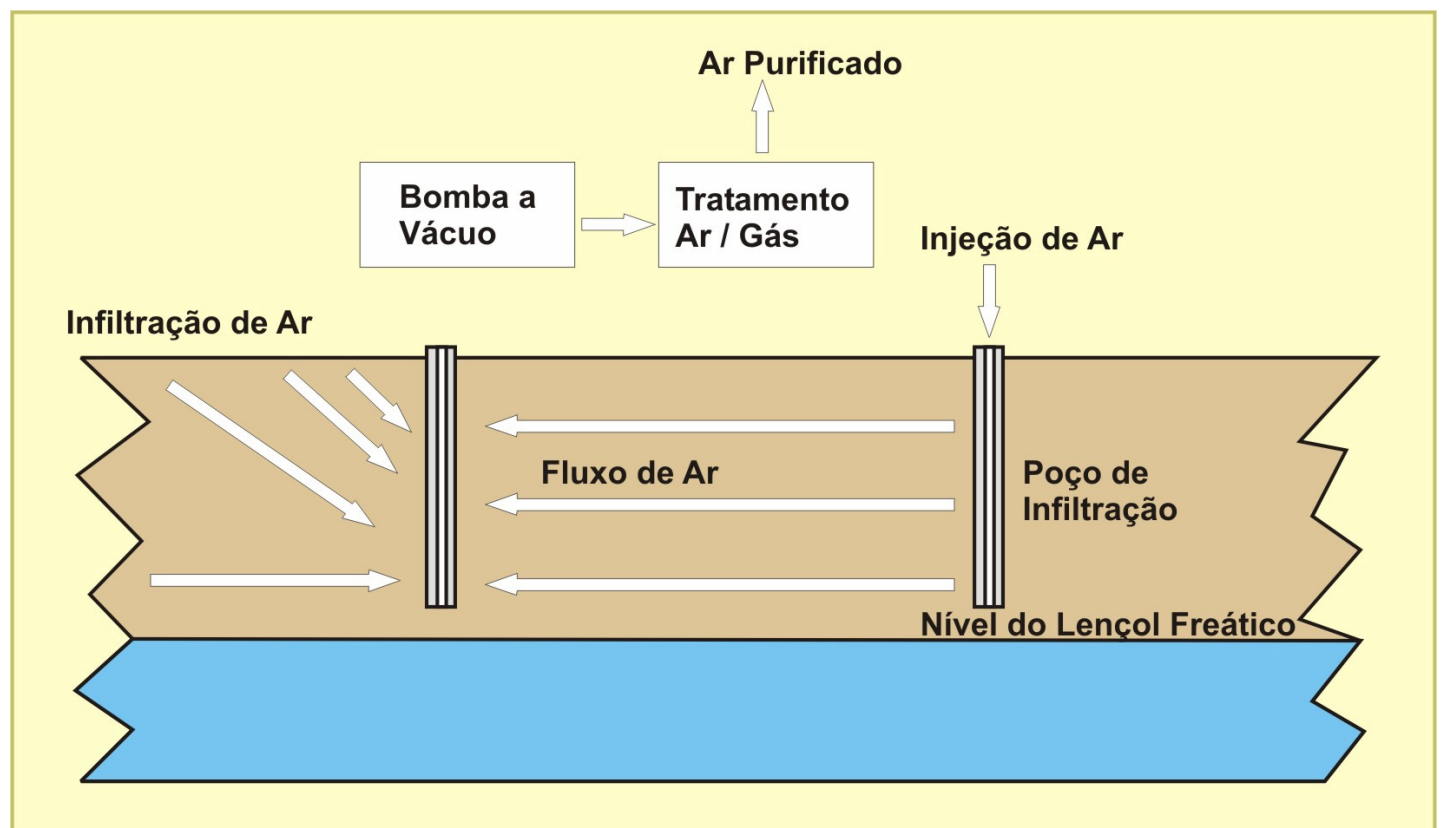

Figura 3.5.7. Extração de vapores do solo (RULKENS, GROTENHUIS e TICHÝ, 1995).

\subsubsection{Térmicas}

O tratamento térmico do solo escavado (ex situ) compreende a evaporação dos contaminates do solo a temperaturas entre 200 e $700^{\circ} \mathrm{C}$. Os compostos metálicos de mercúrio, arsênio e cádmio podem ser volatizados em temperaturas superiores a $800^{\circ} \mathrm{C}$ (RULKENS, GROTENHUIS e TICHÝ, 1995). A figura a seguir mostra o fluxograma do processo de tratamento térmico de solos contaminados. 


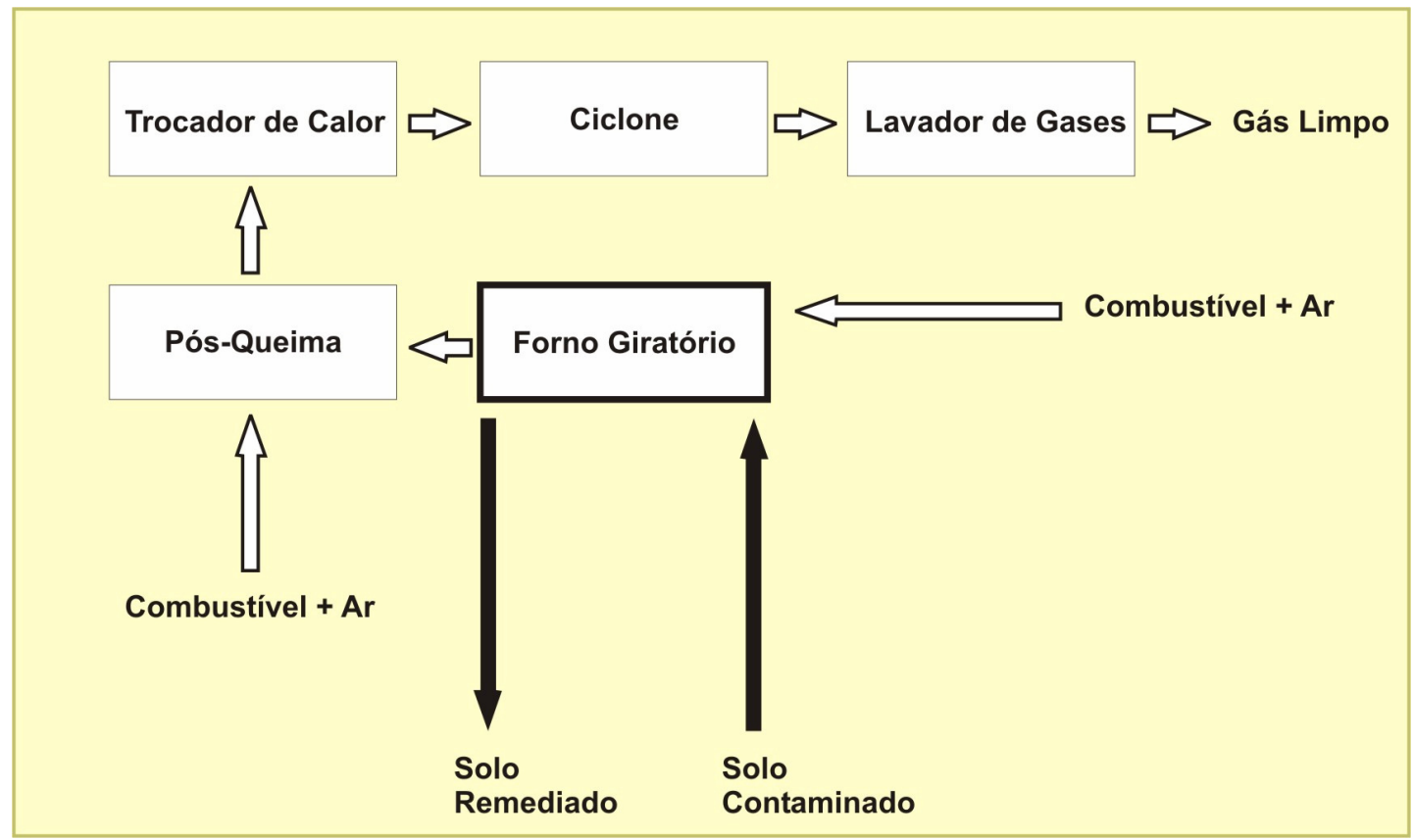

Figura 3.5.8. Fluxograma do processo de tratamento térmico de solos contaminados (RULKENS, GROTENHUIS e TICHÝ, 1995). 


\section{MATERIAL E MÉTODOS}

\section{1. Área de estudo}

O Pólo Cerâmico de Santa Gertrudes, localizado na região de Rio Claro, no Estado de São Paulo, é o maior do gênero no país, contando com mais de 40 unidades industriais do setor de pisos e revestimentos e responsável por mais da metade da produção nacional. O desenvolvimento desse segmento gera cerca de 5.000 empregos e apresentou em 1999, faturamento aproximado de R $\$ 500$ milhões, sendo a produção atual estimada em $12.000 .000 \mathrm{~m}^{2}$ de peças cerâmicas esmaltadas por mês (CETESB, 2004 apud MOURA, 2004).

Embora esse pólo tenha contribuído decisivamente para o crescimento econômico regional, também produziu efeitos deletérios para o meio ambiente, devido ao lançamento de efluentes líquidos e disposição inadequada de resíduos sólidos das linhas de esmaltação do processo produtivo das cerâmicas, contendo elevadas concentrações de $\mathrm{Pb}, \mathrm{Zn}$ e $\mathrm{B}$, assim como, $\mathrm{Cr}$, Ni, Ba, Cu, Zr, Ca, Na etc., nas cavas abandonadas, produzidas pela extração de argila, realizada há mais de 30 anos (MORITA et al., 2001). Essas cavas foram denominadas "lagos" e formados pela inundação produzida pelo afloramento do aquíffero da Formação Corumbataí.

A Região dos "Lagos de Santa Gertrudes" situa-se na porção mais a montante da bacia hidrográfica do Córrego da Fazenda Itaqui, inclusive suas nascentes e possui área aproximada de 144 ha. Esse curso d'água é sub-afluente do Rio Corumbataí, em uma das regiões mais degradadas ambientalmente do Estado de São Paulo (SALATI, 1997 apud GEO-INF, 2002). A bacia do Rio Corumbataí é um manancial que serve a sete municípios do interior paulista e beneficia uma população de mais de 650 mil habitantes (MORITA et al., 2001).

Os processos de lançamento de efluentes e o escoamento superficial de partículas carreadas nos períodos chuvosos proporcionaram, ao longo do tempo, uma contaminação significativa dos corpos d'água da região, acumulando-se em seus sedimentos, que hoje apresentam concentrações de metais pesados e boro várias vezes superiores ao substrato geológico natural (CETESB, 1997; HIDRO AMBIENTE, 2001 apud MORITA et al., 2001). 
Em estudos realizados por SILVA (2001), foi detectada a contaminação de solo, sedimentos, águas subterrâneas e superficiais por metais pesados $(\mathrm{Cd}, \mathrm{Pb}, \mathrm{Zn}$ etc.) e $\mathrm{B}$, associada a resíduos de indústrias cerâmicas da região. Trabalhos mais recentes indicaram, ainda, concentrações expressivas de Cd de até 4,21 mg/kg em sedimentos dos lagos (CETESB, 2002 apud GEO-INF, 2002).

Os resultados obtidos e descritos na tabela a seguir mostram os teores e concentrações detectados na área pesquisada por SILVA (2001), apresentada na figura 4.1.1.

Tabela 4.1.1 - Síntese das Análises de Pb, B, Zn, Cd e pH Efetuadas em Amostras de Solo, Sedimentos e Águas (superficiais e subterrâneas), coletadas na

Região dos Lagos de Santa Gertrudes (SILVA, 2001)

\begin{tabular}{|c|c|c|c|c|c|}
\hline Local & Parâmetro & Área I(*) & Área II(*) & Área III(*) & $\begin{array}{c}\text { Área de } \\
\text { Referência(*) }\end{array}$ \\
\hline \multirow{5}{*}{$\begin{array}{l}\text { Solos imaturos } \\
\text { (Sondagens a } \\
\text { trado) }\end{array}$} & $\mathrm{Pb}(\mathrm{mg} / \mathrm{kg})$ & 15 a 14.700 & 270 a 702 & 35 a 34.706 & 31 a 40 \\
\hline & $\mathrm{B}(\mathrm{mg} / \mathrm{kg})$ & 12 a 2.291 & 47 a 170 & 42 a 4.331 & 9,1 a 16,6 \\
\hline & $\mathrm{Zn}(\mathrm{mg} / \mathrm{kg})$ & 53 a 2.930 & 83 a 213 & 110 a 17.300 & 92 a 105 \\
\hline & $\mathrm{Cd}(\mathrm{mg} / \mathrm{kg})$ & $<0,5$ a 2,7 & $<0,5$ & $<0,5$ a 2,9 & $<0,5$ \\
\hline & $\mathrm{pH}$ & 4,9 a 8,3 & 6,0 a 7,8 & 5,3 a 8,2 & 6,6 a 7,3 \\
\hline \multirow{5}{*}{$\begin{array}{l}\text { Sedimento de } \\
\text { lagos (Piston- } \\
\text { core) }\end{array}$} & $\mathrm{Pb}(\mathrm{mg} / \mathrm{kg})$ & 38 a 4.178 & 10 a 1.570 & 48 a 234 & 32 a 49 \\
\hline & $\mathrm{B}(\mathrm{mg} / \mathrm{kg})$ & 21 a 3.760 & $<1$ a 197 & 97 a 478 & 30 a 49 \\
\hline & $\mathrm{Zn}(\mathrm{mg} / \mathrm{kg})$ & 63 a 4.195 & 38 a 365 & 47 a 145 & 43 a 68 \\
\hline & $\mathrm{Cd}(\mathrm{mg} / \mathrm{kg})$ & $<0,5$ a 3,8 & $<0,5$ a 1,2 & $<0,5$ a 1,5 & $<0,5$ a 1,1 \\
\hline & $\mathrm{pH}$ & 7,7 a 8,3 & 5,9 a 6,6 & 4,8 a 7,9 & 5,3 a 6,2 \\
\hline \multirow{5}{*}{$\begin{array}{c}\text { Águas } \\
\text { subterrâneas } \\
\text { (Poços de } \\
\text { monitoramento) }\end{array}$} & $\mathrm{Pb}(\mu \mathrm{g} / \mathrm{L})$ & 6 a 780 & $<1$ a 8 & 3 a 8 & 2 a 3 \\
\hline & $\mathrm{B}(\mathrm{mg} / \mathrm{L})$ & 1,4 a 504 & 3,5 a 21,9 & 2 a 10,5 & 1,5 a 2,5 \\
\hline & $\mathrm{Zn}(\mu \mathrm{g} / \mathrm{L})$ & 12 a 46 & 2,0 a 10,0 & 3 a 20 & 4 a 9 \\
\hline & $\mathrm{Cd}(\mu \mathrm{g} / \mathrm{L})$ & $<0,01$ a 1,01 & $<0,01$ a 0,58 & $<0,01$ a 0,03 & $<0,01$ \\
\hline & $\mathrm{pH}$ & 6,0 a 8,9 & 5,7 a 7,0 & 5,6 a 7,2 & 6 a 6,5 \\
\hline \multirow{5}{*}{$\begin{array}{c}\text { Águas } \\
\text { superficiais } \\
\text { (Lagos e } \\
\text { pequenos } \\
\text { cursos d'água) }\end{array}$} & $\mathrm{Pb}(\mu \mathrm{g} / \mathrm{L})$ & $<0,1$ a 30,1 & 0,5 a 13,5 & 25,5 a 30,1 & 0,3 \\
\hline & $\mathrm{B}(\mathrm{mg} / \mathrm{L})$ & 4,4 a 19,5 & 1,8 a 3,5 & 0,1 a 54,2 & 0,1 \\
\hline & $\mathrm{Zn}(\mu \mathrm{g} / \mathrm{L})$ & 0,9 a 45,0 & 4,9 a 51,6 & 7,2 a 17,7 & 15 \\
\hline & $\mathrm{Cd}(\mu \mathrm{g} / \mathrm{L})$ & $<0,01$ a 0,31 & $<0,01$ a 0,14 & $<0,01$ a 0,09 & $<0,01$ \\
\hline & $\mathrm{pH}$ & 6,0 a 7,8 & 6,8 a 7,8 & 5,6 a 7,6 & 6,9 \\
\hline
\end{tabular}

(*) Área I: Situa-se na porção oeste, mais à jusante da microbacia; Área II: Região central que engloba o pesqueiro e a antiga Indústria Poliglass; Área III: Região das nascentes do Córrego Fazenda Itaqui; Área de referência: amostra de solo coletada em local próximo à área de estudo e não impactado. 


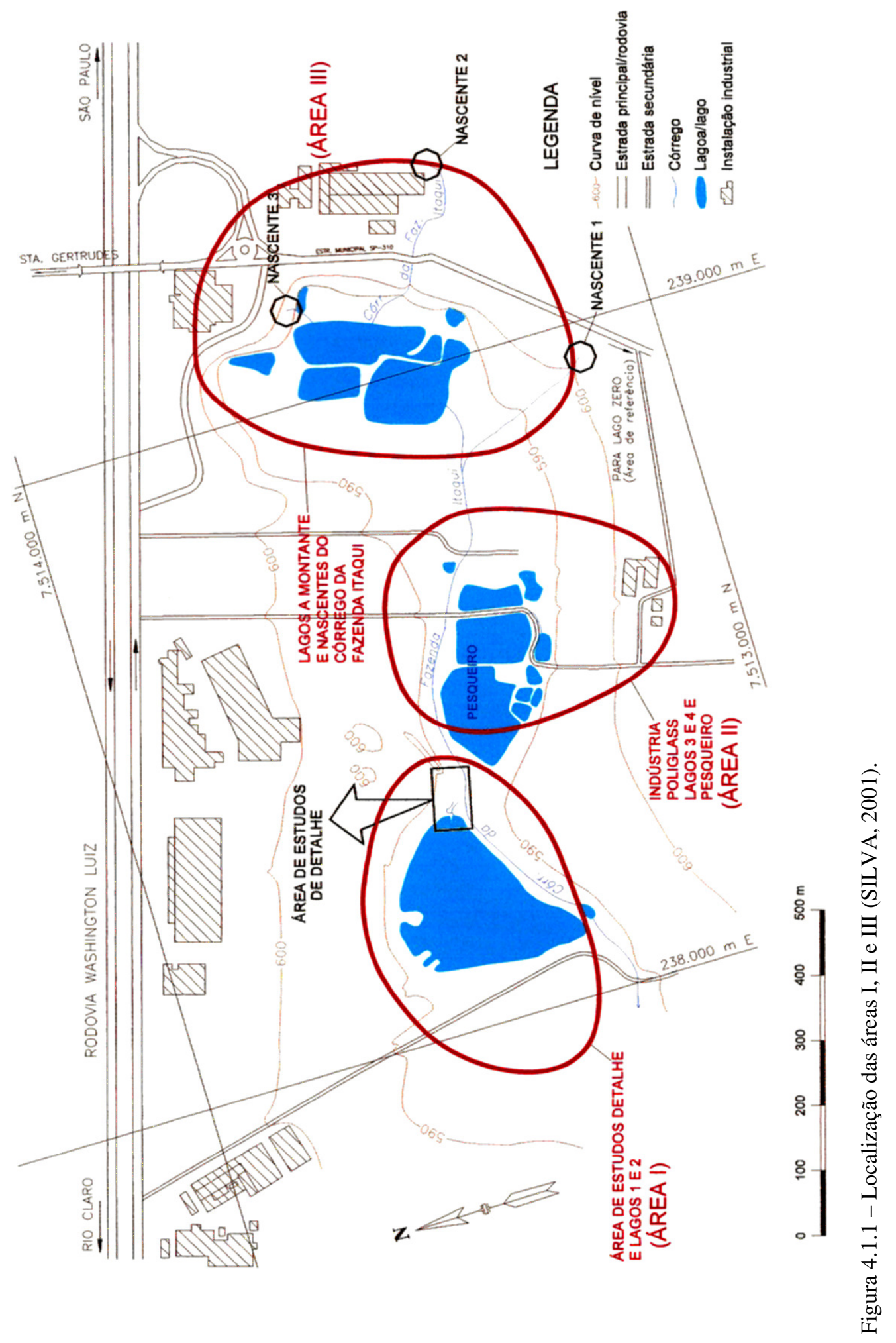




\subsection{Metodologia para realização da pesquisa}

\subsubsection{Coleta das amostras}

Foram realizadas duas coletas de solo pelo aluno André Negrão de Moura para realização da pesquisa de Doutorado mencionada no capítulo 1 , conforme os seguintes procedimentos (MOURA, 2004):

a) Coleta 1: utilizou-se trado manual, de $0,15 \mathrm{~m}$ de diâmetro, e procedeu-se a extração de amostras em um perfil de solo de um metro e meio de profundidade. Tendo em vista que o objetivo da avaliação preliminar foi utilizar o solo de um local que apresentasse a maior contaminação pelos metais de interesse, foram selecionados aleatoriamente três pontos na área de estudo (antiga empresa Polyglass), para a realização da coleta. As amostras foram acondicionadas em sacos plásticos e neles mantidas até a realização dos experimentos.

b) Coleta 2: face aos baixos teores dos elementos alvo da pesquisa, presentes no solo proveniente da coleta 1 , optou-se por executar uma nova coleta de material em outro ponto da área contaminada.

Utilizou-se pá e procedeu-se a coleta de solo proveniente da escavação e limpeza das nascentes existentes na área de estudo. Optou-se por utilizar este material visto que as nascentes em questão estão situadas na base do talude da área de estudo e como o transporte dos contaminantes alvo ocorreu pela ação do escoamento superficial no terreno, um maior teor destes encontrava-se na parte baixa em relação às cotas mais elevadas. Para garantir um suprimento de solo ao longo de toda a pesquisa, foi coletado aproximadamente $1 \mathrm{t}$ de material, que foi transportado e acondicionado em reservatório de polietileno até sua utilização.

As amostras do solo bruto e tratado e do lixiviado utilizadas/geradas durante os ensaios de lavagem com ácido clorídrico concentrado e solução de peróxido de hidrogênio a $30 \%$ seguiram a seguinte sistemática, quanto a sua coleta e preparo, antes de serem enviadas para análise:

a) Solo bruto: toda amostra de solo bruto utilizado nos experimentos foi destorroada e peneirada em peneira com malha de $2 \mathrm{~mm}$ para a remoção do material grosseiro. $\mathrm{O}$ material resultante foi homogeneizado e procedeu-se a coleta de amostras após o seu quarteamento. Das amostras coletadas, determinou-se a umidade, a fim de permitir a 
expressão dos resultados das análises químicas em relação ao solo seco a $103{ }^{\circ} \mathrm{C} \pm 2$ ${ }^{\circ} \mathrm{C}$ e, de determinar o teor de sólidos utilizado no experimento;

b) Solo tratado: o solo tratado (sob a forma de lama) foi coletado em diversas profundidades dos reatores através de pipetas de vidro. Em todas as coletas foi controlado o volume e a massa da amostra de lama, a qual recebeu o seguinte tratamento:

- Centrifugação por 15 minutos, a 4.000 rpm, em temperatura ambiente: o objetivo da centrifugação foi o de promover a separação das fases sólida e líquida da amostra;

- Fração líquida: após a centrifugação, procedeu-se a coleta do sobrenadante dos tubos de centrífuga e determinou-se seu volume e massa. A amostra líquida foi filtrada em membrana de $0,45 \mu \mathrm{m}$ de porosidade, recebeu $2 \% \mathrm{v} / \mathrm{v}$ de $\mathrm{HNO}_{3}$ concentrado para sua preservação e, foi mantida sob refrigeração a $4^{\circ} \mathrm{C}$ até ser analisada;

- Fração sólida: após a remoção do sobrenadante, a fração sólida foi removida dos tubos de centrífuga com espátula metálica e procedeu-se a determinação de sua massa úmida e seca. Na determinação da massa, utilizou-se cápsula de porcelana, que foi seca em estufa a $60{ }^{\circ} \mathrm{C}$ por 24 horas. Após a determinação da massa seca, a amostra foi triturada em almofariz e acondicionada em saco plástico, tipo zip lock, até o momento da análise.

A coleta da fase líquida (lixiviado) no ensaio realizado com a solução de ácido clorídrico $0,1 \mathrm{M}$ foi realizada com pipeta graduada de $5 \mathrm{~mL}$, posteriormente filtrada em membrana de $0,45 \mu \mathrm{m}$ de porosidade e mantida sob refrigeração a $4^{\circ} \mathrm{C}$ até a realização da análise química de determinação dos metais.

\subsubsection{Caracterização granulométrica e mineralógica}

A caracterização granulométrica da amostra de solo foi realizada no Laboratório de Solos do Departamento de Estruturas e Fundações da Escola Politécnica da USP, através do procedimento descrito na Norma Técnica 7.181 (BRASIL, 1984).

A caracterização mineralógica foi realizada no Laboratório de Caracterização Mineralógica do Departamento de Engenharia de Minas e Petróleo da Escola Politécnica da USP, através da utilização dos ensaios de difratometria (determinação 
da composição cristalina do solo) e fluorescência de raios-X (determinação dos teores de óxidos).

No ensaio de difratometria de raios-X (Método do Pó), a amostra de solo é quarteada para obtenção de uma fração de aproximadamente 20 g. Em seguida, é reduzida granulometricamente para aproximadamente mesh $200(74 \mu \mathrm{m})$, e uma alíquota entre 1 a 3 g é compactada em uma cavidade de $27 \mathrm{~mm}$ de diâmetro por 2,5 $\mathrm{mm}$ de profundidade de um suporte metálico. Posteriormente, é introduzida no difratômetro marca Philips, modelo MPD 1.880. A identificação das fases cristalinas é obtida por comparação do difratograma da amostra com o banco de dados do ICDD International Centre for Diffraction Data.

A metodologia do ensaio de fluorescência de raios- $X$ inclui as seguintes etapas: secagem e quarteamento das amostras para obtenção de uma fração de aproximadamente $50 \mathrm{~g}$; redução granulométrica da amostra para aproximadamente mesh $400(37 \mu \mathrm{m})$; compactação do pó em prensa de 20 t; introdução da amostra compactada no equipamento de fluorescência de raios-X.

\subsubsection{Determinação da concentração de carbono total, hidrogênio e nitrogênio}

A determinação desses parâmetros foi realizada pela Análise Elementar de CHN em equipamento Elemental Analyzer 2.400 CHN Perkin Elmer do Laboratório da Central Analítica do Instituto de Química da USP.

As etapas de identificação dos teores de carbono total, hidrogênio e nitrogênio são: pesagem de aproximadamente $2 \mathrm{mg}$ da amostra de solo; injeção no equipamento analisador onde ocorre a combustão a $925^{\circ} \mathrm{C}$ em presença de oxigênio puro; transformação do carbono total, hidrogênio e nitrogênio presentes em gás carbônico, água e vários óxidos de nitrogênio (reduzidos no tubo de redução para $\mathrm{N}_{2}$ ), respectivamente; arraste do $\mathrm{CO}_{2}, \mathrm{H}_{2} \mathrm{O}$ e $\mathrm{N}_{2}$ pelo gás hélio para a coluna de separação; encaminhamento para o detector de condutividade térmica (TCD); a leitura é realizada em $\mathrm{mV}$ e calculada em teor de carbono total, hidrogênio e nitrogênio.

\subsubsection{Determinação dos teores de metais pesados}

Os teores e concentrações dos metais $\mathrm{B}, \mathrm{Cd}, \mathrm{Pb}$ e $\mathrm{Zn}$ presentes no solo bruto e nas fases sólida e líquida da suspensão foram determinados pelo Laboratório da Central Analítica do Instituto de Química da USP, através da utilização de espectrometria de 
emissão atômica com plasma de argônio induzido - Método 6010B (USEPA, 1996b). As amostras foram previamente digeridas em solução ácida conforme descrito no Método 3050B (USEPA, 1996a).

\subsubsection{Lixiviação dos metais $\mathrm{B}, \mathrm{Cd}, \mathrm{Pb}$ e $\mathrm{Zn}$ do solo através da utilização dos} agentes oxidantes ácido sulfúrico concentrado, peróxido de hidrogênio a $30 \%$ e ácido clorídrico $0,1 \mathrm{M}$

Os ensaios de lixiviação dos metais $\mathrm{B}, \mathrm{Cd}, \mathrm{Pb}$ e $\mathrm{Zn}$ do solo com a utilização de ácido sulfúrico concentrado e peróxido de hidrogênio a $30 \%$ foram conduzidos no mesmo equipamento utilizado na pesquisa de Doutorado do aluno André Negrão de Moura, representado esquematicamente na figura a seguir.
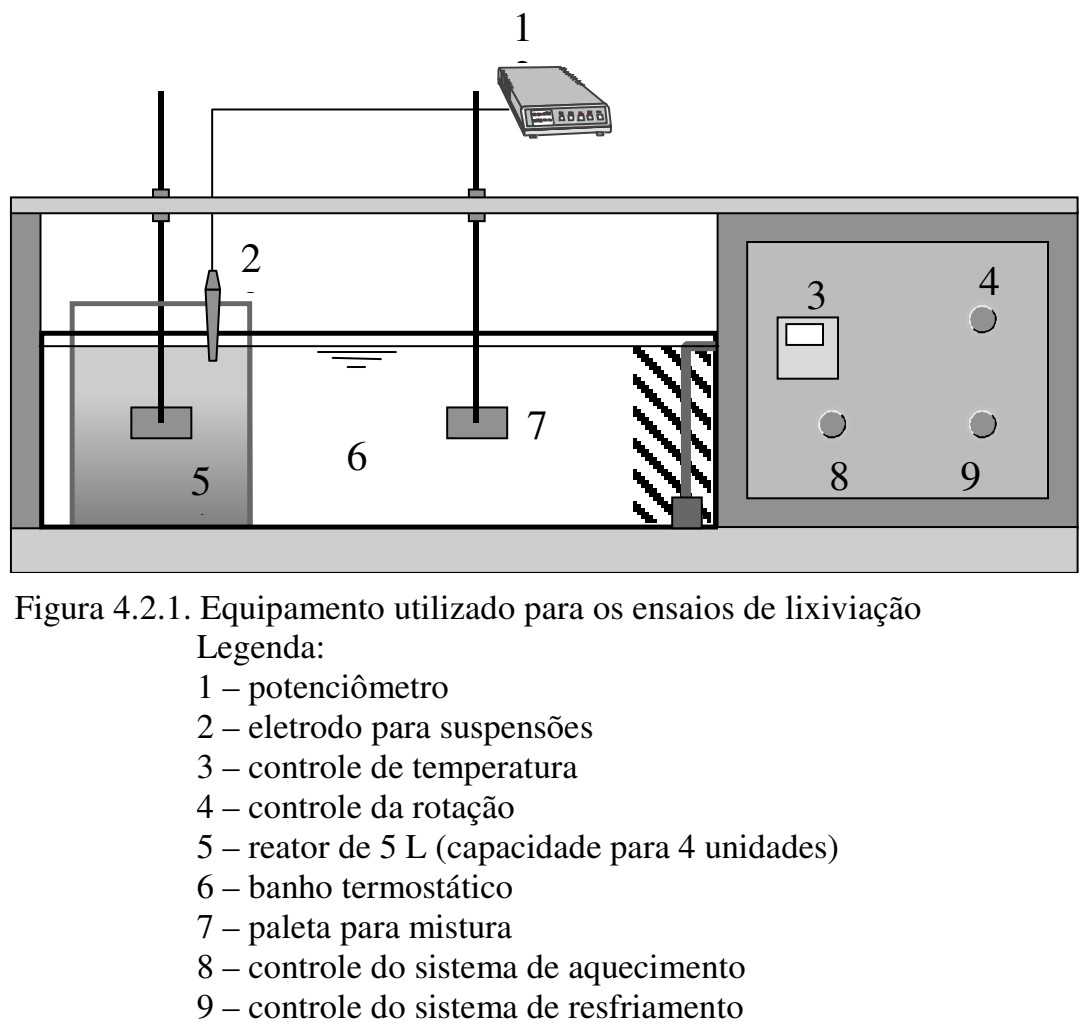

Foi preparada suspensão de solo com $25 \%$ de teor de sólidos, mantida sob agitação em 200 rpm e à temperatura ambiente. O teor de sólidos da suspensão foi determinado após a avaliação dos resultados dos ensaios de biolixiviação da referida pesquisa de Doutorado. Os ensaios foram realizados em triplicata. 
- Ensaio com ácido sulfúrico concentrado:

À suspensão de solo, foi adicionado o volume de ácido sulfúrico concentrado necessário à estabilização do pH entre 7 e 2, partindo-se de 8 . Após estabilização em cada valor de $\mathrm{pH}$, de cerca de 24 horas, amostras de $50 \mathrm{~mL}$ foram coletadas e centrifugadas a $4.000 \mathrm{rpm}$ durante 15 minutos, para separação das fases sólida e líquida. A fase líquida, contendo os metais lixiviados do solo, foi filtrada em membrana Millipore de teflon hidrofílico com porosidade de 0,45 $\mu \mathrm{m}$, para separação dos sólidos em suspensão, armazenada acidificada e sob refrigeração. A fase sólida foi seca em estufa a $60^{\circ} \mathrm{C}$ por 24 horas, cuidadosamente masserada e assim como a fase líquida, encaminhada para determinação química de metais no Laboratório da Central Analítica do Instituto de Química da USP.

- Ensaio com solução de peróxido de hidrogênio a 30\%:

A utilização da solução de peróxido de hidrogênio a $30 \%$ objetivou a oxidação dos compostos orgânicos presentes no solo e conseqüente dessorção dos metais $\mathrm{B}, \mathrm{Cd}$, $\mathrm{Pb}$ e $\mathrm{Zn}$ da matriz sólida.

Ao volume de 4 litros de suspensão de solo com teor de sólidos de $25 \%$ foi adicionado volume de peróxido de hidrogênio a 30\% para oxidação do carbono total detectado através da análise elementar de $\mathrm{CHN}$.

Após análise dos resultados de lixiviação dos metais, obtidos pelas dosagens da solução de peróxido de hidrogênio a 30\%, calculadas estequiometricamente para oxidação do carbono presente no solo bruto, conforme teores detectados nas análises químicas, optou-se por avaliar o comportamento do $\mathrm{Pb}$ e Zn após o tratamento da suspensão de solo com dosagens do agente oxidante superiores às inicialmente utilizadas.

Na tabela a seguir, são listadas as dosagens de peróxido de hidrogênio a 30\% obtidas estequiometricamente e aquelas utilizadas para comparação dos resultados inicialmente obtidos. 
Tabela 4.2.1 - Teores de Carbono do Solo Bruto e Dosagens de $\mathrm{H}_{2} \mathrm{O}_{2} 30 \%$

\begin{tabular}{c|c|c|c}
\hline Teor de C (\%) & $\begin{array}{c}\text { Dosagem de } \\
\mathbf{H}_{\mathbf{2}} \mathbf{O}_{\mathbf{2}} \mathbf{3 0 \%}(\boldsymbol{\%})\end{array}$ & $\begin{array}{c}\text { Volume de } \mathrm{H}_{\mathbf{2}} \mathbf{O}_{\mathbf{2}} \mathbf{3 0} \% \\
\text { Dosado }(\mathbf{m L})\end{array}$ & $\begin{array}{c}\text { Massa de } \mathrm{H}_{\mathbf{2}} \mathbf{O}_{\mathbf{2}} \mathbf{3 0 \%} \\
\text { por Massa de Solo }(\mathbf{g} / \mathbf{k g})^{(\mathbf{4})}\end{array}$ \\
\hline 0,40 & $4,53^{(1)}$ & 116,94 & 151,11 \\
\hline 0,61 & $6,91^{(1)}$ & 178,33 & 230,44 \\
\hline 0,80 & $9,07^{(1)}$ & 233,88 & 302,22 \\
\hline 1,76 & $20,00^{(2)}$ & $385,90^{(3)}$ & 664,88 \\
\hline 3,53 & $40,00^{(2)}$ & $774,00^{(3)}$ & $1.333,55$ \\
\hline 4,41 & $50,00^{(2)}$ & $966,96^{(3)}$ & $1.666,09$ \\
\hline
\end{tabular}

Obs: (1) obtida estequiometricamente;

(2) utilizada para confirmação dos resultados preliminares;

(3) volume da suspensão $=3 \mathrm{~L}$;

(4) massa de $\mathrm{H}_{2} \mathrm{O}_{2} 30 \%$ por massa de solo (g/kg): $\left\{\left[\left(\right.\right.\right.$ volume de $\mathrm{H}_{2} \mathrm{O}_{2} 30 \%$ dosado (L) $x$ densidade da solução de $\left.\mathrm{H}_{2} \mathrm{O}_{2} 30 \%(1,11 \mathrm{~kg} / \mathrm{L})\right]$ / massa de solo $\left.(\mathrm{kg})\right\}$ x 100 .

Após a dosagem do agente oxidante, a suspensão foi mantida sob agitação durante 3 horas. As amostras foram manipuladas e acondicionadas da mesma forma como no ensaio com o ácido sulfúrico.

- Ensaio com ácido clorídrico 0,1 M:

O procedimento do ensaio com a solução de ácido clorídrico 0,1 M seguiu a etapa de abertura leve da extração seqüencial de metais pesados proposto por KERSTEN e FÖRSTNER (1990) e BEVILACQUA e LICHTIG (2004).

No método de extração leve, quantidade superior a 1,2500 g de amostra de solo é seca à temperatura de $60^{\circ} \mathrm{C}$ por um período de 96 horas e na seqüência transfere-se uma massa exata de 1,2500 g a um erlenmeyer de $250 \mathrm{~mL}$. Adiciona-se $25 \mathrm{~mL}$ de $\mathrm{HCl}$ 0,1 M e agita-se essa suspensão em rotação de $200 \mathrm{rpm}$ por período de 2 horas. A suspensão é mantida em repouso e em seguida filtrada em membrana Millipore de teflon hidrofílico com porosidade de $0,45 \mu \mathrm{m}$, para separação dos sólidos em suspensão. $\mathrm{O}$ filtrado é mantido a $4^{\circ} \mathrm{C}$ até a determinação das concentrações dos metais. 


\section{RESULTADOS E DISCUSSÃO}

\subsection{Caracterização granulométrica e mineralógica do material contaminado}

A caracterização granulométrica do material contaminado, previamente destorroada e passada em peneira $\mathrm{n}^{\mathrm{o}} 10(2 \mathrm{~mm})$ para remoção do material grosseiro, realizada pelo Laboratório de Solos do Departamento de Estruturas e Fundações da Escola Politécnica, identificou a predominante presença de argila, conforme apresentada na tabela a seguir. A massa específica foi determinada em $2,7 \mathrm{~g} / \mathrm{cm}^{3}$.

Tabela 5.1.1 - Distribuição Granulométrica da Amostra do Solo Bruto

\begin{tabular}{c|c|c}
\hline Fração & Diâmetro das partículas $(\mathbf{m m})$ & Distribuição $(\%)$ \\
\hline Argila & $<0,002$ & 53 \\
Silte & $>0,002$ até 0,05 & 31 \\
Areia fina & $>0,05$ até 0,40 & 15 \\
\hline Areia média & $>0,40$ até 2,00 & 1 \\
\hline
\end{tabular}

O resultado do ensaio de caracterização mineralógica, realizado pelo Laboratório de Caracterização Tecnológica do Departamento de Engenharia de Minas e Petróleo da Escola Politécnica da USP, é apresentado na tabela a seguir.

Tabela 5.1.2 - Fases Cristalinas do Material Contaminado da Região dos Lagos de Santa Gertrudes

\begin{tabular}{c|c|c|c}
\hline ICDD $(*)$ & Nome do composto & Fórmula química & Mineral \\
\hline $01-086-1629$ & Quartzo & $\mathrm{SiO}_{2}$ & Quartzo \\
\hline $01-086-1385$ & Muscovita & $\mathrm{K}_{0,86} \mathrm{Al}_{1,94}\left(\mathrm{Al}_{0,965} \mathrm{Si}_{2,895} \mathrm{O}_{10}\left((\mathrm{OH})_{1,744} \mathrm{~F}_{0,256}\right)\right.$ & Muscovita \\
\hline $01-089-8104$ & Hematita & $\mathrm{Fe}_{2} \mathrm{O}_{3}$ & Hematita \\
\hline $00-008-0048$ & Ortoclásio & $\mathrm{K}\left(\mathrm{Al}, \mathrm{Fe}_{2}\right) \mathrm{Si}_{2} \mathrm{O}_{8}$ & Ortoclásio \\
\hline $01-071-1167$ & Anatásio & $\mathrm{TiO}_{2}$ & Anatásio \\
\hline $00-029-1488$ & Caulinita & $\mathrm{Al}_{2} \mathrm{Si}_{2} \mathrm{O}_{5}(\mathrm{OH})_{4}$ & Caulinita \\
\hline
\end{tabular}

(*) ICDD: International Centre for Diffraction Data

Conforme apresentado no estudo realizado por SILVA (2001), os solos no município de Santa Gertrudes foram identificados pelo Instituto Agronômico de Campinas, em 1999, como solos podzólicos e terras roxas estruturadas, ou seja, perfis naturais (horizontes B) de latossolos.

A presença de quartzo é muito freqüente nestes solos, quase sempre predominante nas frações areia e pedregulho (NOGAMI, 1995). Os grãos de quartzo, quando 
presentes na fração areia dos latossolos, produzem uma película de óxidos, responsável pela tonalidade avermelhada, arroxeada ou amarelada do conjunto.

O quartzo, a muscovita (mica) e o ortoclásio (feldspato), entre outros, são considerados minerais primários, ou seja, aqueles em que a estrutura e a composição química foram obtidas durante o processo de cristalização da lava vulcânica (EVANGELOU, 1998).

Também podem ocorrer outros minerais resistentes à ação das intempéries (minerais secundários), como aqueles designados genericamente de minerais pesados, dos quais são encontrados com maior freqüência os seguintes: magnetita, ilmenita, rutilo, turmalina, zircão, etc. O anatásio, geralmente, encontra-se associado ao rutilo e à hematita.

Outro mineral, a rigor, uma associação de minerais, que freqüentemente ocorre nos latossolos, sobretudo na fração pedregulho, é a laterita ou concreção laterítica, constituída essencialmente de óxidos hidratados de ferro e alumínio. A essa substância, associam-se freqüentemente a magnetita, a ilmenita, a hematita e, sobretudo, o quartzo.

Similarmente ao caso da fração areia, a constituição mineralógica da fração silte é quase sempre muito simples, sendo nítida a predominância do quartzo. É bastante freqüente a presença de torrões de argila e a laterita também pode ocorrer nessa fração, contudo é difícil sua distinção dos primeiros.

Os principais constituintes da fração argila, ou seja, da parte formada por grãos de diâmetro inferior a 0,002 mm são classificados em constituintes minerais (argilominerais, óxidos e hidróxidos de ferro e/ou alumínio) e constituintes orgânicos (húmus ou ácidos húmicos).

A fração argila dos latossolos caracteriza-se por conter elevada porcentagem de óxidos e hidróxidos de ferro e alumínio. $\mathrm{O}$ argilo-mineral, geralmente presente na fração argila dos latossolos, é a caulinita.

A caulinita possui estrutura atômica, formada por uma repetição sucessiva de pacotes, constituídos de uma camada de tetraedros de sílica e de uma camada de octaedros de alumina, sendo que estes pacotes estão ligados por força atômica do tipo hidrogênio. 
Os argilo-minerais caracterizam-se por possuir uma série de propriedades peculiares, das quais destacam-se (NOGAMI, 1995):

a) enorme área específica, decorrente sobretudo de suas dimensões diminutas (da ordem de micrômetros a nanômetros) e de sua forma lamelar e/ou alongada;

b) cargas elétricas predominantemente negativas, que lhes proporcionam capacidade de troca catiônica, quando em meio aquoso e, também, condicionam o grau de acidez ou pH do solo;

c) adsorção de cátions devido à elevada área superficial específica e predominância da cargas elétricas negativas na superfície de suas partículas.

- Fluorescência de raios X:

Os resultados obtidos para a amostra composta avaliada pela análise de fluorescência de raios X estão apresentados na tabela 5.1.3.

Tabela 5.1.3 - Fluorescência de Raios-X

\begin{tabular}{|c|c|}
\hline Formas Químicas & Teor $(\%)$ \\
\hline $\mathrm{SiO}_{2}$ & 61,70 \\
\hline $\mathrm{Al}_{2} \mathrm{O}_{3}$ & 16,80 \\
\hline $\mathrm{Fe}_{2} \mathrm{O}_{3}$ & 8,31 \\
\hline $\mathrm{K}_{2} \mathrm{O}$ & 2,58 \\
\hline $\mathrm{MgO}$ & 1,30 \\
\hline $\mathrm{TiO}_{2}$ & 1,00 \\
\hline $\mathrm{CaO}$ & 0,42 \\
\hline $\mathrm{Na}_{2} \mathrm{O}$ & 0,32 \\
\hline $\mathrm{PbO}$ & 0,16 \\
\hline $\mathrm{P}_{2} \mathrm{O}_{5}$ & 0,12 \\
\hline $\mathrm{BaO}$ & 0,08 \\
\hline $\mathrm{MnO}$ & 0,07 \\
\hline $\mathrm{ZrO}_{2}$ & 0,07 \\
\hline $\mathrm{ZnO}$ & 0,06 \\
\hline $\mathrm{SO}_{3}$ & 0,04 \\
\hline $\mathrm{CuO}$ & 0,03 \\
\hline $\mathrm{Rb}_{2} \mathrm{O}$ & 0,03 \\
\hline $\mathrm{Cr}_{2} \mathrm{O}_{3}$ & 0,02 \\
\hline $\mathrm{CO}_{3} \mathrm{O}_{4}$ & 0,02 \\
\hline $\mathrm{V}_{2} \mathrm{O}_{5}$ & 0,01 \\
\hline $\mathrm{SrO}$ & 0,01 \\
\hline $\mathrm{Y}_{2} \mathrm{O}_{3}$ & $\begin{array}{l}0,01 \\
0\end{array}$ \\
\hline $\mathrm{Nb}_{2} \mathrm{O}_{5}$ & 0,00 \\
\hline $\mathrm{PF}(*)$ & 10,10 \\
\hline
\end{tabular}

(*) PF: Perda ao fogo a $1.050^{\circ} \mathrm{C}$ 
A análise química semi-quantitativa mostra uma predominância de silício, alumínio e ferro.

A predominância de silício deve-se ao fato de que todos os argilo-minerais e a maioria dos minerais formadores de rochas e solos possuem silício em sua composição.

A presença de aproximadamente $17 \%$ de alumínio deve-se aos argilo-minerais, sendo a caulinita um silicato aluminoso.

O material contaminado apresenta elevado teor de ferro em sua composição (8,31\%), tendo sido detectada a hematita na difratometria de raios-X, uma das principais fontes deste elemento, juntamente com a magnetita, limonita, ilmenita, siderita e pirita. A limonita é uma mistura de vários hidróxidos de ferro, incluindo a goetita, lepidocrocita e hidrolepidocrocita, além de impurezas como a matéria argilosa e o quartzo ${ }^{4}$. Por ser um composto amorfo não é passível de detecção nos ensaios de difratometria de raios-X.

O potássio é proveniente da muscovita e do ortoclásio e o titânio está na composição do anatásio, mineral geralmente associado à hematita.

\subsection{Resultados obtidos no ensaio de lixiviação dos metais com a utilização do ácido sulfúrico concentrado}

No ensaio de lixiviação dos metais pesados, presentes em 4 litros de suspensão de material contaminado preparado com $25 \%$ de teor de sólidos, com a utilização de ácido sulfúrico concentrado, realizados em triplicata, foram coletadas amostras em cada valor de $\mathrm{pH}$, partindo-se de 8 até 2, totalizando, dessa forma, 21 amostras.

Foram separadas as fases sólida e líquida da suspensão, para que na primeira fossem determinados os teores dos metais $\mathrm{B}, \mathrm{Cd}, \mathrm{Pb}$ e $\mathrm{Zn}$ presentes no solo bruto $(\mathrm{pH}$ 8) e remanescentes pós tratamento $(\mathrm{pH}$ entre 7 e 2) e na segunda, as concentrações extraídas (lixiviados) da matriz sólida pela ação do agente lixiviante.

$\mathrm{Na}$ tabela a seguir, são relacionadas as amostras coletadas e os respectivos teores de $\mathrm{B}, \mathrm{Cd}, \mathrm{Pb}$ e $\mathrm{Zn}$ detectados na fase sólida, além dos volumes de ácido sulfúrico concentrado e das soluções de hidróxido de sódio 0,2 e $6 \mathrm{M}$, necessários à

\footnotetext{
${ }^{4}$ http://www.unb.br/ig/cursos/FundMineral/FundMineral_Apostila5.pdf
} 
estabilização do $\mathrm{pH}$ requerido em cada etapa. $\mathrm{O}$ consumo médio de ácido sulfúrico por quilo de solo seco é mostrado na figura 5.2.1.

As determinações químicas foram realizadas em triplicata. Os teores detectados por reator, em cada valor de $\mathrm{pH}$, representam a média dos valores obtidos.

Nas figuras 5.2.2 e 5.2.4, são ilustrados os teores de $\mathrm{Pb}$ e $\mathrm{Zn}$ identificados na fase sólida das amostras, conforme apresentados na tabela 5.2.1. Os teores de $\mathrm{B}$ e $\mathrm{Cd}$ apresentaram-se abaixo do limite de detecção do método analítico, exceto nas amostras dos reatores 1 e $2 \mathrm{em} \mathrm{pH} 8$ e no reator $1 \mathrm{em} \mathrm{pH} \mathrm{7,} \mathrm{nas} \mathrm{quais} \mathrm{o} \mathrm{B}$ foi detectado em provável erro na determinação analítica, sendo estes resultados, dessa forma, descartados. 


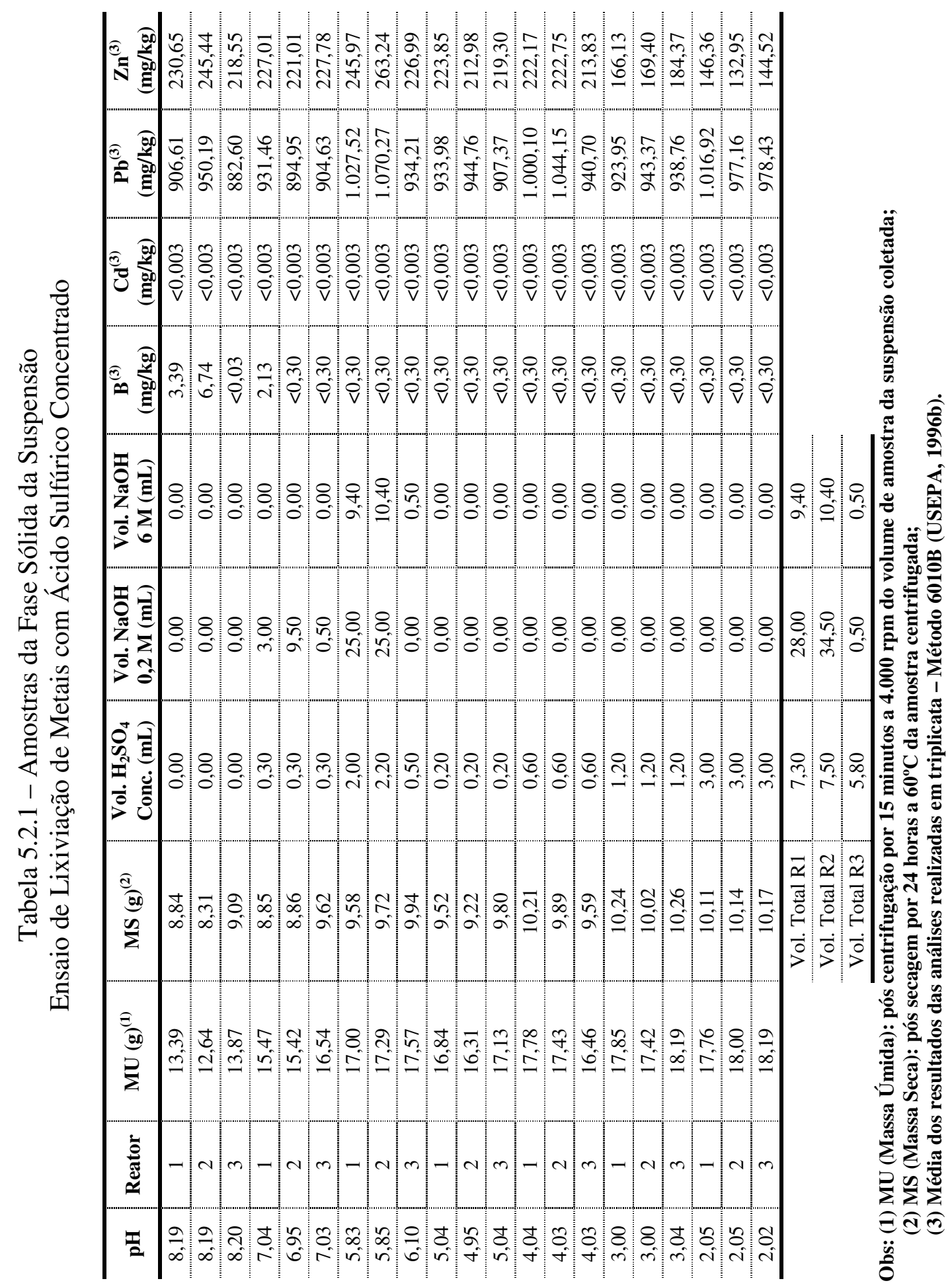




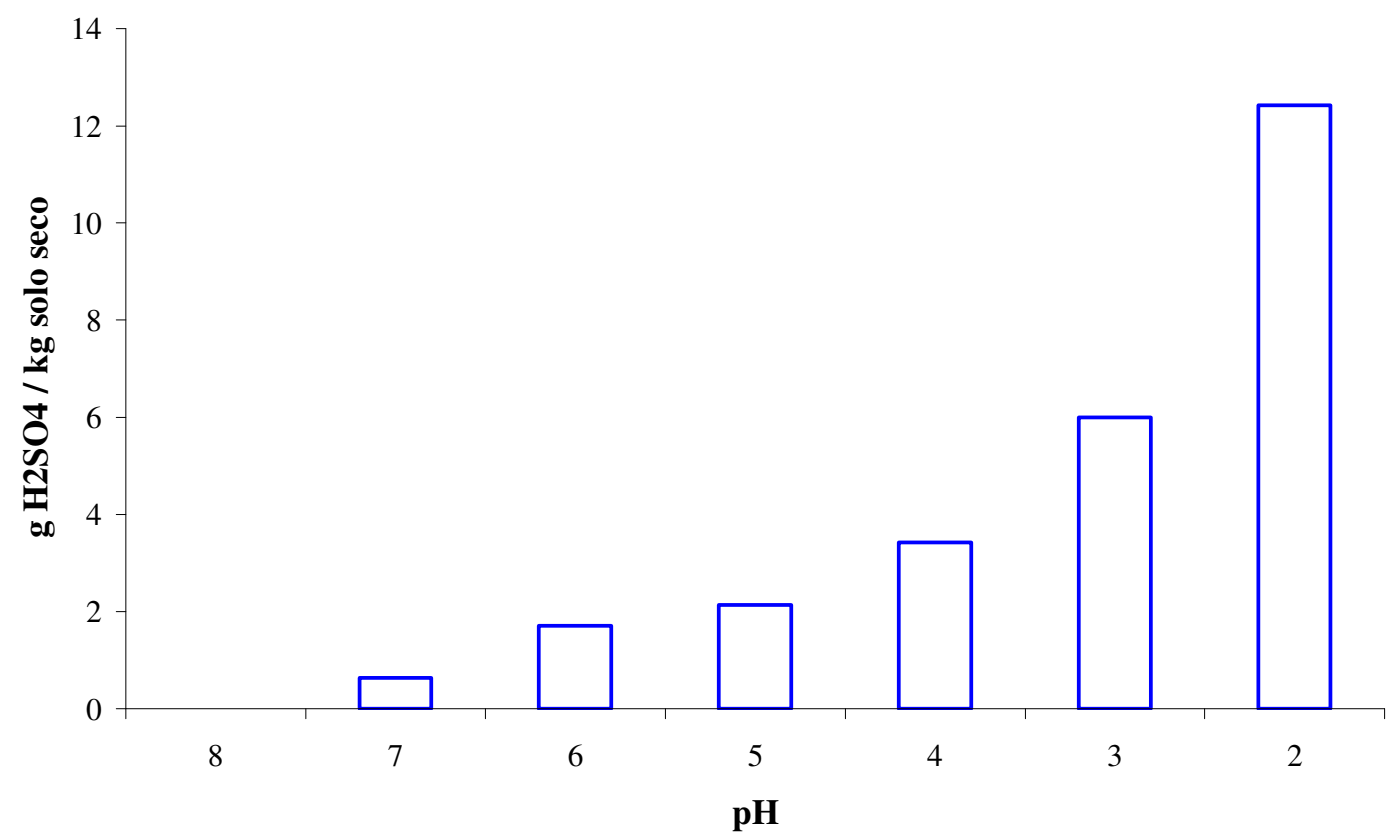

Figura 5.2.1 - Consumo de Ácido Sulfúrico Concentrado por Quilo de Solo Seco

Os valores encontrados referem-se à média dos ensaios realizados em triplicata, exceto para o ensaio em $\mathrm{pH}$ 6, no qual devido à errônea superdosagem do ácido sulfúrico na suspensão dos reatores 1 e 2, foi necessária a reestabilização do meio, através da adição das soluções de hidróxido de sódio 0,2 e $6 \mathrm{M}$. Assim sendo, somente foi considerado o consumo do ácido observado na suspensão do reator 3 .

A massa de ácido sulfúrico concentrado por quilo de solo seco da suspensão foi determinada por:

Massa de $\mathrm{H}_{2} \mathrm{SO}_{4}$ concentrado por massa de solo seco $(\mathrm{g} / \mathrm{kg})=[(\mathrm{a} / 1.000) \times \mathrm{b}$ x $1.000] / \mathrm{c}$

Onde:

$\mathrm{a}=$ volume de $\mathrm{H}_{2} \mathrm{SO}_{4}$ concentrado consumido (L)

$\mathrm{b}=$ densidade do $\mathrm{H}_{2} \mathrm{SO}_{4}$ concentrado $(1,84 \mathrm{~kg} / \mathrm{L})$

$\mathrm{c}=$ massa de solo seco da suspensão com $25 \%$ de teor de sólidos $(0,859 \mathrm{~kg})$ 
Os teores de $\mathrm{Pb}$ detectados nos diferentes valores de $\mathrm{pH}$ (figura 5.2.2) não evidenciam a transferência desse elemento da matriz sólida para a fase líquida, sendo que em $\mathrm{pH}$ inferior a 6 houve tendência de acréscimo deste teor. O elevado desvio padrão dos resultados das amostras em valores de $\mathrm{pH}$ de 6,0 e 4,0 pode ser incumbido à heterogeneidade do material estudado.

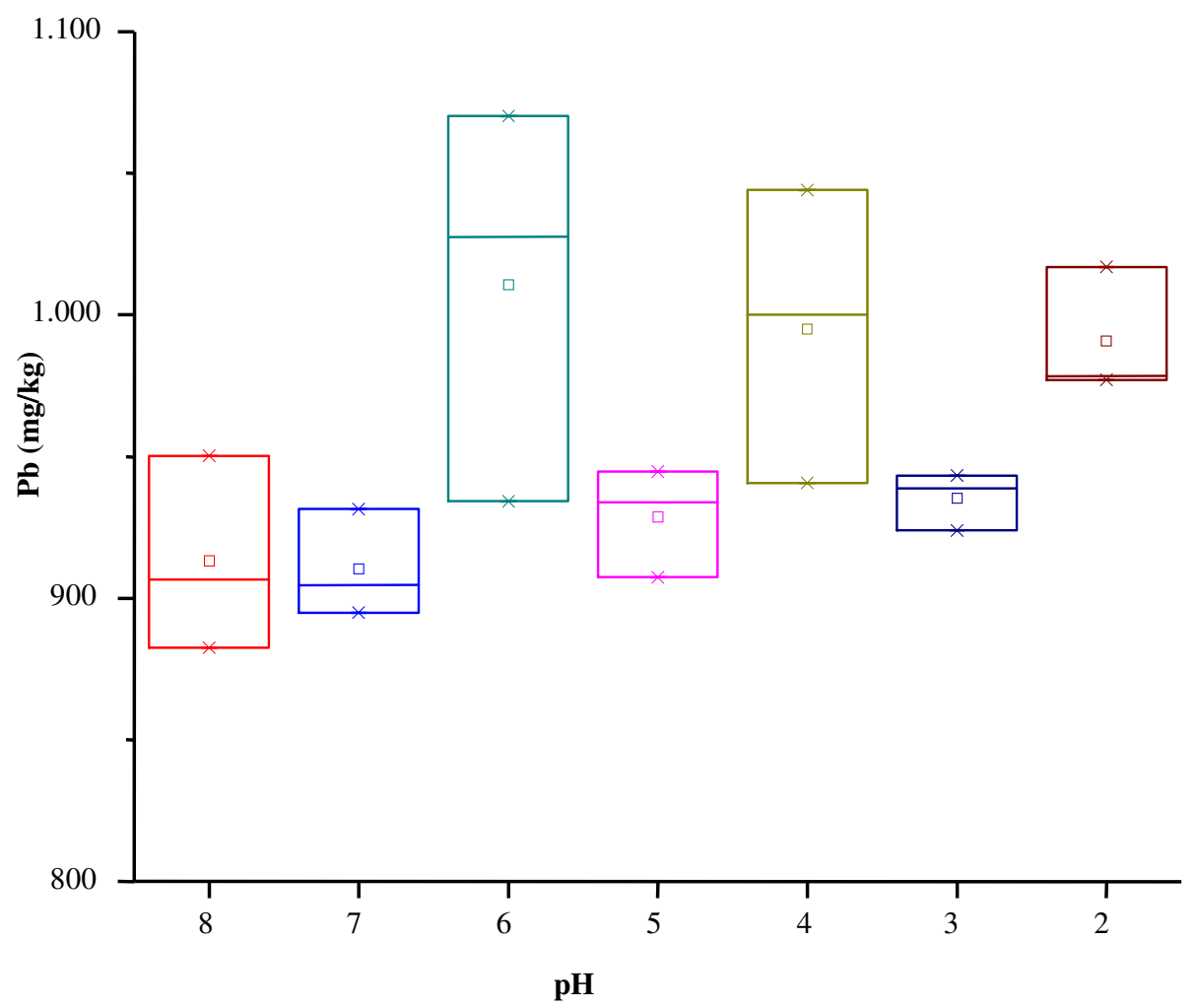

Figura 5.2.2 - Teores Mínimos, Médios e Máximos de Pb Detectados na Fase Sólida da Suspensão Ensaio de Lixiviação de Metais com Ácido Sulfúrico Concentrado

Com a adição do ácido sulfúrico à suspensão, provavelmente ocorreu a formação da espécie $\mathrm{PbSO}_{4}$, que é insolúvel e foi precipitada ${ }^{5}$. A tabela 5.2.2 mostra os teores de chumbo na fase sólida com e sem a acidificação. Ela indica o aumento de aproximadamente $21 \%$ da massa de chumbo na fase sólida da suspensão em pH igual a 2,0 em relação ao detectado na suspensão sem acidificação, sendo esse acréscimo, provavelmente, produzido pela precipitação das espécies inicialmente dissolvidas na suspensão.

\footnotetext{
${ }^{5}$ Solubilidade do sulfato de chumbo em água a $20^{\circ} \mathrm{C}\left(\mathrm{Kps}=1,6 \times 10^{-8}\right)=40 \mathrm{mg} / \mathrm{L}$.
} 
Tabela 5.2.2 - Massa de Pb na Fase Sólida das Suspensões sem Acidificação e Tratadas com Ácido Sulfúrico Concentrado

\begin{tabular}{c|c|c}
\hline pH & $\begin{array}{c}\text { Massa de Pb na Fase } \\
\text { Sólida (mg) }\end{array}$ & $\begin{array}{c}\text { Percentual de Redução ou } \\
\text { Acréscimo em Relação à Suspensão } \\
\text { sem Acidificação (\%) }\end{array}$ \\
\hline 8,0 & 583,88 & - \\
\hline 7,0 & 600,28 & 2,81 \\
\hline 6,0 & 685,85 & 17,46 \\
\hline 5,0 & 633,38 & 8,48 \\
\hline 4,0 & 687,51 & 17,75 \\
\hline 3,0 & 653,00 & 11,84 \\
\hline 2,0 & 704,61 & 20,68 \\
\hline
\end{tabular}

Obs: (1) Massa de Pb na Fase Sólida (mg) = massa de solo seco na fase sólida da suspensão $(\mathrm{kg}) \mathrm{x}$ teor do metal detectado na amostra da fase sólida (média dos ensaios em triplicata) $(\mathrm{mg} / \mathrm{kg})$.

Segundo FULLER (1983) apud BOURG (1995), o Cu e o Pb são os metais menos móveis e os mais dificilmente extraídos de uma matriz sólida. Os argilo-minerais, componentes dos latossolos, possuem partículas com elevada área específica e de permanente carga elétrica negativa (ALLOWAY, 1995), que proporcionam condições ideais à adsorção dos cátions metálicos.

As interações entre os metais pesados e os colóides dos solos (argila, substâncias húmicas ou a combinação de ambas) são devidas à troca iônica, adsorção na superfície dos colóides e reações de quelação, sendo que a retenção dos metais pesados, proporcionada por estes colóides, varia com a força iônica, pH, características dos argilo-minerais, grupos funcionais e cátions competidores (EVANGELOU, 1998).

A superfície dos argilo-minerais apresenta três potenciais grupos funcionais. $\mathrm{O}$ primeiro é o -Al-OH (octaedro) ou aluminol, com $\mathrm{pKa}^{6}$ próximo a 5; o segundo é o silanol (-Si-OH) (tetraedro), com pKa próximo a 9, e o terceiro é o -Si-Al- $\mathrm{OH}_{2}$, onde o OH é compartilhado entre as camadas tetraedro e octaedro e o pKa está entre 6 e 7. A equação de Henderson-Hasselbalch pode ser utilizada para ilustrar o comportamento dos grupos funcionais da superfície dos minerais: uma vez ocorrida a dissociação do grupo funcional -Al-OH, ocorre a formação do -Al- ${ }^{-}$, que atrai cátions e forma complexos na superfície dos minerais como o - $\mathrm{Al}-\mathrm{O} \cdot \mathrm{nH}_{2} \mathrm{OM}$, onde o M representa qualquer cátion metálico. De acordo com a equação, um grupo

\footnotetext{
${ }^{6} \mathrm{pKa}=-\log \mathrm{Ka}$, onde Ka é a constante de dissociação de um ácido fraco.
} 
funcional da superfície com um pKa igual a 5 indica que em $\mathrm{pH} 5$, metade da superfície do mineral está dissociada e, no entanto, sua carga elétrica negativa é metade do potencial máximo. Em aproximadamente duas unidades de $\mathrm{pH}$ superiores ao pKa, todos os grupos da superfície são dissociados e, dessa forma, a carga elétrica negativa da superfície está próxima do valor máximo, ao passo que em duas unidades de $\mathrm{pH}$ abaixo do valor do $\mathrm{pKa}$, todos os grupos funcionais da superfície estão protonados e assim, a carga negativa da superfície do mineral está próxima a zero, sendo que qualquer nova diminuição no valor do $\mathrm{pH}$ pode induzir a reversão da carga elétrica pela formação do $-\mathrm{Al}-\mathrm{OH}_{2}{ }^{+}$, que permite a formação de complexos com ânions (ex.: $\mathrm{Cl}^{-}$e $\mathrm{SO}_{4}{ }^{2-}$ ) na superfície dos minerais. Os grupos funcionais -Al-OH e -Al-Si-OH são conhecidos por exibirem um potencial de reversão da carga da superfície em diversos valores de $\mathrm{pH}$, característica não exibida pelo grupo -Si-OH (EVANGELOU, 1998).

Embora o diagrama $\mathrm{EH} / \mathrm{pH}$ não possa ser empregado diretamente para avaliar a especiação dos metais no solo estudado, ele auxilia na interpretação dos resultados.

O diagrama, ilustrado na figura 5.2.3, indica o comportamento do elemento chumbo de acordo com a variação do $\mathrm{pH}$ e das condições do meio. Conforme pode ser observado, a formação do sulfato de chumbo é favorecida em meio ácido e ligeiramente oxidado. Em $\mathrm{pH}$ inferior a 1, é predominante a presença do íon $\mathrm{Pb}^{2+}$, considerada a espécie mais tóxica desse elemento. A partir do $\mathrm{pH}=5,0$ e em ambientes oxidados, prevalece a presença das espécies que permanecem adsorvidas e complexadas às partículas do solo e dos sedimentos como o carbonato e os óxidos de chumbo. A galena (PbS), minério fonte do elemento chumbo, ocorre em ambientes oxidados e de menores valores de $\mathrm{pH}$, como também sob condições redutoras e alcalinas.

Pelos experimentos de extração seqüencial realizados por SILVA (2001), verificouse que a maior parte do chumbo detectado nas amostras de solo coletadas em duas áreas da Região dos Lagos de Santa Gertrudes (Áreas de Referência e de Estudos de Detalhe) estava aderida aos óxidos e hidróxidos (entre 32,6 e 55\%) e à matéria orgânica (entre 28,6 e 41,3\%). O elemento também ocorreu associado aos carbonatos quando em meio alcalino (até 33,7\%). As frações trocáveis e fracamente ligadas foram pouco expressivas. 
A suspensão de solo estudada foi mantida durante o ensaio sob condições aeróbias, confirmada visualmente pela coloração vermelho-marron, típica de solos com elevadas concentrações de ferro e de ambientes oxidados, sendo o potencial redox (EH) estimado na faixa de $+400 \mathrm{a}+600 \mathrm{mV}$, conforme ALLOWAY (1995).

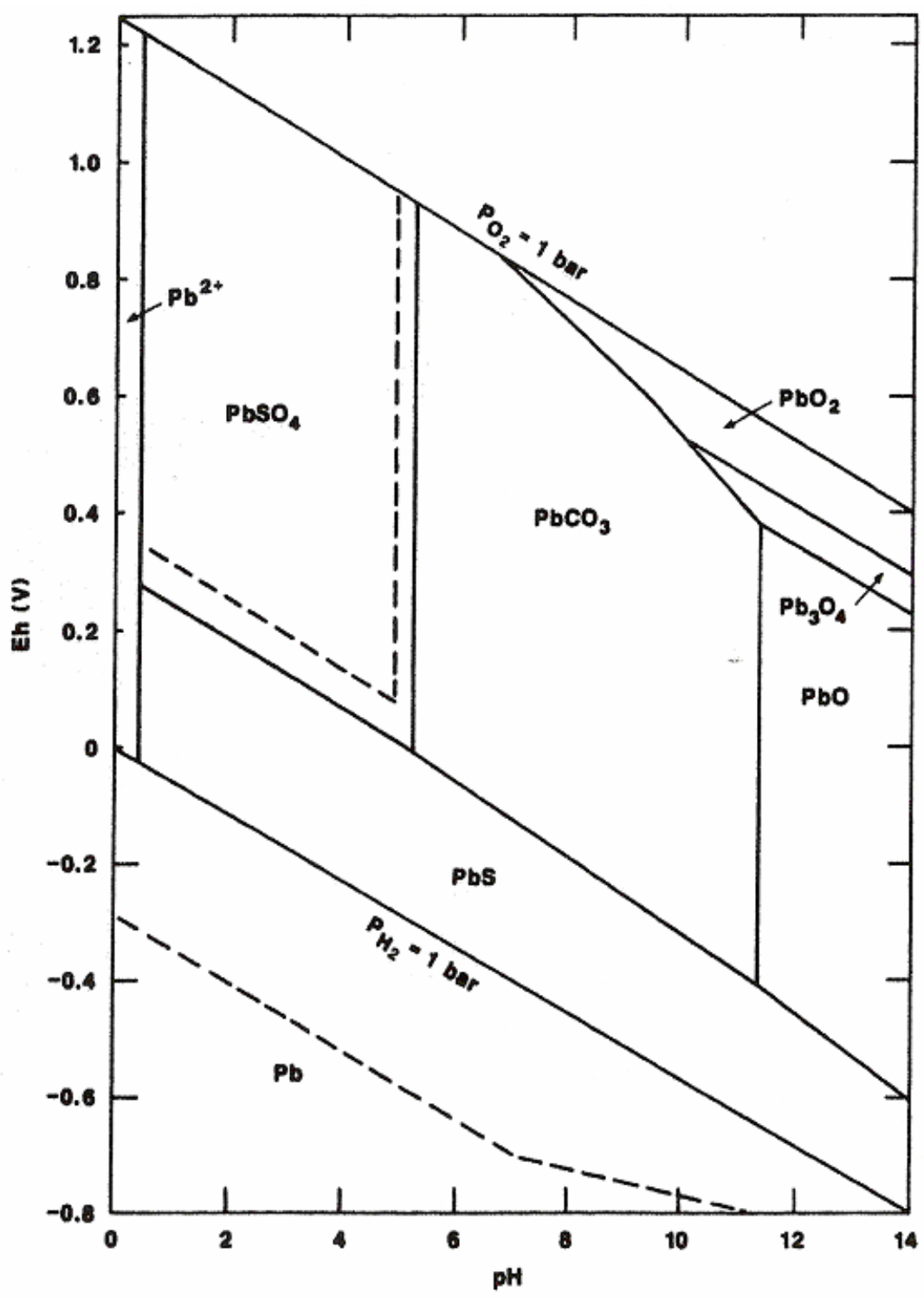

Figura 5.2.3 - Diagrama EH/pH para o Sistema Pb-S-C-O-H (25드. 1 bar) (BROOKINS, 1988) 
Para o elemento Zn, foi detectada a tendência de redução dos teores na fase sólida, à medida que a suspensão foi acidificada (figura 5.2.4).

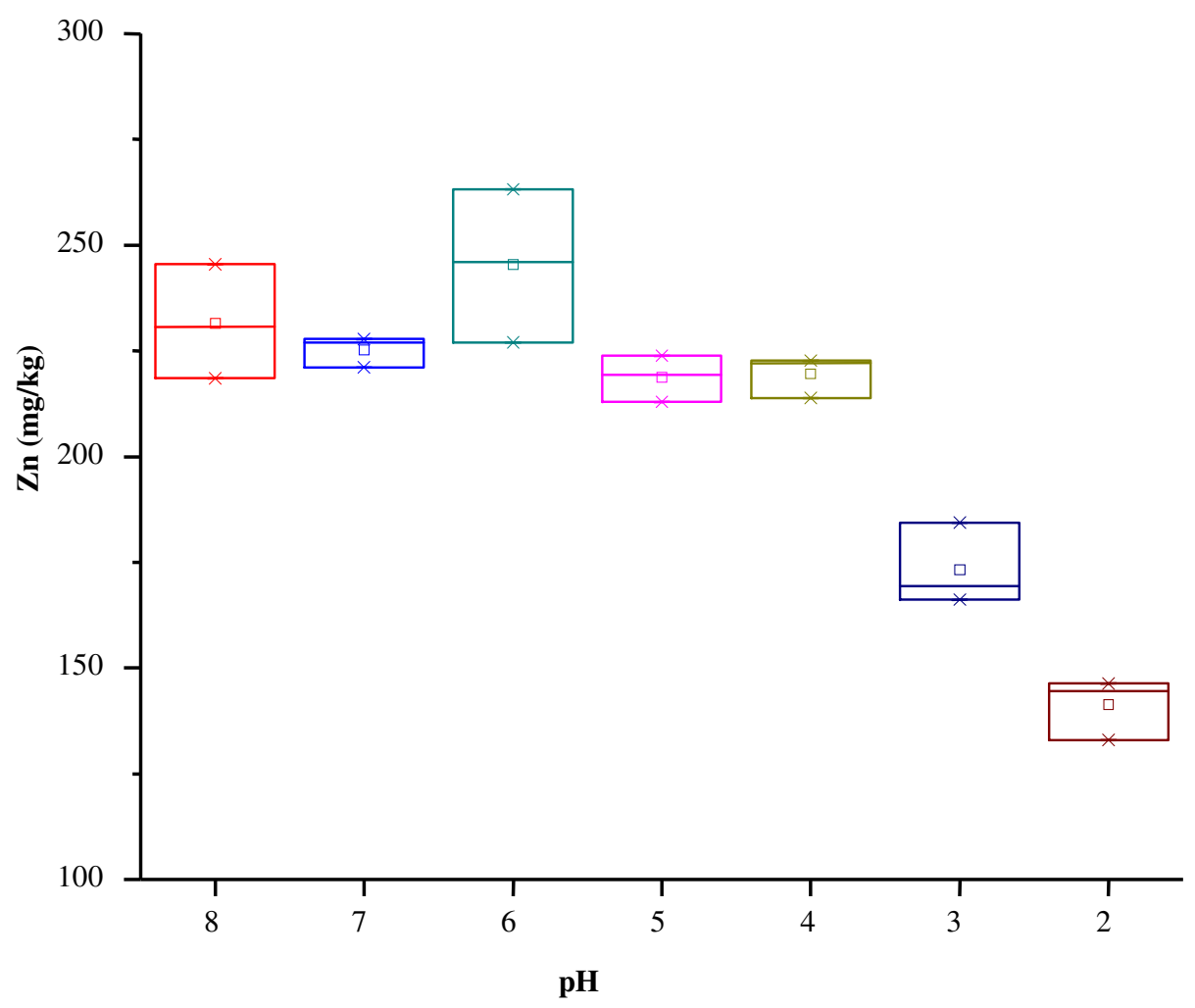

Figura 5.2.4 - Teores Mínimos, Médios e Máximos de Zn Detectados na Fase Sólida da Suspensão Ensaio de Lixiviação de Metais com Ácido Sulfúrico Concentrado

Provavelmente, a adição do ácido sulfúrico produziu a formação da espécie solúvel sulfato de zinco $\left(\mathrm{ZnSO}_{4}\right)$ e liberação dos íons $\mathrm{Zn}^{2+}$. Dessa forma, o elemento zinco, presente em pH 8 e no ambiente oxidado, na forma de hidróxidos $\left(\mathrm{Zn}(\mathrm{OH})_{2}\right)$, carbonatos $\left(\mathrm{ZnCO}_{3}\right)$ e óxidos $\left(\mathrm{ZnO}\right.$ e $\left.\mathrm{ZnO}_{2}\right)$, foi lixiviado da matriz sólida.

Como observado para o elemento chumbo, os experimentos de extração seqüencial realizados por SILVA (2001) identificaram que a maior parte do zinco detectado nas amostras de solo coletadas nas Áreas de Referência e de Estudos de Detalhe estava aderida aos óxidos e hidróxidos (entre 36,5 e 55\%) e à matéria orgânica (entre 28,4 e 50,1\%). A fração associada aos carbonatos foi identificada entre 5,4 e $24,9 \%$ e as frações trocáveis e fracamente ligadas entre 0 e $1,4 \%$ e 1,8 e 6,4\%, respectivamente. O zinco, em geral, apresenta mobilidade relativa mais alta do que a do chumbo. Além disso, os teores de $\mathrm{Zn}$ encontrados no solo das áreas de estudo da Região dos 
Lagos de Santa Gertrudes são inferiores aos detectados para o $\mathrm{Pb}$, conforme pode ser observado na tabela 4.1.1.

A tabela a seguir indica a redução de aproximadamente $32 \%$ da massa de zinco na fase sólida da suspensão em pH igual a 2 em relação ao detectado na suspensão sem acidificação.

Tabela 5.2.3 - Massa de Zn na Fase Sólida das Suspensões sem Acidificação e Tratadas com Ácido Sulfúrico Concentrado

\begin{tabular}{|c|c|c|}
\hline $\mathbf{p H}$ & $\begin{array}{l}\text { Massa de Zn na Fase } \\
\text { Sólida }(\mathbf{m g})^{(1)}\end{array}$ & $\begin{array}{c}\text { Percentual de Redução ou } \\
\text { Acréscimo em Relação à Suspensão } \\
\text { sem Acidificação }(\%)\end{array}$ \\
\hline 8,0 & 148,01 & - \\
\hline 7,0 & 148,53 & 0,35 \\
\hline 6,0 & 166,52 & 12,51 \\
\hline 5,0 & 149,17 & 0,79 \\
\hline 4,0 & 151,81 & 2,57 \\
\hline 3,0 & 120,99 & $-18,26$ \\
\hline 2,0 & 100,48 & $-32,12$ \\
\hline
\end{tabular}

Obs: (1) Massa de Zn na Fase Sólida (mg) = massa de solo seco na fase sólida da suspensão $(\mathrm{kg})$ x teor do metal detectado na amostra da fase sólida (média dos ensaios em triplicata) (mg/kg).

A figura 5.2.5 apresenta o diagrama que indica o comportamento do elemento zinco de acordo com as condições do meio. Observa-se que em ambientes oxidados e em valores de $\mathrm{pH} \leq 7,7$ (ALLOWAY, 1995), ocorre a predominância da espécie móvel $\mathrm{Zn}^{2+}$. 


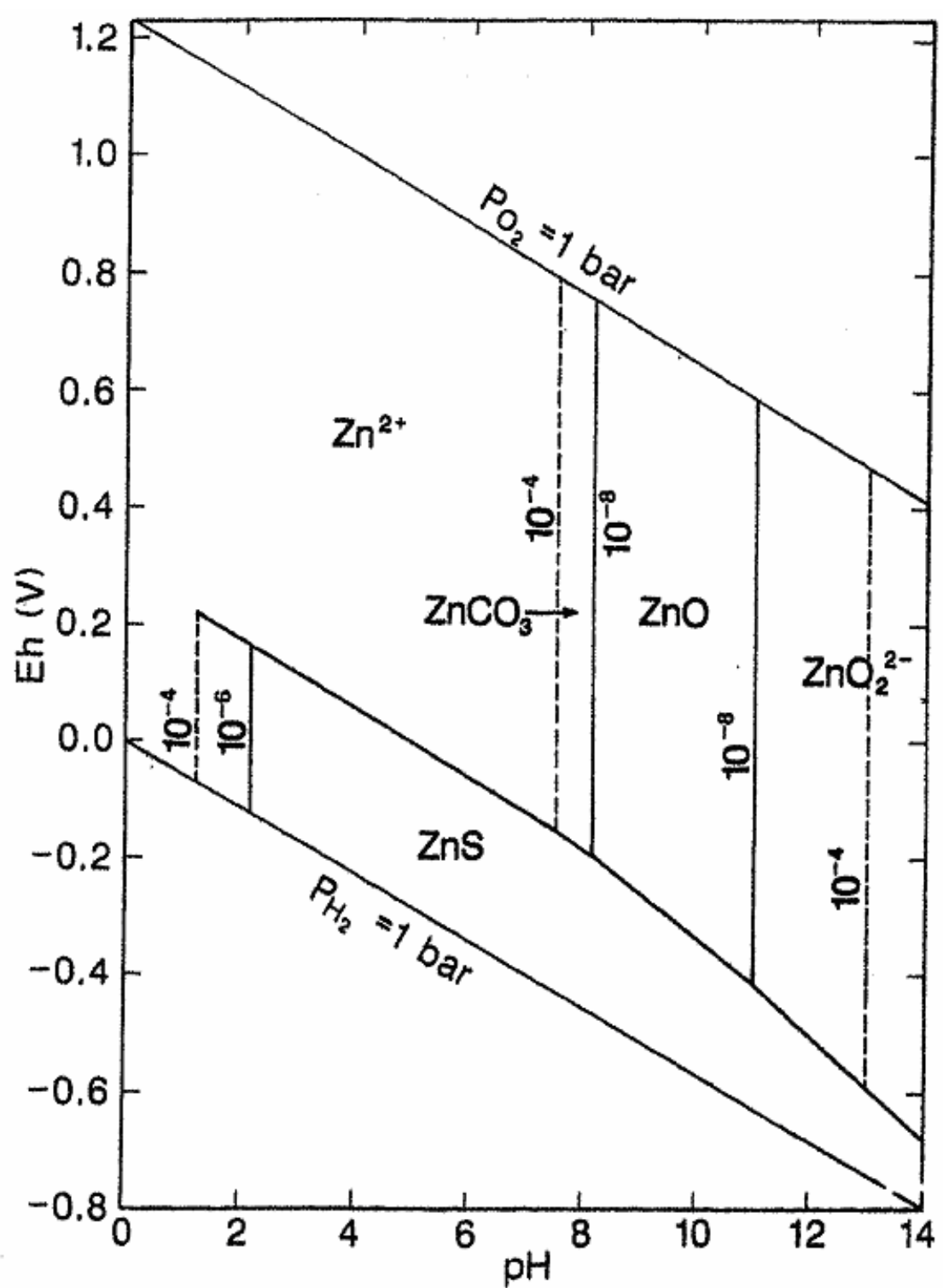

Figura 5.2.5 - Diagrama EH/pH para o Sistema Zn-O-H-S-C (25ㄷ, 1 bar) (BROOKINS, 1988)

Na tabela 5.2.4, são listadas as concentrações de chumbo e zinco, obtidas após a centrifugação da amostra durante 15 minutos a 4.000 rpm e filtração em membrana com porosidade de $0,45 \mu \mathrm{m}$. As concentrações de B detectadas foram descartadas, pois, provavelmente são advindas da lixiviação das paredes do reator de vidro e não do solo bruto, cujo teor apresentou-se abaixo do limite de detecção do método analítico.

Assim como no solo bruto, o Cd não foi detectado na fase líquida da suspensão. 
Tabela 5.2.4 - Amostras da Fase Líquida da Suspensão Ensaio de Lixiviação de Metais com Ácido Sulfúrico Concentrado

\begin{tabular}{|c|c|c|c|}
\hline $\mathbf{p H}$ & Reator & $\mathrm{Pb}(\mathrm{mg} / \mathrm{L})^{(1)}$ & $\mathrm{Zn}(\mathrm{mg} / \mathrm{L})^{(1)}$ \\
\hline 8,19 & 1 & 0,420 & 0,062 \\
\hline 8,19 & 2 & 0,469 & $<0,020$ \\
\hline 8,20 & 3 & 0,540 & $<0,020$ \\
\hline 7,04 & 1 & 0,183 & $<0,020$ \\
\hline 6,95 & 2 & 0,331 & $<0,020$ \\
\hline 7,03 & 3 & 0,153 & $<0,020$ \\
\hline 5,83 & 1 & 0,460 & 0,883 \\
\hline 5,85 & 2 & 0,386 & 0,654 \\
\hline 6,10 & 3 & 0,232 & $<0,020$ \\
\hline 5,04 & 1 & 1,492 & 3,053 \\
\hline 4,95 & 2 & 2,213 & 4,233 \\
\hline 5,04 & 3 & 1,493 & 2,088 \\
\hline 4,04 & 1 & 9,230 & 13,760 \\
\hline 4,03 & 2 & 8,638 & 13,896 \\
\hline 4,03 & 3 & 10,508 & 11,179 \\
\hline 3,00 & 1 & 7,584 & 26,828 \\
\hline 3,00 & 2 & 7,336 & 25,862 \\
\hline 3,04 & 3 & 7,837 & 18,798 \\
\hline 2,05 & 1 & 3,625 & 41,494 \\
\hline 2,05 & 2 & 3,779 & 42,267 \\
\hline 2,02 & 3 & 3,555 & 37,297 \\
\hline
\end{tabular}

Obs: (1) Média dos resultados das análises realizadas em triplicata.

Nas figuras 5.2.6 e 5.2.7, são ilustradas as concentrações de $\mathrm{Pb}$ e $\mathrm{Zn}$ identificadas na fase líquida da suspensão, conforme mostradas na tabela 5.2.4. 


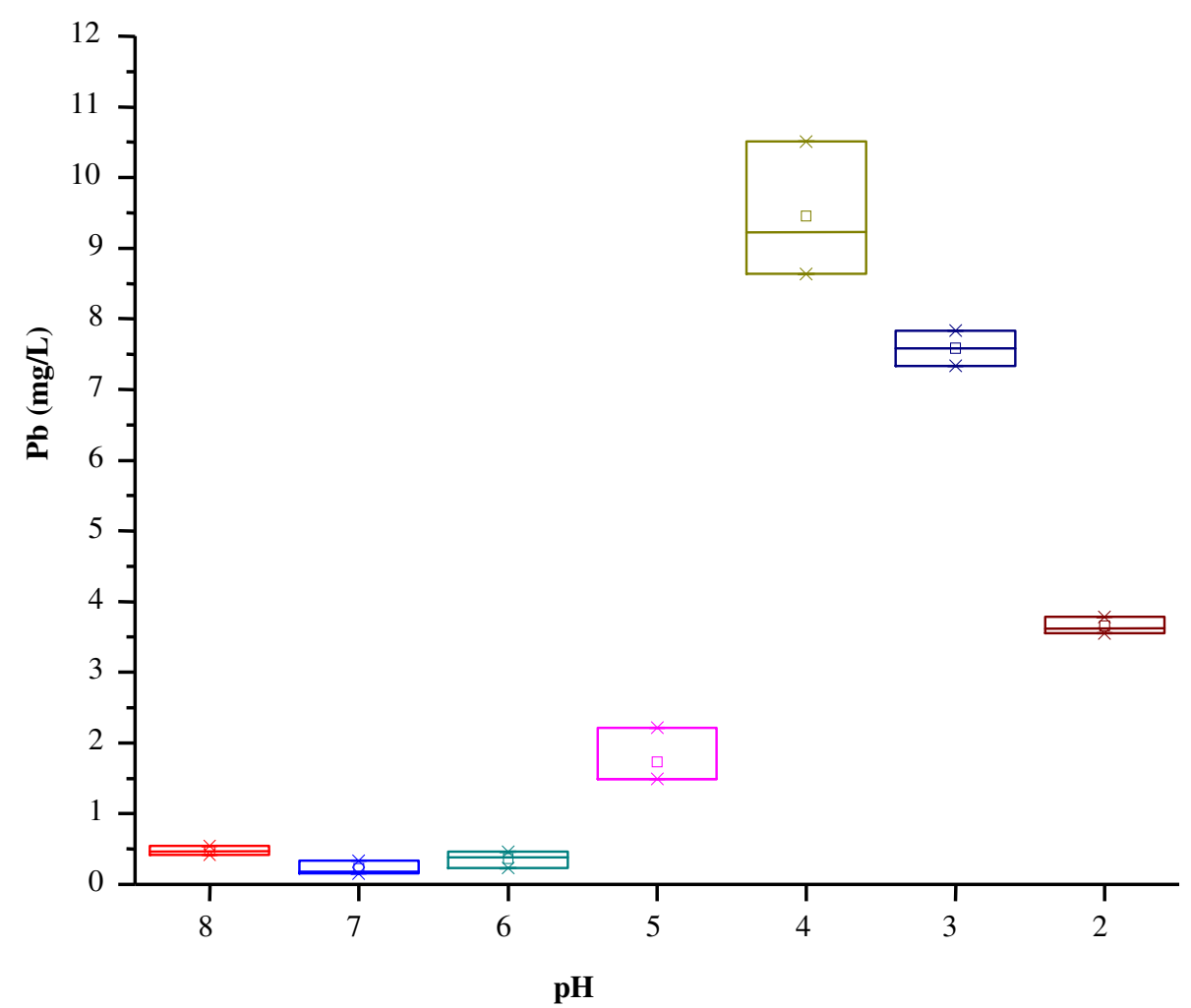

Figura 5.2.6 - Concentrações Mínimas, Médias e Máximas de Pb Detectadas na Fase Líquida da Suspensão - Ensaio de Lixiviação de Metais com Ácido Sulfúrico Concentrado

O gráfico ilustra a tendência do acréscimo da concentração de $\mathrm{Pb}$ na fase líquida da suspensão, sendo que no $\mathrm{pH}$ igual a 4,0 foi detectada a maior concentração. Isto pode ser explicado pela redução da solubilidade do ácido húmico em pH inferior a 4,0 e precipitação deste com o chumbo complexado ao mesmo (JENSEN, OTTOSEN e PEDERSEN, 2006). Esse acréscimo não acompanhou aquele observado para as amostras da fase sólida, nas quais o chumbo, provavelmente precipitado na forma de sulfato de chumbo, produziu o acréscimo dos teores inicialmente identificados na suspensão não acidificada.

$\mathrm{Na}$ tabela a seguir, são apresentadas as massas de chumbo nas suspensões sem acidificação e tratadas com ácido sulfúrico concentrado. 


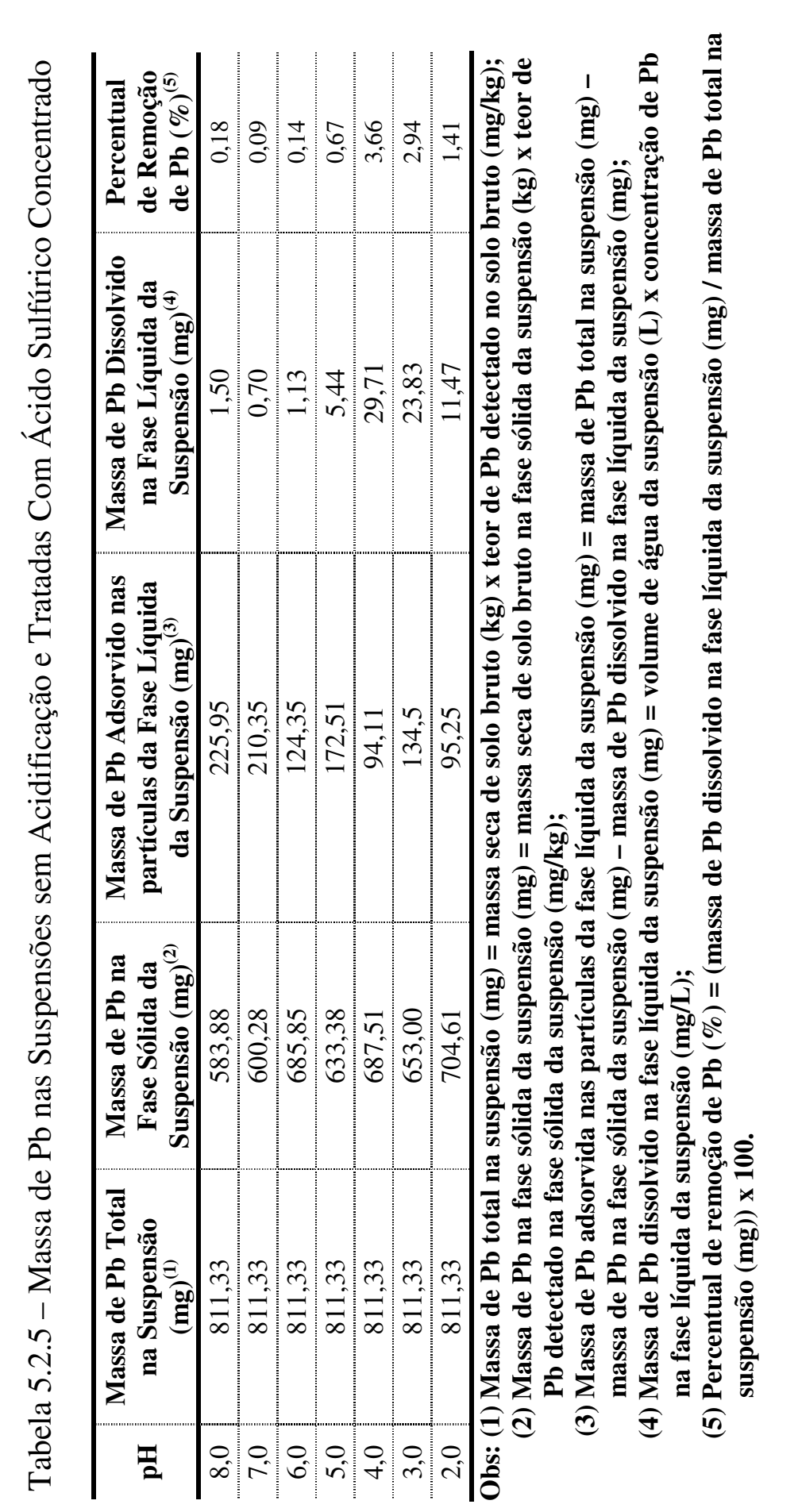

శ్

$\Xi$ व

च

论

อี

음

\& ल

䒿

:

范

o

ธี

율

in

-

:

을 웡

仓

․ छ

응 긍 웅

요

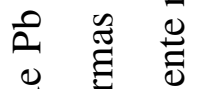

0

䒿 急

ญ्र

ฮี

ฮี้

妀

O

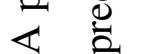




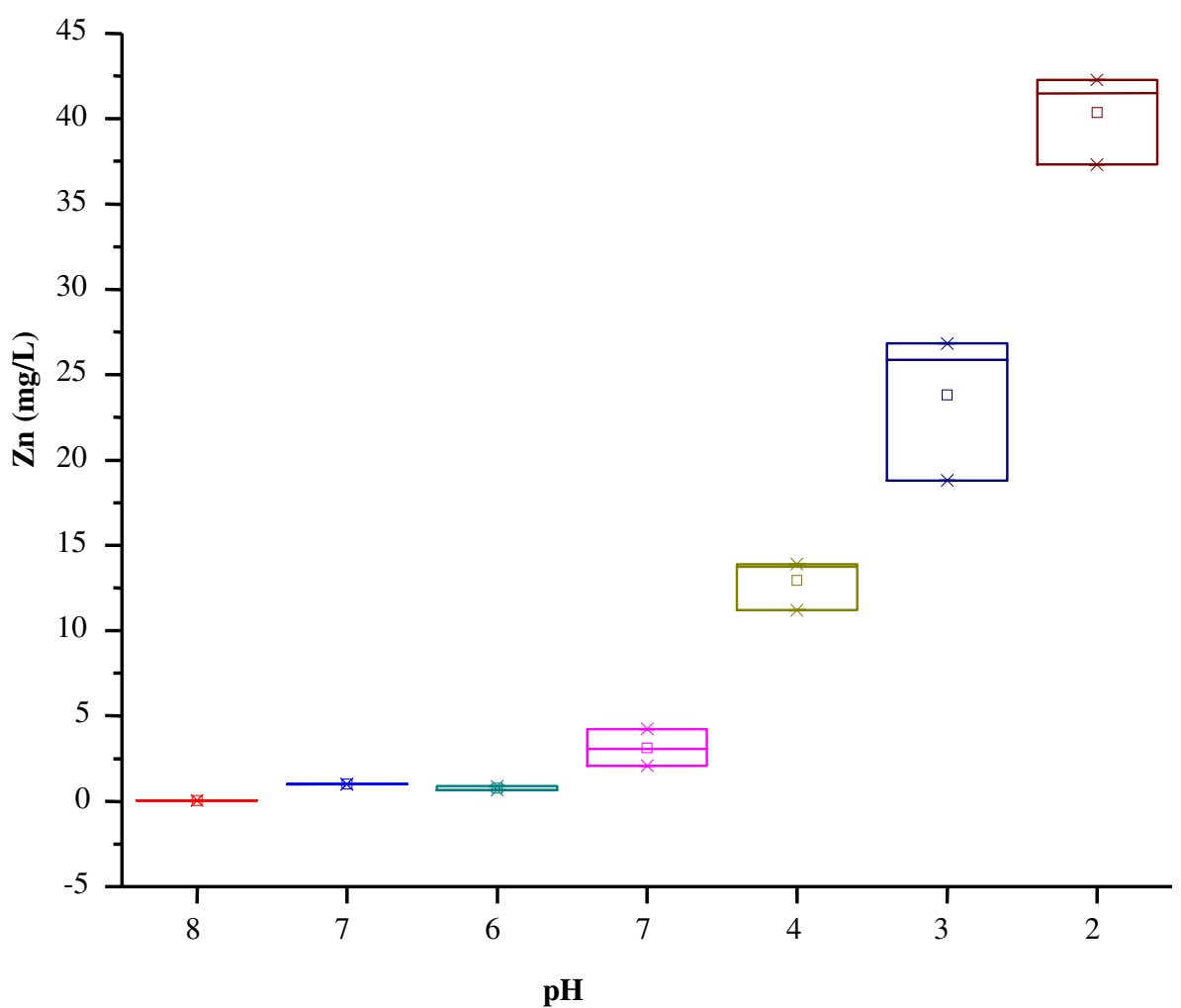

Figura 5.2.7 - Concentrações Mínimas, Médias e Máximas de Zn Detectadas na Fase Líquida da Suspensão - Ensaio de Lixiviação de Metais com Ácido Sulfúrico Concentrado

A lixiviação do $\mathrm{Zn}$ mostrou-se eficiente com o decréscimo do $\mathrm{pH}$, o que coincide com a redução dos teores detectados nas amostras da fase sólida. Conforme pode ser observado no diagrama EH-pH do elemento zinco, a acidificação de um meio oxidado favorece a presença dos íons $\mathrm{Zn}^{2+}$ que são espécies solúveis.

$\mathrm{Na}$ tabela a seguir, são apresentadas as massas de zinco nas suspensões sem acidificação e tratadas com ácido sulfúrico concentrado. Observa-se que a lixiviação do elemento da matriz sólida ocorreu a partir do pH 6,0. 


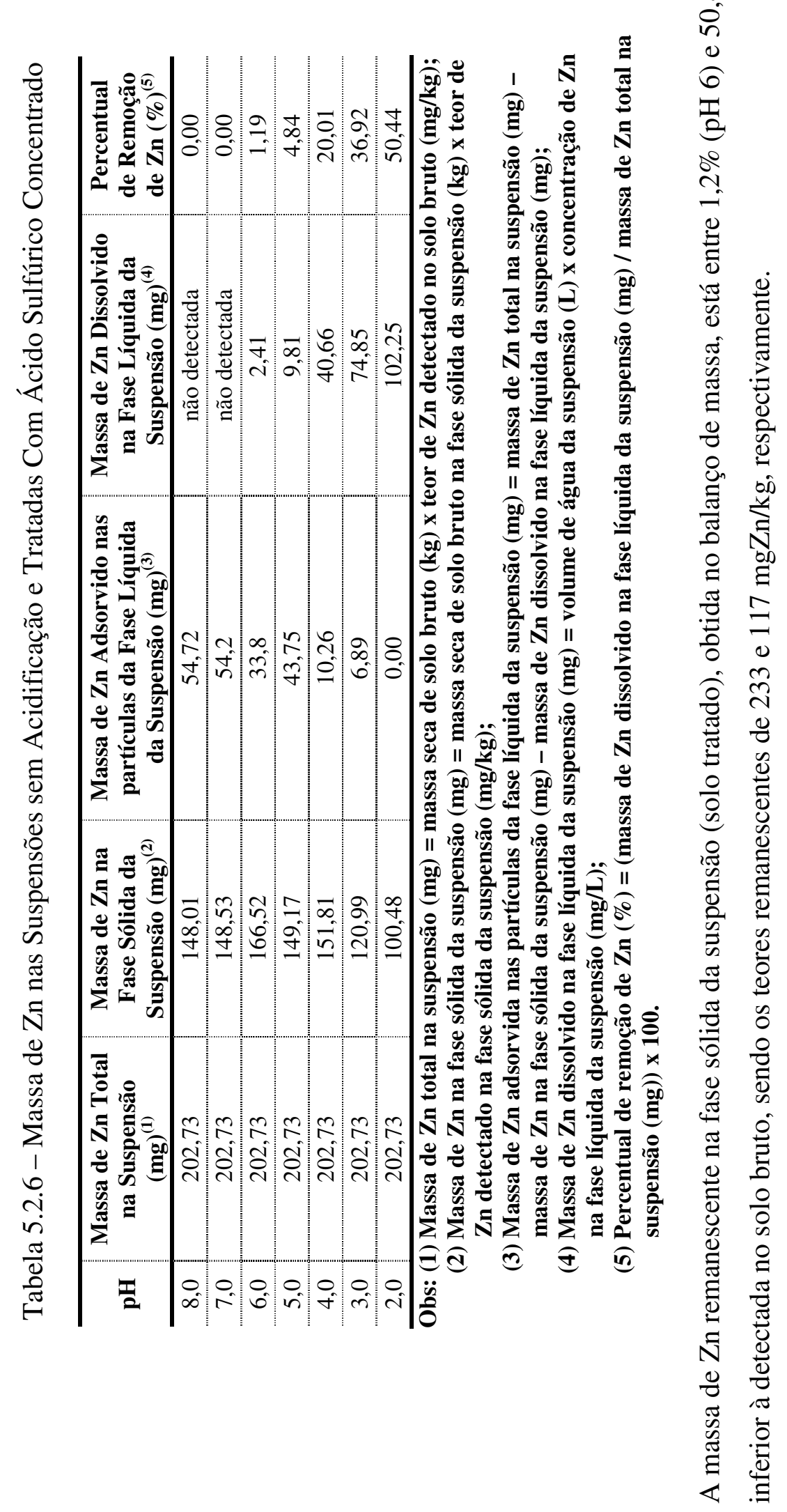




\subsection{Resultados obtidos no ensaio de lixiviação dos metais com a utilização da solução de peróxido de hidrogênio a $30 \%$}

No ensaio de lixiviação dos metais pesados presentes em 4 litros de suspensão de material contaminado preparado com $25 \%$ de teor de sólidos, com a utilização de solução de peróxido de hidrogênio a 30\%, realizados em triplicata, foram coletadas amostras em seis diferentes dosagens, definidas conforme descrito no item 4.2.5, totalizando, dessa forma, 18 amostras.

Foram separadas as fases sólida e líquida da suspensão, para que na primeira fossem determinados os teores dos metais $\mathrm{B}, \mathrm{Cd}, \mathrm{Pb}$ e $\mathrm{Zn}$ remanescentes pós tratamento e na segunda, as concentrações extraídas da matriz sólida pela ação do agente oxidante.

$\mathrm{Na}$ tabela a seguir, são relacionadas as amostras coletadas e respectivos teores de B, $\mathrm{Cd}, \mathrm{Pb}, \mathrm{Zn}$ e de $\mathrm{C}, \mathrm{H}$ e $\mathrm{N}$ detectados no solo bruto e na fase sólida da suspensão.

As determinações químicas dos metais foram realizadas em triplicata e as análises elementares em duplicata. Os teores detectados por reator em cada uma das dosagens da solução de peróxido de hidrogênio a 30\% representam as médias dos valores obtidos.

Nas figuras 5.3.1 e 5.3.3 são ilustrados os teores de $\mathrm{Pb}$ e $\mathrm{Zn}$ identificados na fase sólida das amostras. Os teores de B e Cd apresentaram-se abaixo do limite de detecção do método analítico, exceto em duas amostras da dosagem 4,53\%, nas quais o B foi detectado em provável erro na determinação analítica, sendo estes resultados, dessa forma, descartados. 


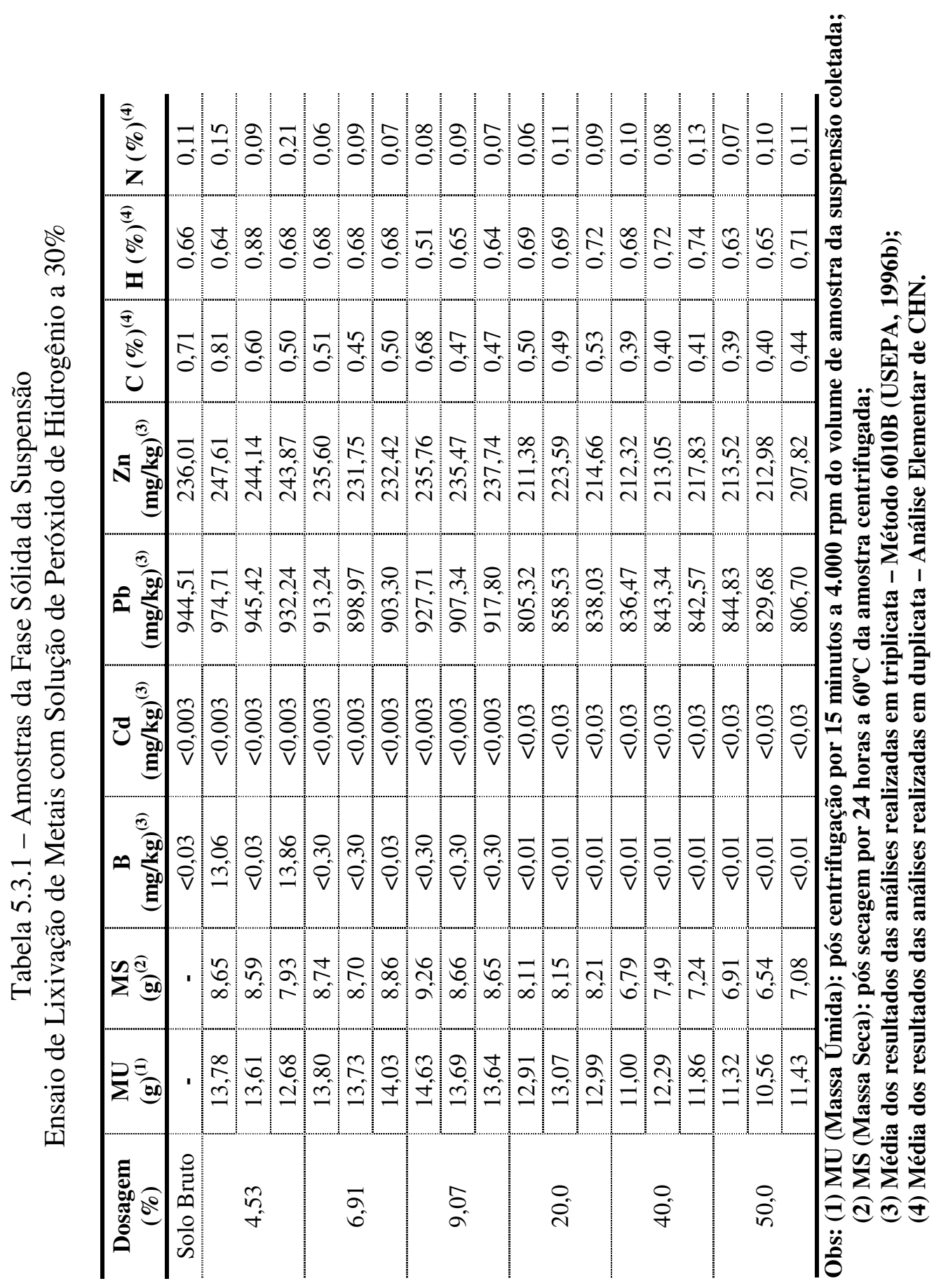




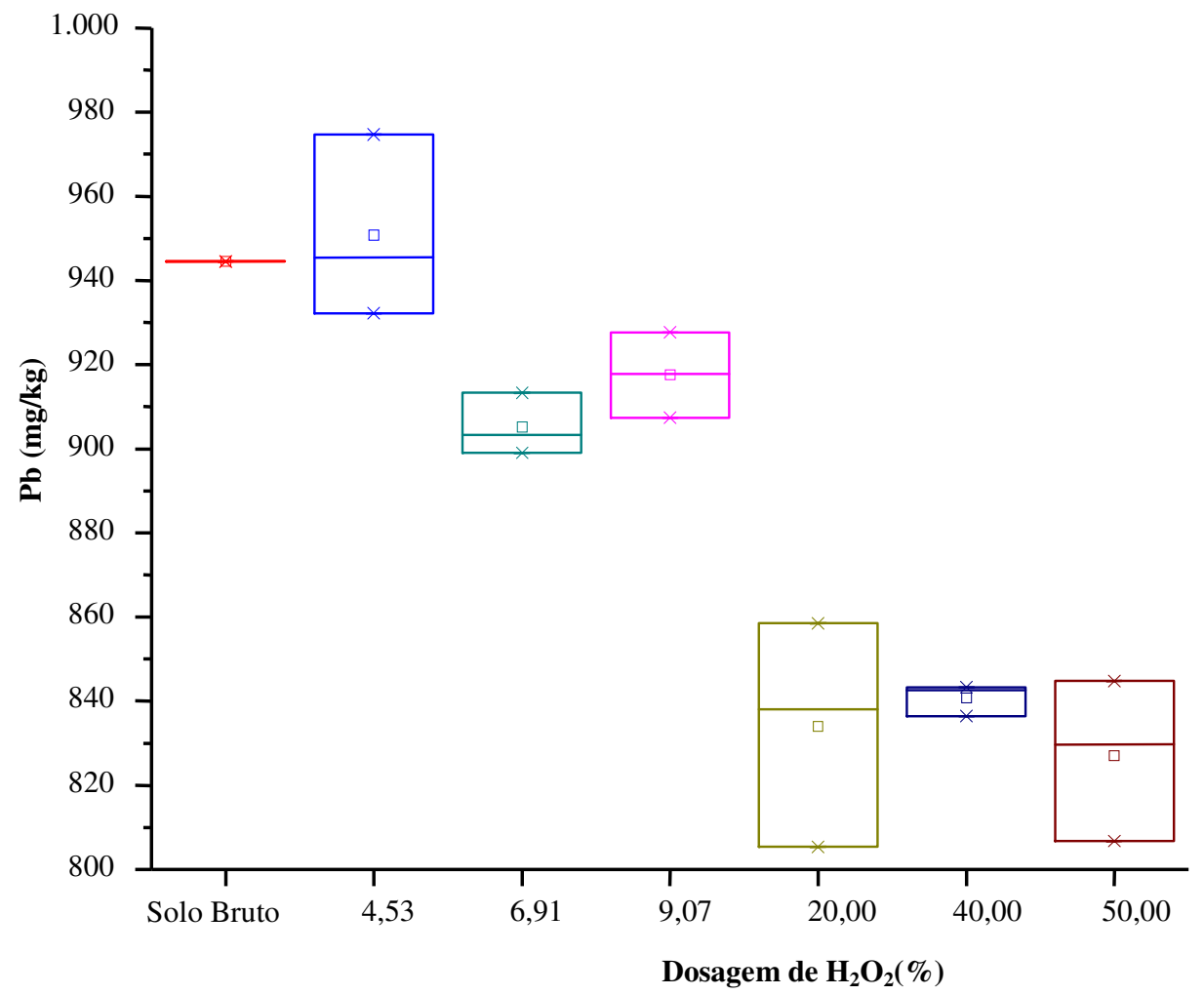

Figura 5.3.1 - Teores Mínimos, Médios e Máximos de Pb Detectados no Solo Bruto e na Fase Sólida da Suspensão - Ensaio de Lixiviação de Metais com Solução de Peróxido de Hidrogênio a 30\%

Conforme valores médios obtidos, evidencia-se a redução dos teores de $\mathrm{Pb}$ da matriz sólida após oxidação do sistema e manutenção dos valores do pH próximos a 8,0.

O elevado desvio padrão dos resultados das amostras das dosagens 4,53, 20 e 50\% pode ser devido à heterogeneidade do material estudado.

A oxidação da matéria orgânica do meio objetivou a liberação dos íons metálicos complexados aos compostos húmicos (polieletrólitos de moderado a elevado peso molecular) e não húmicos (aminoácidos, carboidratos, ácidos orgânicos e lipídios) presentes no solo bruto.

O potencial das substâncias húmicas de formar complexos com os metais pesados deve-se à presença do oxigênio nos grupos funcionais como as carboxilas $(\mathrm{COOH})$, hidroxilas $(\mathrm{OH})$ e carbonilas $(\mathrm{C}=\mathrm{O})$.

Geralmente, as substâncias húmicas formam um forte complexo com a argila e os mecanismos de formação dos complexos diferem de acordo com as características dos argilo-minerais e envolvem a ocorrência de complexos de esferas externas (adsorção física) e de esferas internas (quimiossorção), sendo que os primeiros 
caracterizam-se por uma fraca associação eletrostática entre a superfície elétrica do colóide e um cátion hidratado que pode ser facilmente substituído por outro capaz de formar complexos da mesma natureza. Os complexos de esferas internas são relativamente fortes e formados entre o contato da superfície elétrica do colóide com um cátion não hidratado, sendo que este cátion somente poderá ser substituído por outro que possa formar um complexo idêntico (EVANGELOU, 1998).

A análise elementar indicou a presença de carbono total no solo na faixa de 0,4 a $0,8 \%$, sendo o teor de matéria orgânica estimado entre 0,7 a $1,3 \%$, condizente aos teores geralmente encontrados em solos tropicais da América do Sul (SANCHEZ, 1976 apud ALLOWAY, 1995).

Os complexos coloidais organo-minerais desempenham uma importante função no controle das concentrações dos íons nos solos (ALLOWAY, 1995).

HARTER (1983) apud EVANGELOU (1998) demonstraram que a adsorção do Pb aumenta com o aumento do $\mathrm{pH}$ e é maior no horizonte $\mathrm{A}$ do que no horizonte $\mathrm{B}$ dos solos, pois, no primeiro, geralmente ocorre maior quantidade de matéria orgânica, que possui elevada densidade de carga elétrica negativa e grande dependência do valor do $\mathrm{pH}$.

As três dosagens da solução de peróxido de hidrogênio a $30 \%$ obtidas estequiometricamente proporcionaram a redução de 9,31 e $23 \%$ dos teores de carbono total, e nas amostras com dosagens de 20, 40 e 50\%, foi observada a redução de 29, 43 e 41\%, respectivamente, em relação aos teores detectados no solo bruto, conforme apresentado na figura a seguir. 


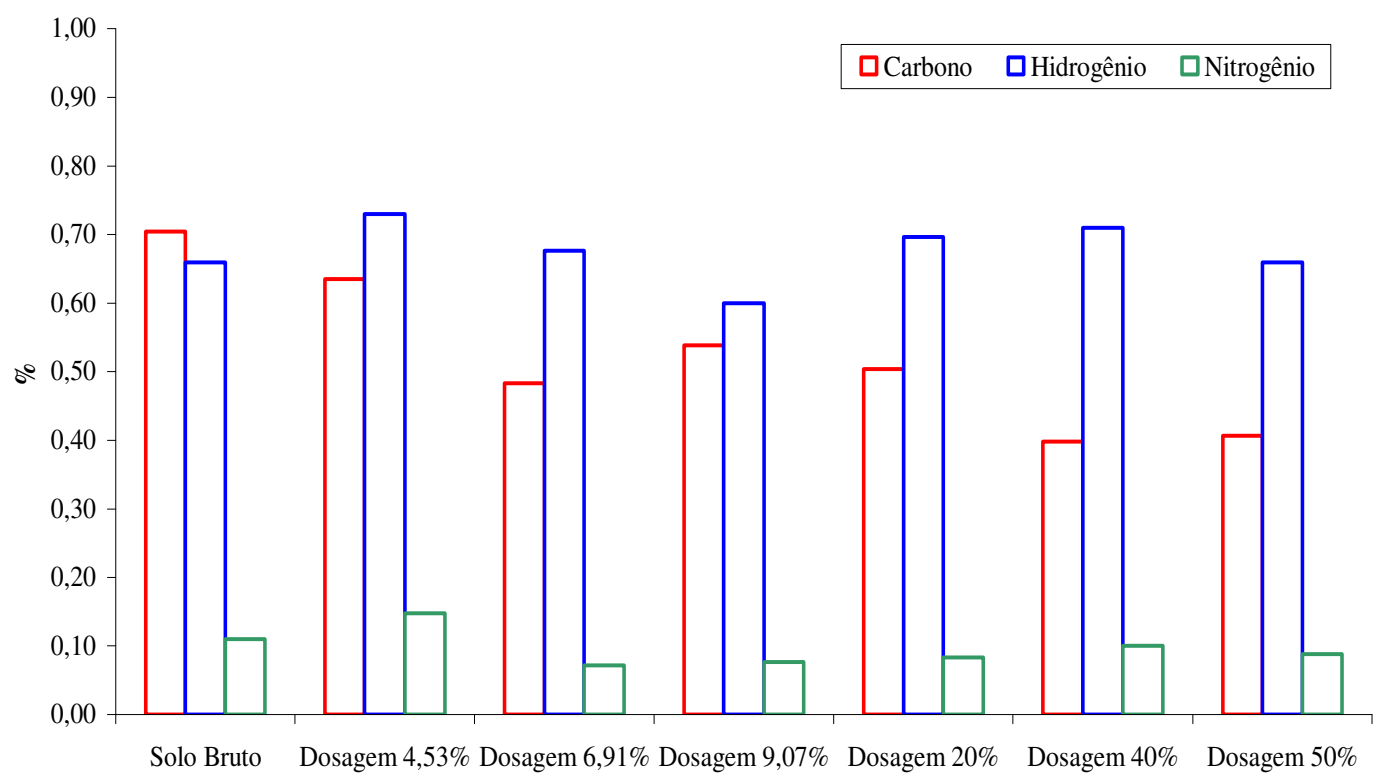

Figura 5.3.2 - Teores Médios de Carbono, Hidrogênio e Nitrogênio no Solo Bruto e na Fase Sólida da Suspensão - Ensaios de Lixiviação de Metais com Solução de Peróxido de Hidrogênio a 30\%

A tabela 5.3.2, que mostra as massas de chumbo na fase sólida das suspensões brutas e tratadas com o peróxido de hidrogênio, indica a redução das massas de chumbo na fase sólida da suspensão entre 1 e $28 \%$ em relação à massa da amostra não oxidada, dependendo da dosagem da solução de peróxido de hidrogênio a 30\% utilizada.

Tabela 5.3.2 - Massa de Pb na Fase Sólida das Suspensões não Oxidada e Tratadas com Solução de Peróxido de Hidrogênio a 30\%

\begin{tabular}{c|c|c}
\hline Dosagem $\mathbf{H}_{2} \mathbf{O}_{\mathbf{2}} \mathbf{3 0 \%}(\boldsymbol{\%})$ & $\begin{array}{c}\text { Massa de Pb na Fase } \\
\text { Sólida (mg) }\end{array}$ & $\begin{array}{c}\text { Percentual de Redução ou } \\
\text { Acréscimo em Relação à Suspensão } \\
\text { sem Acidificação (\%) }\end{array}$ \\
\hline 0,00 & 583,88 \\
4,53 & 574,13 \\
6,91 & 562,94 & - \\
\hline 9,07 & 578,50 & $-1,67$ \\
\hline 20,00 & 490,66 & $-3,59$ \\
\hline 40,00 & 446,32 & $-1,00$ \\
\hline 50,00 & 421,44 & $-15,97$ \\
\hline
\end{tabular}

Obs: (1) Massa de Pb na Fase Sólida (mg) = massa de solo seco na fase sólida da suspensão (kg) $\mathrm{x}$ teor do metal detectado na amostra da fase sólida (média dos ensaios em triplicata) (mg/kg).

As dosagens de 20, 40 e 50\% foram entre 13 e $25 \%$ mais eficientes na remoção do chumbo da fase sólida da suspensão em comparação à dosagem de 6,91\%, que produziu o maior percentual de redução entre as três primeiras utilizadas. 
A oxidação da matéria orgânica produziu a degradação dos compostos orgânicos do material contaminado e liberação do elemento chumbo da fase sólida, porém, as dosagens que produziram os maiores percentuais de remoção são muito superiores às obtidas exclusivamente para oxidação do carbono total detectado no solo.

Pode-se inferir que o chumbo e outros metais estejam associados a compostos húmicos, que são mais refratários à degradação, ou seja, menos sensíveis à alteração das condições óxido-redutoras do meio, devido às características das suas estruturas poliméricas de elevado peso molecular, formadas por compostos alifáticos e aromáticos. Estas substâncias foram identificadas na composição da matéria orgânica de solos na faixa de 35 a 92\% (HATCHER et al., 1984 apud EVANGELOU, 1998). Uma tentativa para oxidação dessas substâncias poderia ser realizada com a utilização do reagente Fenton, que seria produzido pela acidificação do meio em pH próximo a 3 (HICKWEY et al., 1995 apud DANTAS, 2005) e reação do peróxido de hidrogênio com os íons ferrosos presentes no solo. Para efeito de comparação da eficácia do processo, seriam aplicadas as dosagens do agente oxidante inicialmente utilizadas. 


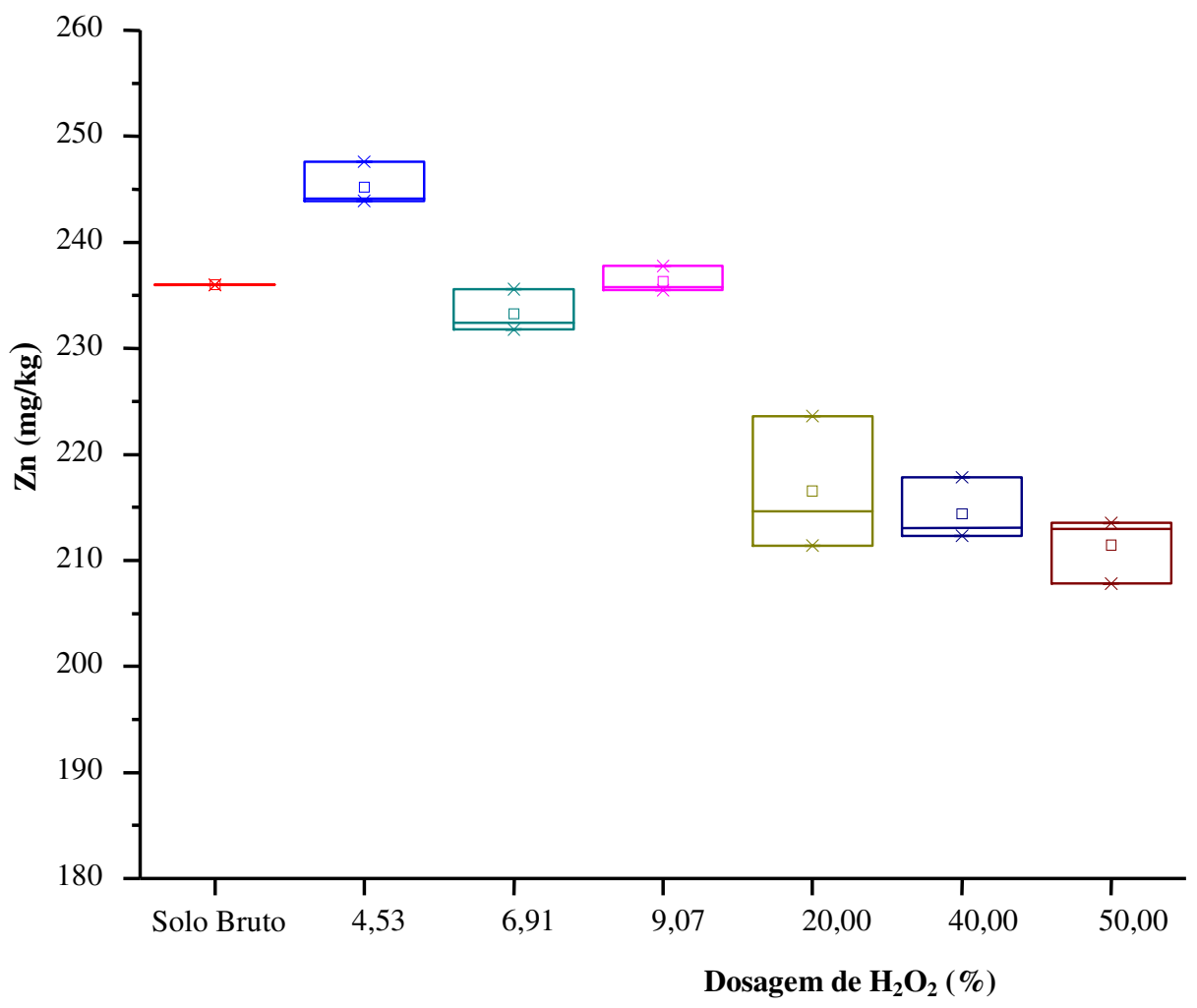

Figura 5.3.3 - Teores Mínimos, Médios e Máximos de Zn Detectados no Solo Bruto e na Fase Sólida da Suspensão - Ensaio de Lixiviação de Metais com Solução de Peróxido de Hidrogênio a 30\%

Assim como detectado para o elemento chumbo, houve redução das massas de Zn na fase sólida da suspensão entre 2 e $27 \%$ em relação à massa da amostra da suspensão não oxidada, dependendo da dosagem da solução de peróxido de hidrogênio a $30 \%$ utilizada, conforme apresentado na tabela 5.3.3.

Tabela 5.3.3 - Massa de Zn na Fase Sólida das Suspensões não Oxidada e Tratadas com Solução de Peróxido de Hidrogênio a 30\%

\begin{tabular}{c|c|c}
\hline Dosagem $\mathbf{H}_{2} \mathbf{O}_{\mathbf{2}} \mathbf{3 0 \%}(\boldsymbol{\%})$ & $\begin{array}{c}\text { Massa de Zn na Fase } \\
\text { Sólida }(\mathbf{m g})^{(\mathbf{1})}\end{array}$ & $\begin{array}{c}\text { Percentual de Redução ou } \\
\text { Acréscimo em Relação à Suspensão } \\
\text { sem Acidificação (\%) }\end{array}$ \\
\hline 0,00 & 148,01 & - \\
\hline 4,53 & 148,01 & 0,00 \\
\hline 6,91 & 145,06 & $-1,99$ \\
\hline 9,07 & 148,85 & 0,57 \\
\hline 20,00 & 127,41 & $-13,92$ \\
\hline 40,00 & 113,81 & $-23,15$ \\
\hline 50,00 & 107,73 & $-27,21$ \\
\hline
\end{tabular}

Obs: (1) Massa de Zn na Fase Sólida (mg) = massa de solo seco na fase sólida da suspensão (kg) $\mathrm{x}$ teor do metal detectado na amostra da fase sólida (média dos ensaios em triplicata) (mg/kg). 
As dosagens de 20, 40 e 50\% foram entre 12 e $26 \%$ mais eficientes na remoção do zinco da fase sólida da suspensão em comparação à dosagem de 6,91\%, que produziu o maior percentual de redução entre as três primeiras dosagens.

$\mathrm{Na}$ tabela a seguir, são listadas as concentrações de chumbo e zinco da fase líquida da suspensão, obtidas após a centrifugação da amostra durante 15 minutos a 4.000 rpm e filtração em membrana com porosidade de $0,45 \mu \mathrm{m}$. As concentrações de B detectadas foram descartadas, pois, provavelmente são advindas da lixiviação das paredes do reator de vidro e não do solo bruto, cujo valor apresentou-se abaixo do limite de detecção do método analítico.

Assim como no solo bruto, o Cd não foi detectado na fase líquida da suspensão.

Tabela 5.3.4 - Amostras da Fase Líquida da Suspensão Ensaio de Lixiviação de Metais com Solução de Peróxido de Hidrogênio a 30\%

\begin{tabular}{|c|c|c|}
\hline Dosagem $\mathrm{H}_{2} \mathrm{O}_{2} 30 \%(\%)$ & $\mathrm{Pb}(\mathrm{mg} / \mathrm{L})^{(\mathbf{1})}$ & $\mathrm{Zn}(\mathrm{mg} / \mathrm{L})^{(1)}$ \\
\hline \multirow{3}{*}{4,53} & 0,17 & $<0,01$ \\
\hline & $<0,04$ & $<0,01$ \\
\hline & 0,18 & $<0,01$ \\
\hline \multirow{3}{*}{6,91} & 0,36 & 0,08 \\
\hline & 0,36 & 0,07 \\
\hline & 0,37 & 0,08 \\
\hline \multirow{3}{*}{9,07} & 0,34 & 0,07 \\
\hline & 0,33 & 0,05 \\
\hline & 0,32 & 0,08 \\
\hline \multirow{3}{*}{20,0} & 0,25 & $<0,01$ \\
\hline & 0,25 & $<0,01$ \\
\hline & 0,19 & $<0,01$ \\
\hline \multirow{3}{*}{40,0} & 0,08 & $<0,01$ \\
\hline & 0,10 & $<0,01$ \\
\hline & 0,09 & $<0,01$ \\
\hline \multirow{3}{*}{50,0} & 0,07 & $<0,01$ \\
\hline & 0,06 & $<0,01$ \\
\hline & 0,06 & $<0,01$ \\
\hline
\end{tabular}

Obs: (1) Média dos resultados das análises realizadas em triplicata.

Nas figuras 5.3.4 e 5.3.5, são ilustradas as concentrações de $\mathrm{Pb}$ e Zn identificadas na fase líquida da suspensão, conforme apresentadas na tabela 5.3.4. 


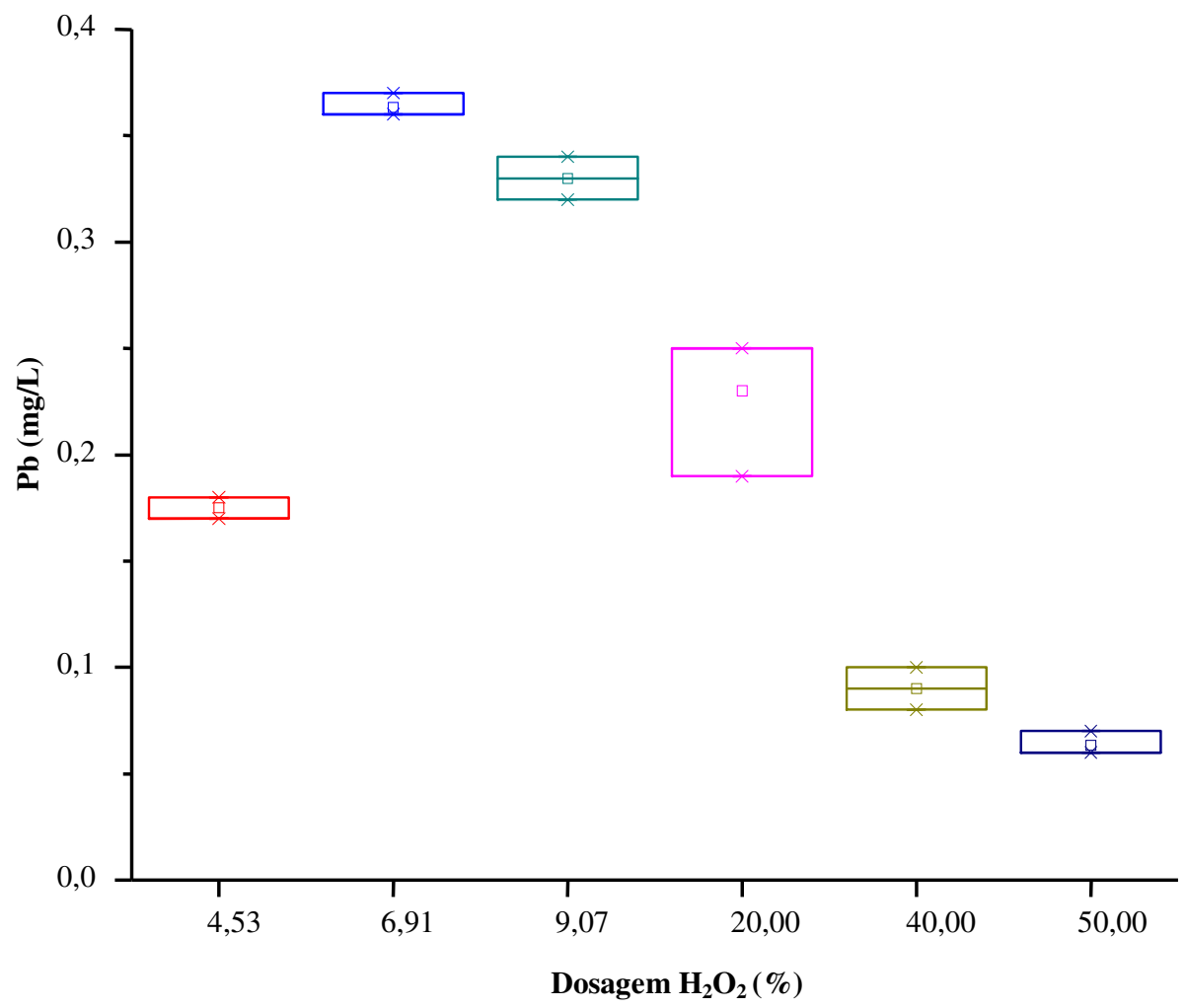

Figura 5.3.4 - Concentrações Mínimas, Médias e Máximas de Pb Detectadas na Fase Líquida da Suspensão - Ensaio de Lixiviação de Metais com Solução de Peróxido de Hidrogênio a 30\%

A redução dos teores de $\mathrm{Pb}$ da fase sólida da suspensão não foi acompanhada do aumento da concentração deste elemento na fase líquida, com o acréscimo da dosagem da solução de peróxido. Provavelmente, a massa de chumbo lixiviada da fase sólida foi transferida para os sólidos em suspensão, que ficaram retidos na membrana de porosidade $0,45 \mu \mathrm{m}$, como também, devido à reação altamente exotérmica, desencadeada a partir da adição da solução de peróxido de hidrogênio à suspensão de material contaminado, com ocorrência de grande liberação de vapores e pequena perda de massa, o chumbo dissolvido na fase líquida pode ter sido perdido.

$\mathrm{Na}$ tabela a seguir são apresentadas as massas de chumbo nas suspensões não oxidada e tratadas com a solução de peróxido de hidrogênio a $30 \%$. 
巳̊

0
0
$\circ$
0
0
0
0
0
0
0
0
0
0
0
0
0
0
0
10
$\Xi$
0
0
0
0
0
0

胥$$
\text { 意 }
$$

홍

용

.

紊

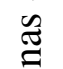

D

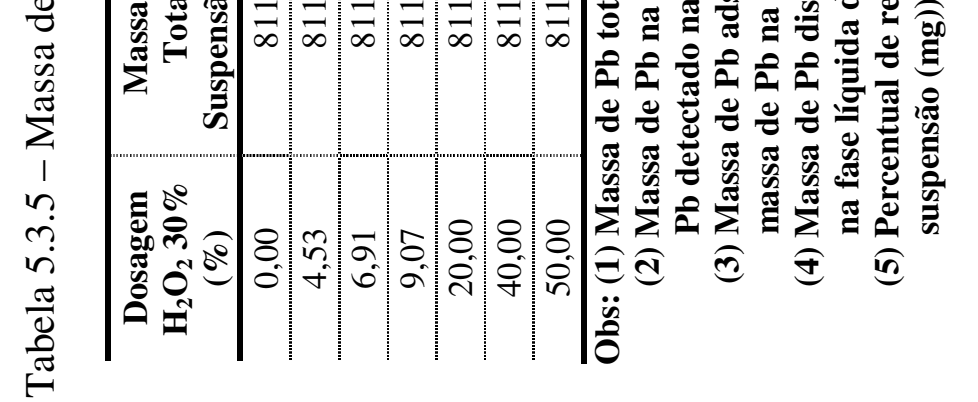

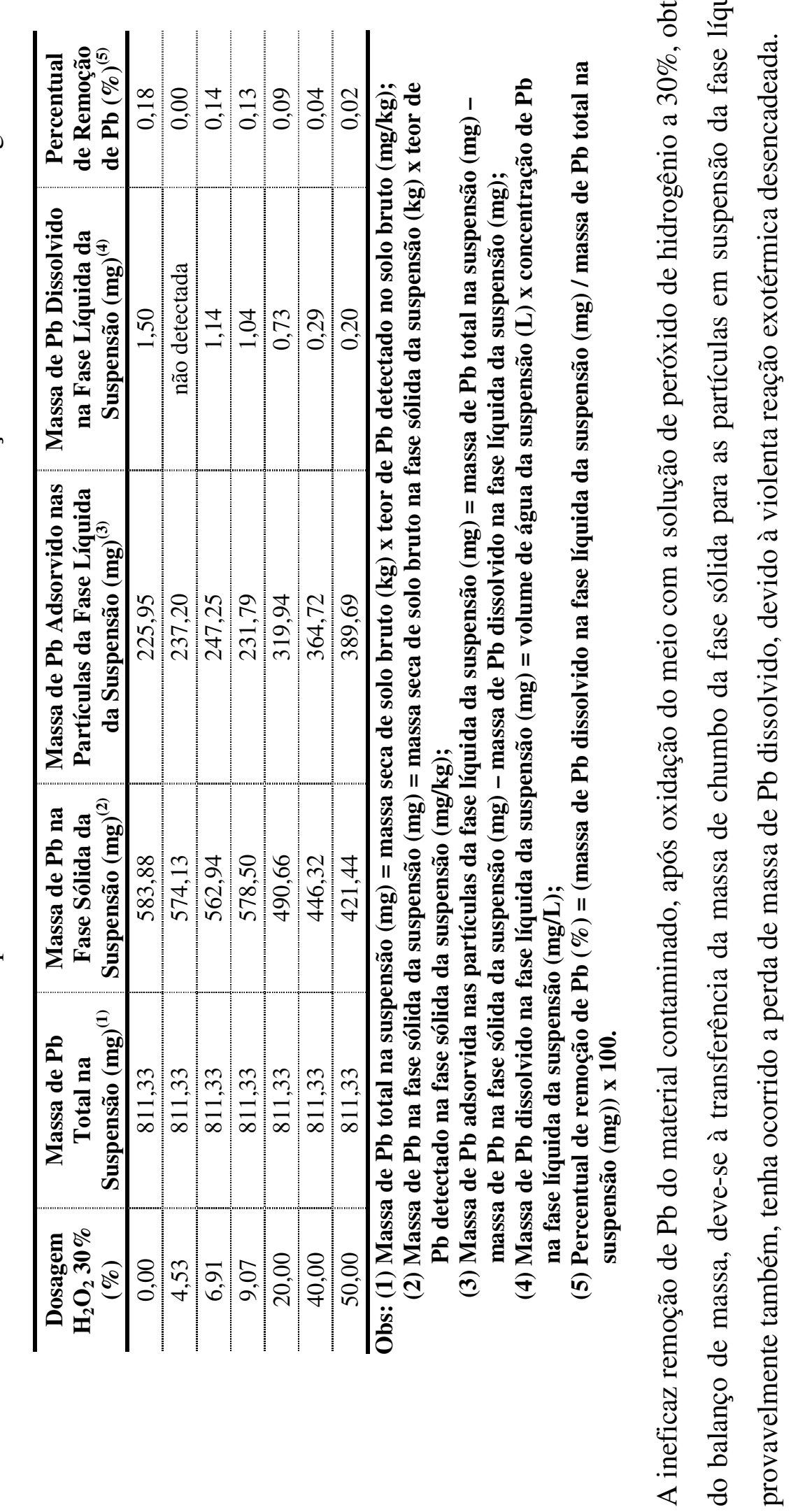




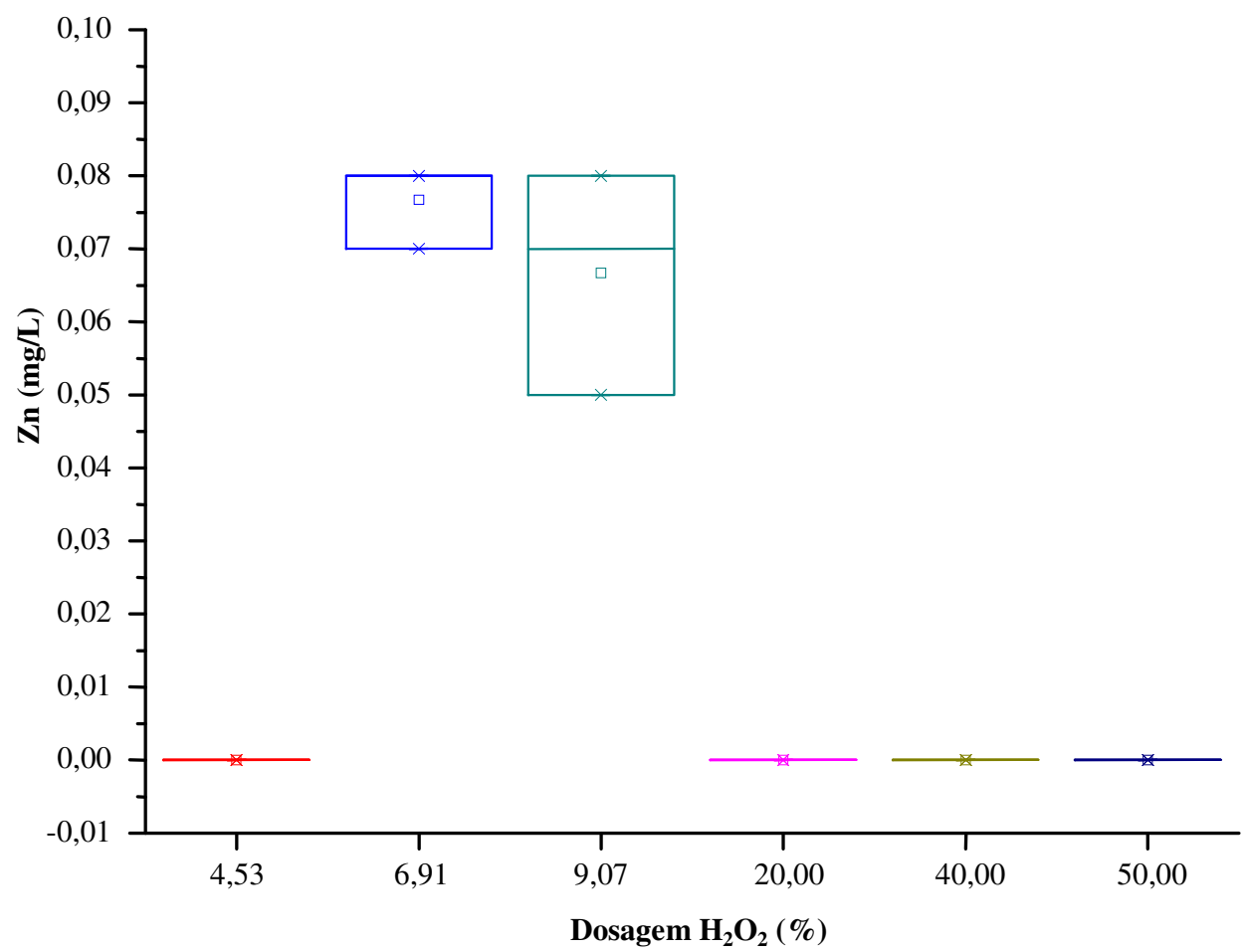

Figura 5.3.5 - Concentração de Zn na Fase Líquida da Suspensão Ensaio de Lixiviação com Solução de Peróxido de Hidrogênio a 30\%

Como observado para o elemento chumbo, a redução dos teores de $\mathrm{Zn}$ da fase sólida da suspensão não foi acompanhada do aumento da concentração na fase líquida, com o acréscimo da dosagem da solução de peróxido, tendo sido a massa de zinco da fase sólida, transferida para os sólidos em suspensão que ficaram retidos na membrana de porosidade $0,45 \mu \mathrm{m}$ ou reduzida pela perda parcial de massa da suspensão de solo.

Na tabela a seguir, são apresentadas as massas de zinco nas suspensões não oxidada e tratadas com a solução de peróxido de hidrogênio a $30 \%$. 


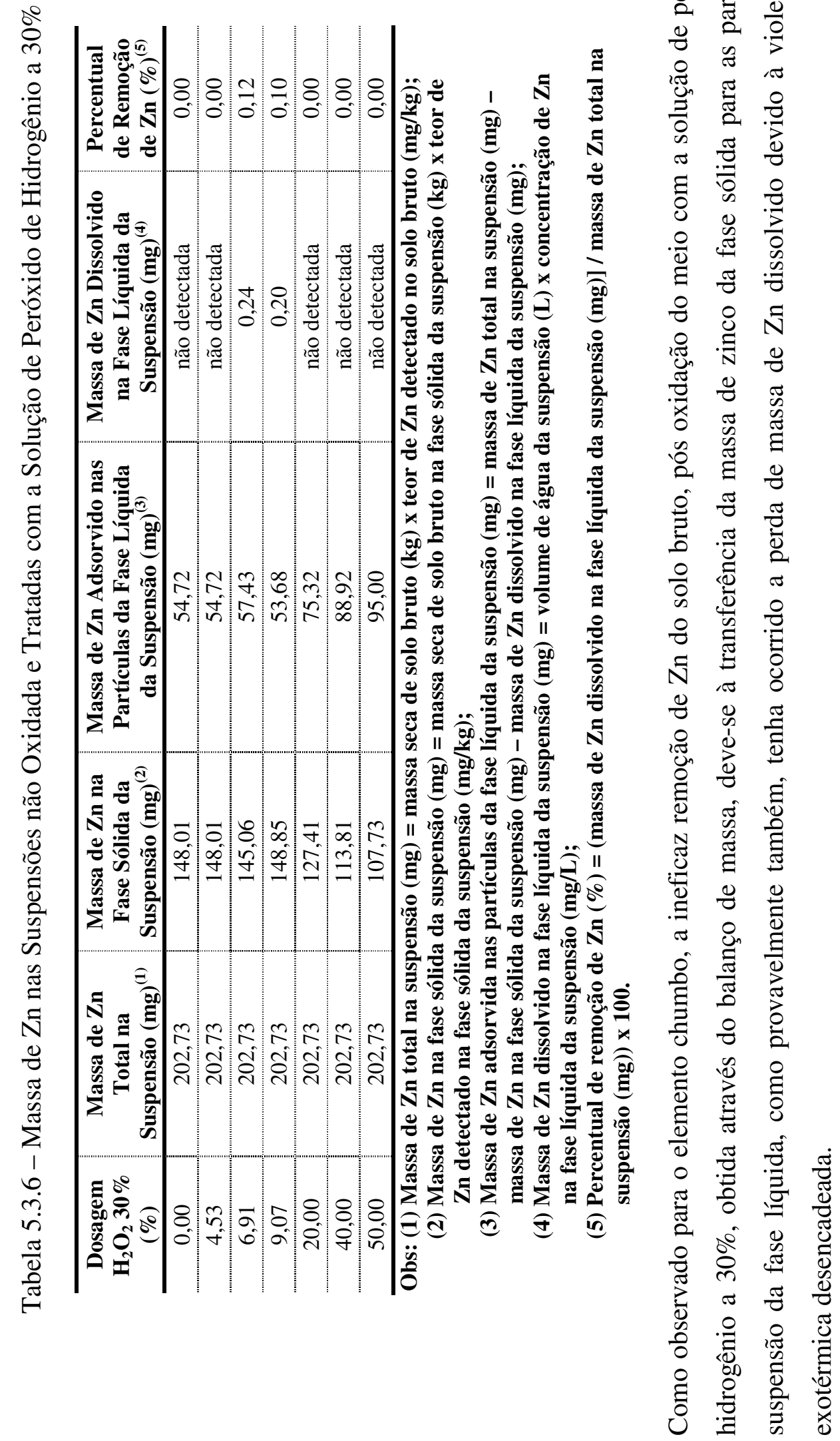




\subsection{Resultados obtidos no ensaio de lixiviação dos metais com a utilização da solução de ácido clorídrico $0,1 \mathrm{M}$}

Conforme procedimento da etapa de abertura leve da extração seqüencial de metais pesados, proposto por KERSTEN e FÖRSTNER (1990) e BEVILACQUA e LICHTIG (2004), foram realizados em triplicata os ensaios de lixiviação de B, Cd, $\mathrm{Pb}$ e $\mathrm{Zn}$ da matriz sólida.

As concentrações dos metais detectados na fase líquida (lixiviado) foram comparadas àquelas resultantes nas amostras da fase líquida da suspensão em pH 8 (material contaminado), coletadas no ensaio de lixiviação com ácido sulfúrico concentrado, sendo os valores médios das concentrações detectadas por reator, nas determinações químicas realizadas em triplicata, relacionados na tabela 5.4.1.

As concentrações de $\mathrm{B}$ detectadas na fase líquida foram descartadas, pois, provavelmente são advindas da lixiviação das paredes do reator de vidro e não do material contaminado, cujo valor apresentou-se abaixo do limite de detecção do método analítico.

Assim como no material contaminado, o $\mathrm{Cd}$ não foi detectado na fase líquida da suspensão.

Tabela 5.4.1 - Concentrações de $\mathrm{Pb}$ e Zn das Amostras do Lixiviado Ensaio de Lixiviação de Metais com Solução de Ácido Clorídrico 0,1 M

\begin{tabular}{|c|c|c|c|}
\hline \multicolumn{2}{|l|}{ Amostra } & $\mathbf{P b}(\mathrm{mg} / \mathrm{L})^{(1)}$ & $\mathrm{Zn}(\mathrm{mg} / \mathrm{L})^{(1)}$ \\
\hline \multirow{3}{*}{ pH 8 (sem acidificação) } & $\mathrm{R} 1$ & 0,420 & 0,062 \\
\hline & $\mathrm{R} 2$ & 0,469 & $<0,020$ \\
\hline & R3 & 0,540 & $<0,020$ \\
\hline \multirow{3}{*}{ Ensaio 1} & R1 & 41,305 & 7,147 \\
\hline & $\mathrm{R} 2$ & 40,350 & 6,560 \\
\hline & $\mathrm{R} 3$ & 45,485 & 9,262 \\
\hline \multirow{3}{*}{ Ensaio 2} & $\mathrm{R} 1$ & 33,287 & 5,870 \\
\hline & $\mathrm{R} 2$ & 32,927 & 5,766 \\
\hline & $\mathrm{R} 3$ & 34,474 & 5,804 \\
\hline \multirow{3}{*}{ Ensaio 3} & $\mathrm{R} 1$ & 46,440 & 5,339 \\
\hline & $\mathrm{R} 2$ & 32,179 & 4,959 \\
\hline & R3 & 33,537 & 5,603 \\
\hline
\end{tabular}

Obs: (1) Média dos resultados das análises realizadas em triplicata - Método 6010B (USEPA, 1996b).

A dosagem da solução de ácido clorídrico $0,1 \mathrm{M}$, utilizada no ensaio, produziu o consumo de 195,88 g de $\mathrm{HCl}$ concentrado por quilo de solo seco. 
Nas figuras a seguir, são ilustradas as concentrações mínimas, médias e máximas de

$\mathrm{Pb}$ e $\mathrm{Zn}$, detectadas no lixiviado, após adição da solução de ácido clorídrico 0,1 M.

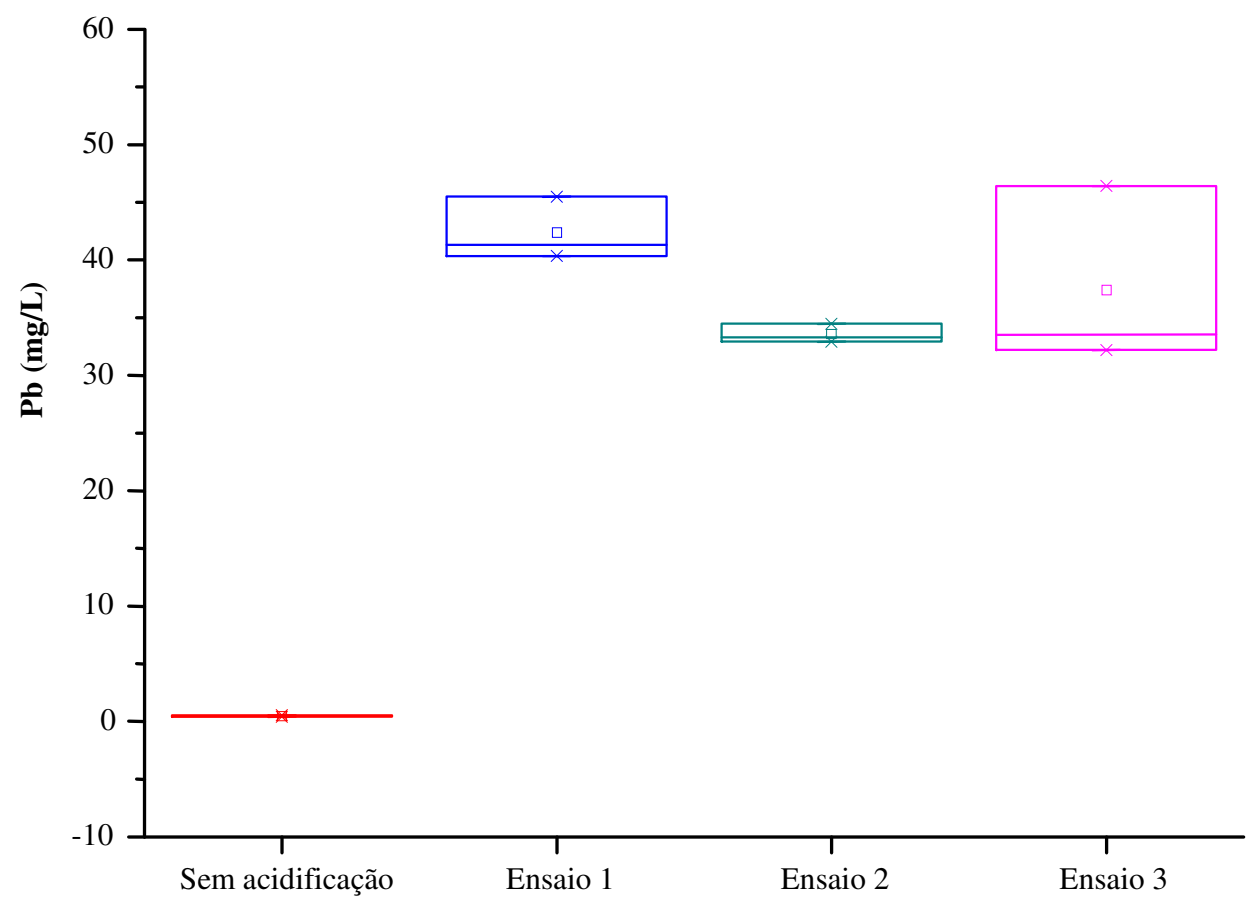

Figura 5.4.1 - Concentrações Mínimas, Médias e Máximas de Pb Detectadas no Lixiviado Ensaio de Lixiviação de Metais com Solução de Ácido Clorídrico 0,1 M 


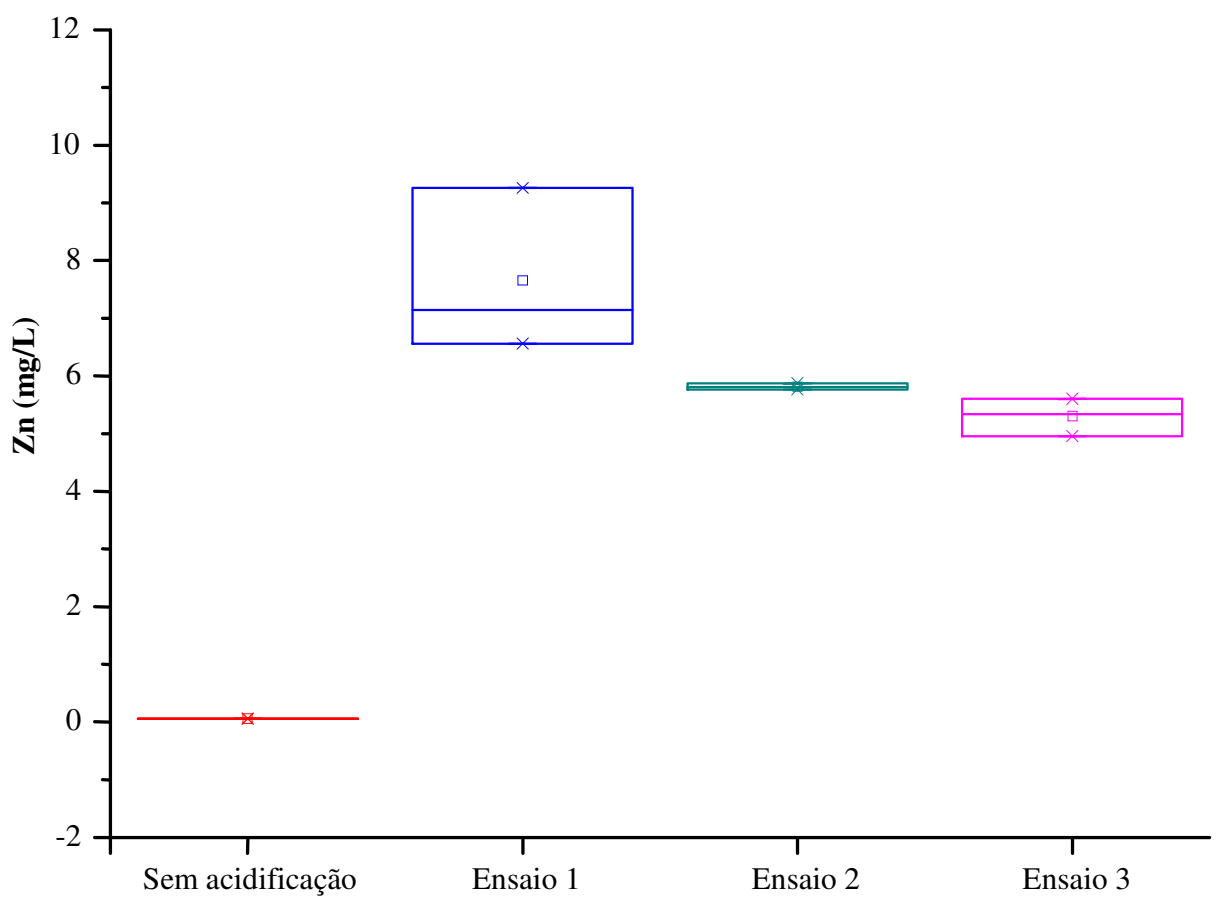

Figura 5.4.2 - Concentrações Mínimas, Médias e Máximas de Zn Detectadas no Lixiviado Ensaio de Lixiviação de Metais com Solução de Ácido Clorídrico 0,1 M

Nas tabelas, a seguir, são apresentadas as massas totais de chumbo e zinco na suspensão e nas fases sólida e líquida não acidificada e tratada com $\mathrm{HCl}$. 
Tabela 5.4.2 - Massa de Pb nas Suspensões não Acidificada e Tratadas com Solução de Ácido Clorídrico 0,1 M

\begin{tabular}{c|c|c|c|c}
\hline Amostra & $\begin{array}{c}\text { Massa de Pb } \\
\text { Total na } \\
\text { Suspensão (mg) }\end{array}$ & $\begin{array}{c}\text { Massa de Pb } \\
\text { Dissolvido na Fase } \\
\text { Líquida da } \\
\text { Suspensão (mg) }\end{array}$ & $\begin{array}{c}\text { Massa de Pb } \\
\text { Remanescente na } \\
\text { Fase Sólida da } \\
\text { Suspensão (mg) }\end{array}$ & $\begin{array}{c}\text { Percentual de } \\
\text { Remoção de } \\
\text { Pb (\%) }\end{array}$ \\
\hline $\begin{array}{c}\text { Não } \\
\text { acidificada }\end{array}$ & 811,33 & 809,83 & 0,18 \\
\hline $\begin{array}{c}\text { HCl } \\
\text { Ensaio 1 }\end{array}$ & 811,33 & 1,50 & 678,21 & 16,41 \\
\hline $\begin{array}{c}\text { HCl } \\
\text { Ensaio 2 }\end{array}$ & 811,33 & 105,42 & 705,91 & 12,99 \\
$\begin{array}{c}\text { HCl } \\
\text { Ensaio 3 }\end{array}$ & 811,33 & 117,43 & 693,9 & 14,47 \\
$\begin{array}{c}\text { HCl } \\
\text { Média dos } \\
\text { Ensaios }\end{array}$ & 811,33 & 118,66 & 692,67 & 14,62 \\
\hline
\end{tabular}

Obs: (1) Massa de Pb total na suspensão (mg) = massa seca de solo bruto (kg) x teor de $\mathrm{Pb}$ do solo bruto (mg/kg);

(2) Massa de $\mathrm{Pb}$ dissolvido na fase líquida da suspensão $(\mathrm{mg})=$ volume de água da suspensão ( $L$ ) x concentração de $\mathbf{P b}$ na fase líquida da suspensão $(\mathrm{mg} / \mathrm{L})$;

(3) Massa de $\mathrm{Pb}$ remanescente na fase sólida da suspensão $(\mathrm{mg})=$ massa de $\mathrm{Pb}$ total na suspensão (mg) - massa de $\mathbf{P b}$ dissolvido na fase líquida da suspensão (mg)

(4) Percentual de remoção de $\mathrm{Pb}(\%)=\{[$ massa de $\mathrm{Pb}$ total na suspensão $(\mathrm{mg})$ - massa de $\mathrm{Pb}$ remanescente na fase sólida da suspensão (mg)] / massa de Pb total na suspensão (mg)\} x 100 
Tabela 5.4.3 - Massa de Zn nas Suspensões não Acidificada e Tratadas com Solução de Ácido Clorídrico 0,1 M

\begin{tabular}{|c|c|c|c|c|}
\hline Amostra & $\begin{array}{c}\text { Massa de Zn } \\
\text { Total na } \\
\text { Suspensão }(\mathbf{m g})^{(\mathbf{1})}\end{array}$ & $\begin{array}{c}\text { Massa de } \mathbf{Z n} \\
\text { Dissolvido na Fase } \\
\text { Líquida da } \\
\text { Suspensão }(\mathbf{m g})^{(2)}\end{array}$ & $\begin{array}{c}\text { Massa de } \mathbf{Z n} \\
\text { Remanescente na } \\
\text { Fase Sólida da } \\
\text { Suspensão }(\mathbf{m g})^{(\mathbf{3})}\end{array}$ & $\begin{array}{c}\text { Percentual de } \\
\text { Remoção de } \\
\text { Zn }(\%)^{(4)}\end{array}$ \\
\hline $\begin{array}{c}\text { Não } \\
\text { acidificada }\end{array}$ & 202,73 & não detectada & 202,73 & 0,00 \\
\hline $\begin{array}{c}\mathrm{HCl} \\
\text { Ensaio } 1\end{array}$ & 202,73 & 24,05 & 178,68 & 11,86 \\
\hline $\begin{array}{c}\mathrm{HCl} \\
\text { Ensaio } 2\end{array}$ & 202,73 & 18,26 & 184,47 & 9,01 \\
\hline $\begin{array}{c}\mathrm{HCl} \\
\text { Ensaio } 3\end{array}$ & 202,73 & 16,65 & 186,08 & 8,21 \\
\hline $\begin{array}{l}\mathrm{HCl} \\
\text { Média dos } \\
\text { Ensaios }\end{array}$ & 202,73 & 19,65 & 183,08 & 9,69 \\
\hline
\end{tabular}

Obs: (1) Massa de Zn total na suspensão (mg) = massa seca de solo bruto $(\mathrm{kg}) \mathrm{x}$ teor de $\mathrm{Zn}$ detectado no solo bruto $(\mathrm{mg} / \mathrm{kg})$;

(2) Massa de Zn dissolvido na fase líquida da suspensão $(\mathrm{mg})=$ volume de água da suspensão $(L) x$ concentração de $Z n$ na fase líquida da suspensão $(\mathrm{mg} / \mathrm{L})$;

(3) Massa de Zn remanescente na fase sólida da suspensão $(\mathrm{mg})$ = massa de $\mathrm{Zn}$ total na suspensão (mg) - massa de Zn dissolvido na fase líquida da suspensão $(\mathbf{m g})$;

(4) Percentual de remoção de $\mathrm{Zn}(\%)=\{[$ massa de $\mathrm{Zn}$ total na suspensão $(\mathrm{mg})$ - massa de Zn remanescente na fase sólida da suspensão $(\mathrm{mg})]$ / massa de Zn total na suspensão (mg)\} x 100

O zinco e o chumbo podem ser encontrados nos solos como cátions divalentes solúveis na fase aquosa, adsorvidos aos óxidos e hidróxidos de ferro e alumínio, ligados à matéria orgânica ou como óxidos insolúveis.

Os resultados mostrados na tabela 5.4.1 indicam que a adição de água no solo natural ocasionou uma liberação de chumbo e zinco, atingindo concentrações de até 0,54 $\mathrm{mgPb} / \mathrm{L}$ e 0,062 mgZn/L na fase aquosa. Com a adição de solução de $\mathrm{HCl}$ 0,1 M, estas concentrações aumentaram significativamente, induzindo à conclusão que houve uma solubilização dos metais com a adição do ácido e posteriormente, a formação de cloretos metálicos, que são solúveis em água. Entretanto, observando as tabelas 5.4.2 e 5.4.3, nota-se que as remoções médias de zinco e de chumbo foram de $9,7 \%$ e $14,6 \%$, respectivamente.

A solubilização dos metais presentes no material contaminado, com a adição de solução de ácido clorídrico, obtida nesta pesquisa, foi atestada por diversos pesquisadores, sendo citados alguns nos parágrafos a seguir. 
Em 1989, a Canadian Council of Ministers of Environment estabeleceu o National Contaminated Sites Remediation Program (NCSRP), que tinha por finalidade obter dados mais consistentes de tecnologias de remediação, a fim de aplicá-las nos locais mais contaminados do Canadá. Dentro deste Programa, foi realizado um estudo piloto em uma área contaminada, localizada em Saint John, New Brunswick (CANADÁ, 1993). Fluido dielétrico contendo PCBs e metais pesados ( $\mathrm{Cd}, \mathrm{Cu}, \mathrm{Pb}$ e $\mathrm{Zn)} \mathrm{contaminaram} \mathrm{o} \mathrm{solo.} \mathrm{A} \mathrm{lavagem} \mathrm{com} \mathrm{ácido} \mathrm{clorídrico,} \mathrm{em} \mathrm{pH}$ 2,0, resultou na redução dos teores de chumbo de $22.800 \mathrm{mg} / \mathrm{kg}$ a $8.420 \mathrm{mg} / \mathrm{kg}(63 \%)$ e de zinco de $4130 \mathrm{mg} / \mathrm{kg}$ a $2.700 \mathrm{mg} / \mathrm{kg}$ (35\%), após tempo de contato de 2 horas.

A EPA (ESTADOS UNIDOS, 1994) realizou um trabalho, cujo objetivo era determinar a eficácia e a viabilidade econômica da lavagem ácida de solos contaminados na redução das concentrações e da lixiviabilidade de metais pesados. Cinco tipos de solo foram testados. Eles continham elevados teores de arsênio, cádmio, cromo, cobre, chumbo, níquel e zinco. Os teores de zinco variaram de 239 a $14.00 \mathrm{mg} / \mathrm{kg}$ e os de chumbo, de 390 a $29.200 \mathrm{mg} / \mathrm{kg}$. Os resultados mostraram que a lavagem ácida era capaz de tratar todos os tipos de solo estudados, obtendo remoções de zinco e chumbo de 18 a $96 \%$ e 34 a 95\%, respectivamente, em pH igual a 2,0. Entretanto, as concentrações de chumbo no lixiviado do solo tratado não atendiam aos limites legais.

Segundo ALLOWAY (1995), a efetiva redução dos teores de chumbo de um solo pode ser obtida com a diminuição do pH para 2,5-3,0, através da adição de soluções de ácido clorídrico ou de cloreto férrico, sendo que a primeira produz a solubilização e a segunda, a precipitação do elemento.

REED, CARRIERI e MOORE (1996) investigaram a remediação de um solo arenoso contaminado artificialmente com chumbo, pela lavagem com solução de $\mathrm{HCl}$ 0,1 M, EDTA $0,01 \mathrm{M}$ e cloreto de cálcio $1 \mathrm{M}$, em ensaio de laboratório, em coluna operada continuamente. Obtiveram eficiência de remoção de $85 \%$ de chumbo (teor inicial de 500 a $600 \mathrm{mg} / \mathrm{kg}$ ), mas este tratamento não reduziu as concentrações ao nível de "background" (25 mg/kg).

As baixas remoções dos dois metais, obtidas no presente trabalho, provavelmente, devem-se à utilização de uma solução fraca de ácido clorídrico, com apenas um ciclo de extração, num solo argiloso. Os resultados corroboram com os obtidos por 
PICHTEL e PICHTEL (1997), que compararam a lavagem de solo contaminado de uma unidade industrial abandonada, que continha $4.940 \mathrm{mg} / \mathrm{kg}$ de cromo total e $1.300 \mathrm{mg} / \mathrm{kg}$ de chumbo, $\mathrm{pH}$ igual a 10,3, com soluções de EDTA $(0,1 ; 0,01 ; 0,001 \mathrm{e}$ 0,0001M), ácido nitriloacético (0,1 e 0,001 M), dodecil sulfato de sódio (0,1 e 0,001 M) e ácido clorídrico $(0,25$ a $8 \%$ v/v $)$. A lavagem com solução de ácido clorídrico a $1 \%$ resultou numa remoção de $14,7 \%$ de cromo e $3,8 \%$ de chumbo.

STEELE e PICHTEL (1998) avaliaram o uso de EDTA, ácido n-2-acetamido-iminodi-acético, ácido piridina-2,6-dicarboxílico e ácido clorídrico como soluções de lavagem de solo contaminado, que continha $65.200 \mathrm{mg} / \mathrm{kg}$ de chumbo e $52 \mathrm{mg} / \mathrm{kg}$ de cádmio. O solo era submetido a três ciclos de extração de uma hora com cada um dos agentes de lixiviação. Os pesquisadores obtiveram remoção de 54\% de Pb com ácido clorídrico. O teor de chumbo no solo tratado com o ácido não estava abaixo do limite estabelecido pela legislação $(1.000 \mathrm{mg} / \mathrm{kg})$.

PICHTEL et al. (2001) avaliaram a eficiência de extração de chumbo com EDTA e soluções de ácido piridina-2,6-dicarboxílico 0,0225 M e de ácido clorídrico 0,1M e 1 M, de um solo silto-argiloso, de sedimentos e de uma areia artificialmente contaminados com sulfato de chumbo, bem como de um solo contaminado de uma indústria de reciclagem de baterias. Os autores conseguiram uma eficiência de remoção de até $30 \%$ de chumbo no solo contaminado e de 30 a $51 \%$ nos solos artificialmente contaminados, utilizando solução de $\mathrm{HCl}$ 1M. 


\section{CONCLUSÕES}

A partir dos resultados obtidos no presente trabalho, conclui-se:

- Ao contrário da caracterização do material contaminado da Região dos Lagos de Santa Gertrudes (SP), realizada em pesquisas anteriores, foram observados teores de boro e cádmio abaixo do limite de detecção do método analítico $(<0,03$ $\mathrm{mgB} / \mathrm{kg}$ e $<0,003 \mathrm{mgCd} / \mathrm{kg}$ ). Desta forma, estes elementos não foram avaliados em nenhum dos ensaios realizados;

- A amostra composta de solo contaminado, coletada na área da indústria cerâmica desativada Poliglass, apresentou 945 mg/kg de $\mathrm{Pb}$ e 236 mg/kg de Zn;

- A lixiviação do $\mathrm{Pb}$ com ácido sulfúrico não se mostrou eficiente, pois foi produzido sulfato de chumbo, cuja solubilidade em água é baixa. Por esta razão, a massa de chumbo do solo tratado com o ácido aumentou com o decréscimo de $\mathrm{pH}$;

- Obteve-se remoção de Zn, através da lavagem do solo com ácido sulfúrico, de até $50 \%$, sendo o teor remanescente igual a $117 \mathrm{mg} / \mathrm{kg}$, valor abaixo do limite de prevenção determinado pelo órgão de controle ambiental do Estado de São Paulo, que indica que houve alteração das condições naturais do solo, porém a adoção de medidas corretivas não é necessária.

- O consumo de ácido sulfúrico concentrado por quilo de solo tratado foi de 12,4 g.

- O material contaminado apresentou teor de carbono de 0,4 a 0,8\%. Provavelmente, este teor refere-se ao material húmico, que apresenta refratabilidade à oxidação química. Desta forma, somente com dosagens de $40 \mathrm{e}$ $50 \%$ (massa/massa) de peróxido de hidrogênio, foram obtidas remoções de 43 e $41 \%$ de carbono, respectivamente.

- A oxidação da suspensão com peróxido de hidrogênio foi ineficaz na remoção de $\mathrm{Pb}$ e $\mathrm{Zn}$, devido à transferência da massa dos metais da fase sólida para os sólidos em suspensão da fase líquida. A quantidade da solução de peróxido de hidrogênio a 30\% utilizada para tratamento do solo, conforme dosagens, esteve entre 151 $\mathrm{gH}_{2} \mathrm{O}_{2} / \mathrm{kg}$ solo seco (dosagem 4,53\%) e $1.666 \mathrm{~g} \mathrm{H}_{2} \mathrm{O}_{2} / \mathrm{kg}$ solo seco (dosagem $50 \%)$.

- A reação altamente exotérmica desencadeada após a adição da solução de peróxido de hidrogênio à suspensão de solo produziu a grande liberação de 
vapores e pequena perda de massa, o que prejudicou a determinação da quantidade de massa dissolvida de $\mathrm{Pb}$ e $\mathrm{Zn}$;

- A lixiviação dos metais do solo produzida pela solução de ácido clorídrico $0,1 \mathrm{M}$ reduziu os teores de $\mathrm{Pb}$ e $\mathrm{Zn}$ em 15 e 10\%, respectivamente, tendo sido consumido $196 \mathrm{~g}$ de $\mathrm{HCl}$ por quilo de solo tratado. Os teores remanescentes de chumbo e zinco, próximos de $806 \mathrm{mg} \mathrm{Pb/kg} \mathrm{e} 213 \mathrm{mg} \mathrm{Zn/kg}$, estão abaixo do limite estabelecido como valor de intervenção em áreas industriais, o que reclassifica a área de estudo como não contaminada.

- O solo contaminado da Região dos Lagos de Santa Gertrudes pode ser remediado pela simples lavagem com ácido clorídrico e posterior precipitação dos metais, uma vez que foi a tecnologia mais eficiente dentre as estudadas. 


\section{RECOMENDAÇÕES PARA FUTURAS PESQUISAS}

Recomenda-se a realização das seguintes pesquisas:

- Verificar a possibilidade de separação física das frações do material contaminado, seguida da lixiviação somente daquelas que necessitarem deste tratamento;

- Avaliar a lixiviação do zinco e chumbo do material contaminado com ácidos orgânicos;

- Investigar a lixiviação do zinco e chumbo do material contaminado com ácido clorídrico até pH igual a 2,0, com múltiplas extrações;

- Avaliar a lixiviação do zinco e chumbo do material contaminado pela lavagem com agentes complexantes;

- Averiguar o tratamento do material contaminado com a combinação de agentes lixiviantes;

- Avaliar a remoção de metais pesados do material contaminado pela fitorremediação. 


\section{REFERÊNCIAS BIBLIOGRÁFICAS}

ACEVEDO, F. Present and Future of Bioleaching in Developing Countries. EJB Electronic Journal of Biotechnology, Universidade Católica de Valparaíso, Chile, volume 5, nº 2, pág. 196-199, agosto 2002.

Acidithiobacillus ferrooxidans. Acesso on line em 12/05/2004: http://www.mines.edu/fs_home/jhoran/ch126/thiobaci.htm.

ALLOWAY, B. J. Heavy Metals in Soils. Second Edition, pág. 3-57; 206-223; 284305, Blackie Academic \& Professional, 1995.

ANDREW HONG, P. K.; LI, C.; BANERJI, S. K.; REGMI, T. Extraction, Recovery and Biostability of EDTA for Remediation of Heavy Metal Contaminated Soil. Journal of Soil Remediation, 8(1), pág. 81-103, 1999.

BRASIL. ASSOCIAÇÃO BRASILEIRA DE NORMAS TÉCNICAS (ABNT). Solo - Análise Granulométrica - NBR 7181, 1984.

BASTA, N. T.; McGOWEN, S. L. Evaluation of Chemical Immobilization Treatments for Reducing Heavy Metal Transport in a Smelter-Contaminated Soil. Environmental Pollution, 127, pág. 73-82, 2003.

BEVILACQUA, J. E.; LICHTIG, J. Caracterização Biogeoquímica de Sedimentos do Rio Tietê (Pirapora a Barra Bonita). Instituto de Química da Universidade de São Paulo, pág. 1-24, 2004.

BOURG, A. C. M. Speciation of Heavy Metals in Soils and Groundwater and Implications for Their Natural and Provoked Mobility. In: SALOMONS, W.; FÖRSTNER, U.; MADER, P. (Eds.). Heavy Metals Problems and Solutions, pág. 19-31. Springer-Verlag Berlin Heidelberg, 1995.

BROOKINS, D. G. EH-pH Diagrams for Geochemistry, pág. 42-45; 54-55. Springer-Verlag Berlin Heidelberg, 1988.

CÂMARA, V. M.; SIlVA, A. P.; MACIEL, M. V.; PIVETTA, F.; PEREZ, M. A. Mercury Exposure and Health Effects Among Urban Residents due to Gold 
Commercialization in Poconé, MT, Brazil. Tecnologia Ambiental, MCT, CNPq, CETEM, 1997.

CANADÁ. The National Contaminated Sites Remediation Program. Development and Demostration of Site Remediation Technology Program. Evaluation of Soil Washing and Bioslurry Reactor Treatments for PCB-Heavy Metal Contaminated Soils Washburn\&Gillis Associates Ltd. Project Summary, 1993. Acesso on line em 01/06/2006: http://www.qc.ec.gc.ca/dpe/Publication/Detalc/14_e.htm.

CETESB (COMPANHIA DE TECNOLOGIA DE SANEAMENTO AMBIENTAL). Decisão de Diretoria n ${ }^{0}$ 195-2005-E, de 23 de novembro de 2005.

CETESB (COMPANHIA DE TECNOLOGIA DE SANEAMENTO AMBIENTAL); GTZ (DEUTSCHE GESELLSCHAFT TECHNISCHE ZUSAMMENARBEIT). Manual de Gerenciamento de Áreas Contaminadas. Projeto de Cooperação Técnica Brasil-Alemanha, $2^{\mathrm{a}}$ edição, 2001.

CHINTHAMREDDY, S.; REDDY, K. R. Oxidation and Mobility of Trivalent Chromium in Manganese-Enriched Clays During Electrokinetic Remediation. Journal of Soil Contamination, 8(2), pág. 197-216, 1999.

DANTAS, T. L. P. Decomposição de Peróxido de Hidrogênio em um Catalisador Híbrido e Oxidação Avançada de Efluente Têxtil por Reagente Fenton Modificado. 2005. 106p. Dissertação (Mestrado), Centro Tecnológico da Universidade Federal de Santa Catarina. Florianópolis, 2005.

DIAS, L. E.; GRIFFITH, J. J. Conceituação e Caracterização de Áreas Degradadas. In: DIAS, L. E.; MELLO, J. W. V. Recuperação de Áreas Degradadas. Departamento de Solos. Universidade Federal de Viçosa. Sociedade Brasileira de Recuperação de Áreas Degradadas, 1998.

Di PALMA, L; FERRANTELLI, P.; MERLI, C.; BIANCIFIORI, F. Recovery of EDTA and Metal Precipitation from Soil Flushing Solutions. Journal of Hazardous Materials, B(103), pág. 153-168, 2003. 
EEA (EUROPEAN ENVIRONMENT AGENCY). Management of Contaminated Sites in Western Europe, 2.000. (Topic Report n 13, 1999).

ESTADOS UNIDOS. ENVIRONMENTAL PROTECTION AGENCY. Office of Research and Development. Acid Extraction Treatment System for Treatment of Metal Contaminated Soils. Cincinnati, Ohio: EPA. EPA/540/R-94/513. 1994

EVAnGEloU, V. P. Environmental Soil and Water Chemistry: Principles and Applications. Willey, New York, pág. 100-166; 229-271, 1988.

GEO-INF. Avaliação de Área Contaminada para Fins de Cubagem, em Santa Gertrudes, SP. Relatório Técnico GEO-INF 025/2002.

GWRTAC (GROUND-WATER REMEDIATION TECHNOLOGIES ANALYSIS CENTER). Remediation of Metals-Contaminated Soils and Groundwater. Technology Evaluation Report TE-97-01, pág. 1-29, 1997.

JENSEN, P. E.; OTTOSEN, L. M.; PEDERSEN, N. J. Speciation of Pb in Industrially Polluted Soils. Water, Air and Soil Pollution 170, pág. 359-382, 2006.

KERSTEN, M.; FÖRSTNER, U. Speciation of Trace Elements in Sediments. In: BATley, G. E. (Ed.). Trace Element Speciation: Analytical Methods and Problems, pág. 245-317. CRC Press, 1990.

KREBS, W.; BROMBACHER, C.; BOSSHARD, P. P.; BACHOFEN, R.; BRANDL, H. Microbial Recovery of Metal from Solids. Federation of European Microbiological Societies, FEMS Microbiology Reviews 20, pág. 605-617, 1997.

LABUnSKA, I.; STRINGER, R.; BRIDGEN, K. Poluição por Metais e Compostos Orgânicos Associada à Unidade da Bayer em Belford Roxo, Rio de Janeiro, Brasil. Nota Técnica 23/00, Greenpeace, 2000.

LLOYD, J. R. Bioremediation of Metals; The Application of Micro-Organisms that Make and Break Minerals. Microbiology Today, volume 29, pág. 67-69, maio 2002. 
MERCIER, G.; DUCHESNE, J.; CARLES-GIBERGUES, A. A Simple and Fast Screening Test to Detect Soil Polluted by Lead. Environmental Pollution, 118, pág. 285-296, 2002.

MORITA, D. M.; CASARINI, D. C. P.; BEVILACQUA, J. E.; ROCCO, J. L. S.; COLABONE, A. J.; ROCCA, A. C. C. Plano de Intervenção da Região dos Lagos de Santa Gertrudes. In: SECRETARIA DE ESTADO DO MEIO AMBIENTE. Resolução SMA no 2, de 20/02/01 que "Institui Grupo de Trabalho do Projeto Corumbataí Cerâmicas e dá Outras Providências”. Processo SMA n 50/2001. Volume 1/3.

MOURA, A. N.; MORITA, D. M.; BOSCOV, M. E. G.; RIVERA, I. N. G.; OliveIRA, E.; QUINAGLIA, G. A. Solicitação de Financiamento para Realização de Pesquisa de Doutorado Intitulada Remediação de Áreas Contaminadas com Metais Pesados Utilizando Acidithiobacillus sp. Processo FAPESP n 04/08039-4, 2004.

MUlligAN, C. N.; YONG, R. N.; GIBBS, B. F. Removal of Heavy Metals from Contaminated Soil and Sediments Using the Biosurfactant Surfactin. Journal of Soil Contamination, 8(2), pág. 231-254, 1999.

NOGAMI, J. S. Pavimentação de Baixo Custo com Solos Lateríticos. Vilibor, São Paulo, pág. 5-41, 1995.

OHMURA, N.; SASAKI, K.; MATSUMOTO, N.; SAIKI, H. Anaerobic Respiration Using $\mathrm{Fe}^{3+}, \mathrm{S}_{0}$ and $\mathrm{H}_{2}$ in the Chemolithoautotrophic Bacterium Acidithiobacillus ferrooxidans. Journal of Bacteriology, American Society for Microbiology, volume 184, nº 8, pág. 2.081-2.087, abril 2002.

PIGMENTOS SEGUNDO OS ELEMENTOS QUÍMICOS. Acesso on line em 12/05/2004: http://ciarte.no.sapo.pt/material/pigmento/pig_elem.htm.

PICHTEL, J.; PICHTEL, T. M. Comparison of Solvents for Ex situ Removal of Chromium and Lead from Contaminated soil. Environmental Engineering Science, v. 14, n. 2, p. 97-104, 1997. 
PICHTEL, J.; VINE, B.; KUULA-VÄISÄNEN, P.; NISKANEN, P. Lead Extration from Soils as Affected by Lead Chemical and Mineral forms. Environmental Engineering Science, v.18, n. 2, p. 91-8, 2001.

PROJETO DE PREVENÇÃO À POLUIÇÃO EM INDÚSTRIAS DE PISOS E REVESTIMENTOS CERÂMICOS. Acesso on line em 26/08/2004: http://www.cetesb.sp.gov.br/Ambiente/prevencao_poluicao/documentos.asp.

REED, B. E.; CARRIERE, P. C.; MOORE, R. Flushing of a Pb(II) Contaminated Soil Using $\mathbf{H C l}$, EDTA, and $\mathbf{C a C l}_{2}$. Journal of Environmental Engineering, American Society Civil Engineers, v. 122, n. 1, p. 48-50, 1996

RULKENS, W. H.; GROTENHUIS, J. T. C.; TICHÝ, R. Methods for Cleaning Contaminated Soils and Sediments. In: SALOMONS, W.; FÖRSTNER, U.; MADER, P. (Eds.). Heavy Metals Problems and Solutions, pág. 165-186. Springer-Verlag Berlin Heidelberg, 1995.

SILVA, A. L. B. Caracterização Ambiental e Estudo do Comportamento do Chumbo, Zinco e Boro em Área Degradada por Indústrias Cerâmicas - Região dos Lagos de Santa Gertrudes, SP. 2.001. 229p. Dissertação (Mestrado), Instituto de Geociências, Universidade de São Paulo, 2001.

SILVA, S. M. C. P.; FERNANDES F.; SOCCOL, V. T.; MORITA, D. M. Principais Contaminantes do Lodo. In: ANDREOLI, C. V.; VON SPERLING, M.; FERNANDES, F. Princípios do Tratamento Biológico de Águas Residuárias, Lodo de esgotos: tratamento e disposição final. Volume 6. Departamento de Engenharia Sanitária e Ambiental - UFMG. Companhia de Saneamento do Paraná, 2001 .

STEELE, M. C.; PICHTEL, J. Ex-Situ Remediation of a Metal-Contaminated Superfund Soil Using Selective Extractants. Journal of Environmental Engineering. American Society Civil Engineers, v. 124, n. 7, p. 639-45, 1998.

TAKAMATSU, A. A. Avaliação da Biolixiviação de Metais Pesados por Bactérias do Gênero Thiobacillus em Lodos Biológicos para Utilização Agrícola 
como Fertilizante. 1.995. 93p. Dissertação (Mestrado), Setor de Ciências Agrárias, Universidade Federal do Paraná. Curitiba, 1995.

TURICK, C. E.; GRAVES, C.; APEL, W. A. Bioremediation Potencial of Cr(VI) Contaminated Soil Using Indigenous Microorganisms. Bioremediation Journal, Volume 2(1), pág. 1-6, 1998.

UNIVERSIDADE DE BRASÍLIA. INSTITUTO DE GEOCIÊNCIAS. DEPARTAMENTO DE MINERALOGIA E PETROLOGIA. Fundamentos de Mineralogia - Óxidos e Hidróxidos. Acesso on line em 11/10/2006: http://www.unb.br/ig/cursos/FundMineral/FundMineral_Apostila5.pdf

US DEPARTMENT OF HEALTH AND HUMAN SERVICES. PUBLIC HEALTH SERVICE. AGENCY FOR TOXIC SUBSTANCES AND DISEASE REGISTRY (ATSDR). Toxicological Profile for Silver, 1990.

. Toxicological Profile for Cadmium, 1999.

. Toxicological Profile for Mercury, 1999.

. Toxicological Profile for Chromium, 2000.

. Toxicological Profile for Cooper, 2002.

. Toxicological Profile for Nickel, 2003.

Toxicological Profile for Zinc, 2003.

USEPA (UNITED STATES ENVIRONMENTAL PROTECTION AGENCY). Acid Digestion of Sediments, Sludges and Soils - Método 3050B, 1996.

. Inorganics by ICP - Atomic Emission Spectroscopy - Método 6010B, 1996.

. Recent Developments for In Situ Treatment of Metal Contaminated Soils. Appendix B, pág. B3-B4, 1997. 
WASAY, S. A.; BARRINGTON, S. F.; TOKUNAGA, S. Using Aspergillus niger to Bioremediate Soils Contaminated by Heavy Metals. Bioremediation Journal, Volume 2(3), pág. 183-190, 1998. 